\begin{abstract}
UNIVERSIDADE DE SÃO PAULO
FACULDADE DE ODONTOLOGIA DE RIBEIRÃO PRETO DEPARTAMENTO DE CLÍNICA INFANTIL

PROGRAMA DE PÓS-GRADUAÇÃO EM ODONTOPEDIATRIA
\end{abstract}

\author{
PATRícIa MARIA MONTEIRO
}

Efeito da Inalação de FumaÇa de CigarRo no Processo de Remodelação Óssea aPós EXPANSÃo RÁPIDA DA MAXILA 

Patrícia Maria Monteiro

\title{
Efeito da InALAÇÃo de FumaÇA de CigarRo No Processo de Remodelação Óssea APÓS EXPANSÃO RÁPIDA DA MAXILA
}

\author{
Tese apresentada à Faculdade de Odontologia de \\ Ribeirão Preto da Universidade de São Paulo, para \\ obtenção do Título de Doutora em Ciências. \\ Área de concentração: Odontopediatria \\ Orientadora: Prof $^{\text {a. }}$ Dr $^{\text {a. }}$ Maria Bernadete Sasso Stuani
}

RIBEIRÃO PRETO 
AUTORIZO A REPRODUÇÃO E DIVULGAÇÃO TOTAL OU PARCIAL DESTE TRABALHO, POR QUALQUER MEIO CONVENCIONAL OU ELETRÔNICO, PARA FINS DE ESTUDO E PESQUISA, DESDE QUE CITADA A FONTE.

FICHA CATALOGRÁFICA

Monteiro, Patrícia Maria

Efeito da inalação de fumaça de cigarro no processo de remodelação óssea após expansão rápida da maxila, 2017.

122p. : il. ; $30 \mathrm{~cm}$

Tese de Doutorado, apresentada à Faculdade de Odontologia de Ribeirão Preto da Universidade de São Paulo. Área de concentração: Odontopediatria.

Orientadora: Stuani, Maria Bernadete Sasso.

1. Fumaça de cigarro. 2. Força ortopédica. 3. Expansão rápida da maxila. 4. Remodelação óssea. 5. Reparo ósseo 


\section{FOLHA DE APROVAÇÃO}

Monteiro, PM. Efeito da inalação de fumaça de cigarro no processo de remodelação óssea após expansão rápida da maxila. Tese apresentada à Faculdade de Odontologia de Ribeirão Preto da Universidade de São Paulo, para obtenção do Título de Doutora em Ciências. Área de Concentração: Odontopediatria.

Data da defesa:

\section{Banca Examinadora}

Prof. Dr.

Instituição:

Julgamento:

Assinatura:

Prof. Dr.

Instituição:

Julgamento:

Assinatura:

Prof. Dr.

Instituição:

Julgamento:

Assinatura:

Prof. Dr.

Instituição:

Julgamento:

Assinatura:

Prof. Dr.

Instituição:

Julgamento:

Assinatura: 



\section{DADOS CURRICULARES}

\section{PATRÍCIA MARIA MONTEIRO}

Nascimento 07 de agosto de 1983, Ribeirão Preto, SP

Filiação Helena da Conceição Bigi Monteiro

Wladimir Hiesinger Monteiro

2001-2004 Graduação em Odontologia

Faculdade de Odontologia de Ribeirão Preto da Universidade de São Paulo

Iniciação Científica: Avaliação de um possível ritmo circadiano de atividade do Locus Coeruleus de ratas.

Orientadora: Prof ${ }^{\mathrm{a} .} \mathrm{Dr}^{\mathrm{a} .}$ Janete Aparecida Anselmo Franci

Bolsa: FAPESP

2005-2007 Mestrado em Odontopediatria

Faculdade de Odontologia de Ribeirão Preto da Universidade de São Paulo

Dissertação: Avaliação eletromiográfica dos músculos masseter e temporal e cefalometria em norma lateral de crianças submetidas a expansão maxilar com o aparelho quadri-hélice.

Orientadora: Prof ${ }^{\mathrm{a} .} \mathrm{Dr}^{\mathrm{a}}$. Maria Bernadete Sasso Stuani

Bolsa: CAPES

2008-2011

Curso de Especialização em Ortodontia

Faculdade de Odontologia de Araraquara da Universidade Estadual Paulista "Júlio de Mesquita Filho"

Monografia: Aplicações clínicas do sistema Invisalign ${ }^{\oplus}$ na ortodontia.

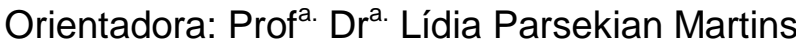

2013-2017 Doutorado em Ciências

Faculdade de Odontologia de Ribeirão Preto da Universidade de São Paulo

Tese: Efeito da inalação de fumaça de cigarro no processo de remodelação óssea após expansão rápida da maxila.

Orientadora: Prof ${ }^{\text {a. }}$ Dr $^{\text {a. }}$ Maria Bernadete Sasso Stuani

Bolsa: CAPES 



\section{DEDICO ESTE TRABALHO}

À minha estrelinha Ana Flávia, por ter me ensinado tanto em tão pouco tempo. Vou te carregar para sempre em meu coração, minha filha!!

Aos meus pais Wladimir e Helena, por sempre acreditarem e incentivarem meu progresso moral e intelectual. Por todo o amor e cuidado compartilhados nesta e em tantas outras existências... que nos sejam permitidas muitas mais!! Imensurável gratidão!!

Aos meus irmãos Guilherme, Thẩs e Tăssia, por viverem comigo as minhas alegrias e as minhas dores. Por estarem sempre por perto e me fortalecerem nos momentos de dúvida... muito amor e gratidão!!!

Aos meus cunhados Aline, Fábio e Alexandre, por compartilharem tantos momentos e sentimentos. Vocês são como irmãos para mim!!!

Aos meus sobrinhos Felipe e Júlia, por cobrirem meus dias de alegria e de fofura!!! Vocês representam a esperança de um futuro melhor!!!

Ao Francisco, por caminhar boa parte desta jornada ao meu lado. Por todo apoio e incentivo, especialmente nos experimentos de fim de semana. 



\section{AGRADECIMENTOS ESPECIAIS}

À minha orientadora Bernadete, por todo apoio e empenho na condução deste trabalho. Por exercer com tanto amor e dedicação a arte de ensinar, incentivandonos a prezar pela amizade e humanidade na busca pelo aperfeiçoamento profissional. Você é um exemplo e uma inspiração para mim!!!

Aos meus companheiros de pesquisa Larissa, Kelly, Gabriel, Elaine e Paula, por compartilharem comigo muito mais do que experimentos e técnicas. Pelos sorrisos, pelas palavras de motivação, pelo carinho e pelos cuidados. Sou muito feliz e grata por fazer parte deste time de "orientados da Berna"!!!!

A Maya e Maria Cecilia (Ciça), amigas queridas e tão próximas do meu coração. Obrigada pelas demonstrações constantes de carinho!!! 



\section{AGRADECIMENTOS}

À Faculdade de Odontologia de Ribeirão Preto da Universidade de São Paulo, na pessoa da atual Diretora Profa. Dra. Léa Assed Bezerra da Silva e do Vice-Diretor Prof. Dr. Arthur Belém Novaes Jünior.

À Coordenação do Curso de Pós-Graduação da Faculdade de Odontologia de Ribeirão Preto da Universidade de São Paulo, na pessoa do Prof. Dr. Manoel Damião de Sousa Neto.

Aos Professores do Departamento de Clínica Infantil da Faculdade de Odontologia de Ribeirão Preto da Universidade de São Paulo, Prof. Dr. Adilson Tomasin Profa. Dra. Aldevina Campos Freitas, Profa. Dra. Alexandra Mussolino de Queiroz, Profa. Dra. Andiara De Rossi Daldegan, Prof. Dr. Fábio Lourenço Romano, Prof. Dr. Fabricio Kitazono de Carvalho, Prof. Dr. José Tarcísio Lima Ferreira, Profa. Dra. Kranya Victoria Díaz Serrano, Profa. Dra. Léa Assed Bezerra da Silva, Profa. Dra. Maria da Conceição Pereira Saraiva, Profa. Dra. Maria Cristina Borsatto, Profa. Dra. Mírian Aiko Nakane Matsumoto, Prof. Dr. Paulo Nelson Filho e Profa. Dra. Raquel Assed Bezerra Segato, aos Professores do Departamento de Morfologia, Estomatologia e Fisiologia da Faculdade de Odontologia de Ribeirão Preto da Universidade de São Paulo Profa. Dra. Mamie Mizusaki lyomasa e Prof. Dr. João Paulo Madergan Issa e à Professora do Departamento de Análises Clínicas, Toxicológicas e Bromatológicas da Faculdade de Ciências Farmacêuticas de Ribeirão Preto da Universidade de São Paulo Profa. Dra. Sandra Yasuyo Fukada Alves.

À Carolina Maschietto Pucinelli, Daniele Longo, Erika Calvano Kuchler, Francine Lorencetti da Silva, Francisco Wanderley Garcia de Paula e Silva e Marillia Pacífico Lucisano pela amizade, pelas boas conversas e por tornarem estes momentos especiais. Vocês fizeram diferença neste meu curso de doutorado! 
Aos demais pós-graduandos do Programa de Pós-Graduação em Odontopediatria pelas conversas e convivência agradável.

À Michelli Cristina Leite Rovanholo e Filomena Leli Placciti pela amizade, ajuda constante, paciência e descontração!!! Muito obrigada por estarem sempre por perto nesta minha caminhada!

Aos funcionários do Departamento de Clínica Infantil da Faculdade de Odontologia de Ribeirão Preto da Universidade de São Paulo, Fátima Aparecida Jacinto Daniel, Matheus Morelli Zanela, Nilza Leticia Magalhães, Marco Antônio dos Santos e Sr. Carmo Euripedes Terra Barretto e aos funcionários do Centro de Formação de Recursos Humanos no Atendimento Odontológico a Pacientes Especiais Carolina Paes Torres Mantovani, Fátima Aparecida Rizoli e Benedita Viana Rodrigues pela amizade e atenção que sempre manifestaram!

Aos funcionários do Biotério da Faculdade de Odontologia de Ribeirão Preto da Universidade de São Paulo, Aline Aparecida Ferraresi Tiballi, Antonio Sérgio Aparecido Mesca e Antônio Masssaro pela amizade, boa convivência, ajuda, disponibilidade e pelos cuidados prestados aos animais durante todo o período experimental desta pesquisa. Vocês foram muito importantes para o andamento desta minha pesquisa!

Aos funcionários da Seção de Pós-Graduação da Faculdade de Odontologia de Ribeirão Preto da Universidade de São Paulo, Mary Possani Carmessano e Carlos Feitosa dos Santos pela cordialidade e atenção.

À Rosemary Alves de Sá, pela atenção e sorriso com que sempre me recebe!! Obrigada pela valiosa ajuda nessa reta final.

À Capes (Coordenação de Aperfeiçoamento de Pessoal de Nivel Superior) e FAPESP (Fundação de Amparo e Apoio à Pesquisa do Estado de São Paulo), pelo suporte técnico, científico e financeiro fundamentais para a realização deste trabalho. 


\section{RESUMO}

Monteiro PM. Efeito da inalação de fumaça de cigarro no processo de remodelação óssea após expansão rápida da maxila. [Tese]. Ribeirão Preto: Faculdade de Odontologia de Ribeirão Preto da Universidade de São Paulo; 2017.

Introdução: O hábito de fumar é bastante comum e, na maioria das vezes, iniciase ainda na adolescência. Dentre as diversas alterações sistêmicas provocadas, o comprometimento do processo de reparo celular é de grande importância na compreensão dos movimentos dento-esqueléticos. Não existem evidências científicas que correlacionem este hábito e suas influências no tratamento ortodôntico/ortopédico, especialmente no tocante às análises celulares e moleculares. Objetivo: $O$ objetivo deste estudo foi avaliar o processo de remodelação óssea após aplicação de forças ortopédicas em ratos fumantes. Material e Métodos: Um total de 120 ratos Wistar foram divididos em 4 grupos: controle negativo [sutura intacta, sem fumaça de cigarro (FC)], grupo experimental I (sutura intacta e com FC), grupo experimental II [expansão rápida da maxila (ERM) e sem FC] e grupo experimental III $(E R M+F C)$. Cada grupo foi subdividido em 4 períodos experimentais de avaliação $(n=5)$ sendo os animais de cada subgrupo submetidos à eutanásia após 3, 7, 14 e 21 dias após a expansão maxilar ortopédica. Foram avaliadas as mudanças na expressão gênica de Rank, Rankl, osteoprotegerina $(O p g)$, osteonectina $(O n c)$, osteocalcina $(O c c)$, sialoproteína óssea $(B s p)$, osteopontina $(O p n)$ e proteína morfogenética óssea $(B m p-2)$ por meio de qRT-PCR. Estes dados foram confirmados pela avaliação histológica dos grupos nos períodos de 7 e 21 dias. Os resultados foram agrupados de acordo com os diferentes grupos de estudo e de período experimental, submetidos à Anova (one-way/two-way) seguidos pelo pós-teste de Tukey e Bonferroni $(p<0,05)$. Resultados: Houve estímulo à osteoclastogênese nos grupos submetidos à ERM, com menor magnitude naquele que também foi exposto à fumaça de cigarro. Os marcadores de osteogênese foram estimulados apenas nos animais submetidos à ERM, durante todos os períodos avaliados. Estes resultados foram confirmados nos achados histológicos, tendo em vista que a ERM resultou em intensa remodelação óssea na sutura palatina, caracterizada por tecido desorganizado com intensas areas inflamatórias, hemorrágicas e reabsortivas em períodos iniciais, seguida por tecido ósseo neo-formado bastante celularizado com numerosos vasos sanguíneos, fibroblastos e osteoblastos em fase tardia de reparo. A inalação de fumaça de cigarro exacerbou e prolongou os eventos inflamatórios após ERM, com presença de tecido desorganizado e atividade osteoclástica persistente em períodos mais tardios do reparo. Conclusão: A exposição à fumaça de cigarro associada à expansão rápida da maxila prejudicou o processo de reparo ósseo nos diferentes tempos analisados, tornando-o mais lento e desorganizado.

Palavras-chave: fumaça de cigarro, força ortopédica, expansão rápida da maxila, remodelação óssea, reparo ósseo. 



\begin{abstract}
Monteiro PM. Effect of cigarette smoke inhalation on bone remodeling process after rapid maxillary expansion. [Thesis]. Ribeirão Preto: School of Dentistry of Ribeirão Preto at University of São Paulo; 2017.
\end{abstract}

Background: Smoking habit is very common and, in most of the times, it begins early during adolescence. Among all the systemic alterations it causes, damage on cellular repair process is of great importance to understanding dental-skeletic movement. However, there is no scientific evidences related to this issue, orthodontic/orthopedic treatment and celular and biomolecular evaluations. Objective: The aim of this study was to evaluate the bone remodeling process during orthopedic mecanotherapy in rats submitted to cigarette smoke inhalation. Material and Methods: One hundred and twenty Wistar male rats were randomly divided into four study groups: control group [intact midpalatal suture and no cigarette smoke (CS)], experimental group I (intact midpalatal suture and CS), experimental group II [rapid maxillary expansion (RME) and no CS] and experimental group III (RME+CS). Each group was subdivided into 4 experimental periods of evaluation $(n=5)$ and the animals of these subgroups were euthanized at $3,7,14$ and 21 days after orthopedic treatment. Changes in gens expression of Rank, Rankl, osteoprotegerin (Opg), osteonectin (Onc), osteocalcin (Occ), bone sialoprotein (Bsp), osteopontin (Opn) and bone morphognetic protein (Bmp2) were evaluated with qRT-PCR. These data were confirmed by histologic evaluations of animal groups after 7 and 21 days of healing. The results were clustered according to the different study groups and the period of healing and were analyzed using Anova (one-way/two-way) with Tukey and Bonferroni post-test $(p<0,05)$. Results: There was an upregulation of osteoclastogenesis on groups submitted to RME, with less magnitude on the $\mathrm{RME}+\mathrm{CS}$ group. Osteogenesis biomarkers were upregulated only on animals submitted to RME, during all evaluated periods. These results were confirmed by histological findings, considering that RME led to intense bone remodeling on midpalatal suture, characterized by desorganized tissue with inflammatory, hemorhagic and resorptive areas in early period of healing, followed by new-formed bone plenty of cells and numerous blood vessels, fibroblasts and osteoblasts in late periods. Cigarette smoke inhalation increased and extended inflammatory events after RME, with desorganized tissue and osteoclastic activity persistent until late periods of bone healing. Conclusion: Cigarette smoke exposure associated with RME impaired bone remodeling process on different evaluated periods, making it slower and more disorderly.

Key-words: cigarette smoke, orthopedic forces, rapid maxillary expansion, bone remodeling, bone repair. 



\section{LISTA DE FIGURAS}

Figura 1. Vista oclusal durante instalação de dispositivo ortodôntico entre os incisivos centrais

Figura 2. Desenho esquemático representando o mecanismo de exposição à fumaça. Observa-se a câmara 1 onde os cigarros foram posicionados e a câmara 2, onde os animais permaneceram durante a exposição à fumaça de cigarro.

Figura 3. Câmara de exposição à fumaça de cigarro

Figura 4. A: Radiografia da sutura palatina mediana intacta. B: Radiografia de confirmação da abertura da sutura palatina mediana após ERM.

Figura 5. Região da sutura palatina mediana do grupo controle 7 dias corte frontal (A) e longitudinal (B, C, D), onde observa-se: A) visão panorâmica da sutura palatina mediana mostrando tecido conjuntivo sutural (TC) delimitado por tecido ósseo (O). B), C) e D) detalhe da sutura onde é possível verificar osso $(0)$ recoberto por osteoblastos delimitando a superfície óssea (setas pretas), fibras colágenas inseridas no tecido ósseo (FC) e vasos sanguíneos (V) por toda extensão do tecido sutural. Coloração H/E e Tricrômico de Masson.....

Figura 6. Região da sutura palatina mediana do grupo controle 21 dias cortes longitudinais (A, B, C, D), onde observa-se: A) visão panorâmica da sutura palatina mediana mostrando tecido conjuntivo sutural (TC) delimitado por tecido ósseo (O) e (D) dente. B), C) e D) detalhe da sutura onde é possível verificar osso (0) recoberto por osteoblastos delimitando a superfície óssea (setas pretas), fibras colágenas inseridas no tecido ósseo (FC) e vasos sanguíneos (V) por toda extensão do tecido sutural. Coloração $H / E$.

Figura 7. Região da sutura palatina mediana do grupo FC 7 dias corte frontal (A) e longitudinal (B, C, D), onde observa-se: A) visão panorâmica mostrando a sutura palatina mediana com tecido conjuntivo sutural (TC) delimitado por tecido ósseo (O). B), C) e D) detalhe da sutura onde é possível verificar osso (0) recoberto por osteoblastos delimitando a superfície óssea, (TC) tecido conjuntivo com numerosos fibroblastos e vasos sanguíneos (V) por toda extensão do tecido sutural. Coloração H/E e Tricrômico de Masson. 
Figura 8. Região da sutura palatina mediana do grupo FC 21 dias corte frontal (A) e longitudinal (B, C, D), onde observa-se: A) visão panorâmica mostrando a sutura palatina mediana mostrando tecido conjuntivo sutural (TC) delimitado por tecido ósseo (O). B), C) e D) detalhe da sutura onde é possível verificar osso (O) recoberto por osteoblastos delimitando a superfície óssea (setas pretas), fibras colágenas inseridas no tecido ósseo (FC) e vasos sanguíneos (V) por toda extensão do tecido sutural. Coloração $H / E$ e Tricrômico de Masson.....

Figura 9. Região da sutura palatina mediana do grupo ERM 7 dias cortes longitudinais (A, B, C, D), onde observa-se: A) visão panorâmica da sutura palatina mediana mostrando tecido conjuntivo sutural com algumas áreas inflamatórias presentes no tecido conjuntivo (TC) delimitado por tecido ósseo (O) e (D) dente. B), C) e D) Detalhe da sutura onde é possível verificar osso imaturo com contorno irregular (O) recoberto por osteoblastos ativos delimitando a superfície óssea (setas pretas). Coloração H/E e Tricrômico de Masson..................

Figura 10. Região da sutura palatina mediana do grupo ERM+FC 7 dias cortes longitudinais (A, B, C, D), onde observa-se: A) visão panorâmica da sutura palatina mediana mostrando tecido conjuntivo sutural com áreas hemorrágicas (*)no tecido conjuntivo (TC) delimitado por tecido ósseo (O) e (D) dente. B), C) e D) Detalhe da sutura onde é possível verificar osso (O) recoberto por osteoblastos delimitando a superfície óssea (setas pretas), áreas hemorrágicas $\left(^{\star}\right)$ e inflamação (I) por toda extensão do tecido sutural. Proliferação vascular (V) estava presente. Coloração Tricrômico de Masson.

Figura 11. Região da sutura palatina mediana do grupo ERM 21 dias cortes longitudinais (A, B, C, D), onde observa-se: A) visão panorâmica da sutura palatina mediana mostrando tecido conjuntivo sutural (TC) delimitado por tecido ósseo (O) e (D) dente. B), C) e D) Detalhe da sutura onde é possível verificar osso (O) recoberto por osteoblastos delimitando a superfície óssea (setas pretas), fibras colágenas inseridas no tecido ósseo (FC) e vasos sanguíneos (V) por toda extensão do tecido sutural. Coloração H/E e Tricrômico de Masson

Figura 12. Região da sutura palatina mediana do grupo ERM+FC 21 dias corte frontal (A), e cortes longitudinais B, C, D), onde observa-se: A) visão panorâmica da sutura palatina mediana mostrando tecido conjuntivo sutural (TC) delimitado por tecido ósseo (O) e (D) dente. B), C) e D) Detalhe da sutura onde é possível verificar trabéculas de tecido ósseo (O) espalhadas no tecido conjuntivo (FC) e vasos sanguíneos (V) por toda extensão do tecido sutural. Coloração H/E e Tricrômico de Masson. 
Figura 13. (A) Expressão do RNAm do gene Tnfrs11a (Rank) nos diferentes grupos em comparação ao grupo controle e (B) Comparação entre os dois grupos experimentais. Os gráficos mostram média, desvio padrão. ${ }^{*} p<0,05$, ${ }^{* *} p<0,01 .{ }^{* * *} p<0,001$.

Figura 14. (A) Expressão do RNAm do gene Tnfrs11 (Rankl) nos diferentes grupos em comparação ao grupo controle e (B) Comparação entre os dois grupos experimentais. Os gráficos mostram média, desvio padrão. ${ }^{*} \mathrm{p}<0,05$, ${ }^{* *} \mathrm{p}<0,01 .{ }^{* * *} \mathrm{p}<0,001$

Figura 15. (A) Expressão do RNAm do gene Tnfrsf11b (Opg) nos diferentes grupos em comparação ao grupo controle e (B) Comparação entre os dois grupos experimentais. Os gráficos mostram média, desvio padrão. ${ }^{*} p<0,05$, ${ }^{* *} \mathrm{p}<0,01 .{ }^{* * *} \mathrm{p}<0,001$

Figura 16. (A) Expressão do RNAm do gene Bmp-2 nos diferentes grupos em comparação ao grupo controle e (B) Comparação entre os dois grupos experimentais. Os gráficos mostram média, desvio padrão. * $p<0,05$, ${ }^{* *} \mathrm{p}<0,01 .{ }^{* * *} \mathrm{p}<0,001$

Figura 17. (A) Expressão do RNAm do gene Ibsp (Bsp) nos diferentes grupos em comparação ao grupo controle e (B) Comparação entre os dois grupos experimentais. Os gráficos mostram média, desvio padrão. ${ }^{*} \mathrm{p}<0,05$, ${ }^{* *} p<0,01 .{ }^{* * *} p<0,001$.

Figura 18. (A) Expressão do RNAm do gene Sparc (Onc) nos diferentes grupos em comparação ao grupo controle e (B) Comparação entre os dois grupos experimentais. Os gráficos mostram média, desvio padrão. ${ }^{*} \mathrm{p}<0,05$, ${ }^{* *} \mathrm{p}<0,01 .{ }^{* * *} \mathrm{p}<0,001$

Figura 19. (A) Expressão do RNAm do gene Bglap (Occ) nos diferentes grupos em comparação ao grupo controle e (B) Comparação entre os dois grupos experimentais. Os gráficos mostram média, desvio padrão. ${ }^{*} \mathrm{p}<0,05$, ${ }^{* *} p<0,01 .{ }^{* * *} p<0,001$.

Figura 20. (A) Expressão do RNAm do gene Spp1 (Opn) nos diferentes grupos em comparação ao grupo controle e (B) Comparação entre os dois grupos experimentais. Os gráficos mostram média, desvio padrão. ${ }^{*} p<0,05$, ${ }^{* *} \mathrm{p}<0,01 .{ }^{* * *} \mathrm{p}<0,001$ 



\section{LISTA DE ABREVIATURAS, SIGLAS E SÍMBOLOS}

ANOVA: $\quad$ Análise de Variância

Bglap: $\quad$ gene referente à expressão de osteocalcina (OCC)

Bmp2: $\quad$ gene referente à expressão de proteína óssea morfogenética 2 (BMP-2)

BMP-2: $\quad$ proteína óssea morfogenética 2

BSP: $\quad$ sialoproteína óssea

cDNA: ácido desoxirribonucleico complementar

CEUA: Comissão de Ética no Uso de Animais

$\mathbf{c m}^{3}$ : $\quad$ centímetros cúbicos

$\mathbf{C}_{\mathrm{T}}$ : $\quad$ Ciclo de amplificação (cycle threshold)

${ }^{\circ} \mathbf{C :} \quad$ graus Celsius

$\Delta: \quad$ delta

$\Delta \mathbf{C}_{\mathrm{T}}: \quad$ diferença entre $\mathrm{C}_{\mathrm{T}}$ da amostra amplificada para o gene alvo e o $\mathrm{C}_{\mathrm{T}}$ da mesma amostra amplificada para o gene de referência

$\Delta \boldsymbol{\Delta C}_{\mathrm{T}}: \quad$ diferença entre o $\Delta \mathrm{C}_{\mathrm{T}}$ da amostra interesse e $\circ \Delta \mathrm{C}_{\mathrm{T}}$ da amostra de referência-calibrador

DEPC: dietilpirocarbonato

DNA: ácido desoxirribonucleico

EDTA: etileno-diamino-tetra-acético

ERM: $\quad$ expansão rápida da maxila

FC: fumaça de cigarro

FORP: $\quad$ Faculdade de Odontologia de Ribeirão Preto

g: $\quad \operatorname{grama}(\mathrm{s})$

GAPDH: $\quad$ gliceraldeído-3-fosfato desidrogenase

HE: hematoxilina e eosina

Ibsp: $\quad$ gene referente à expressão de sialoproteína óssea (BSP)

$\mathrm{Kg}$ : $\quad$ quilograma(s)

kV: $\quad$ quilovolt(s)

$\mu \mathrm{L}: \quad$ microlitro(s)

um: $\quad$ micrômetro(s)

mA: $\quad$ miliampere(s)

mg: $\quad$ miligrama(s)

$\mathrm{mL}$ : mililitro(s) 


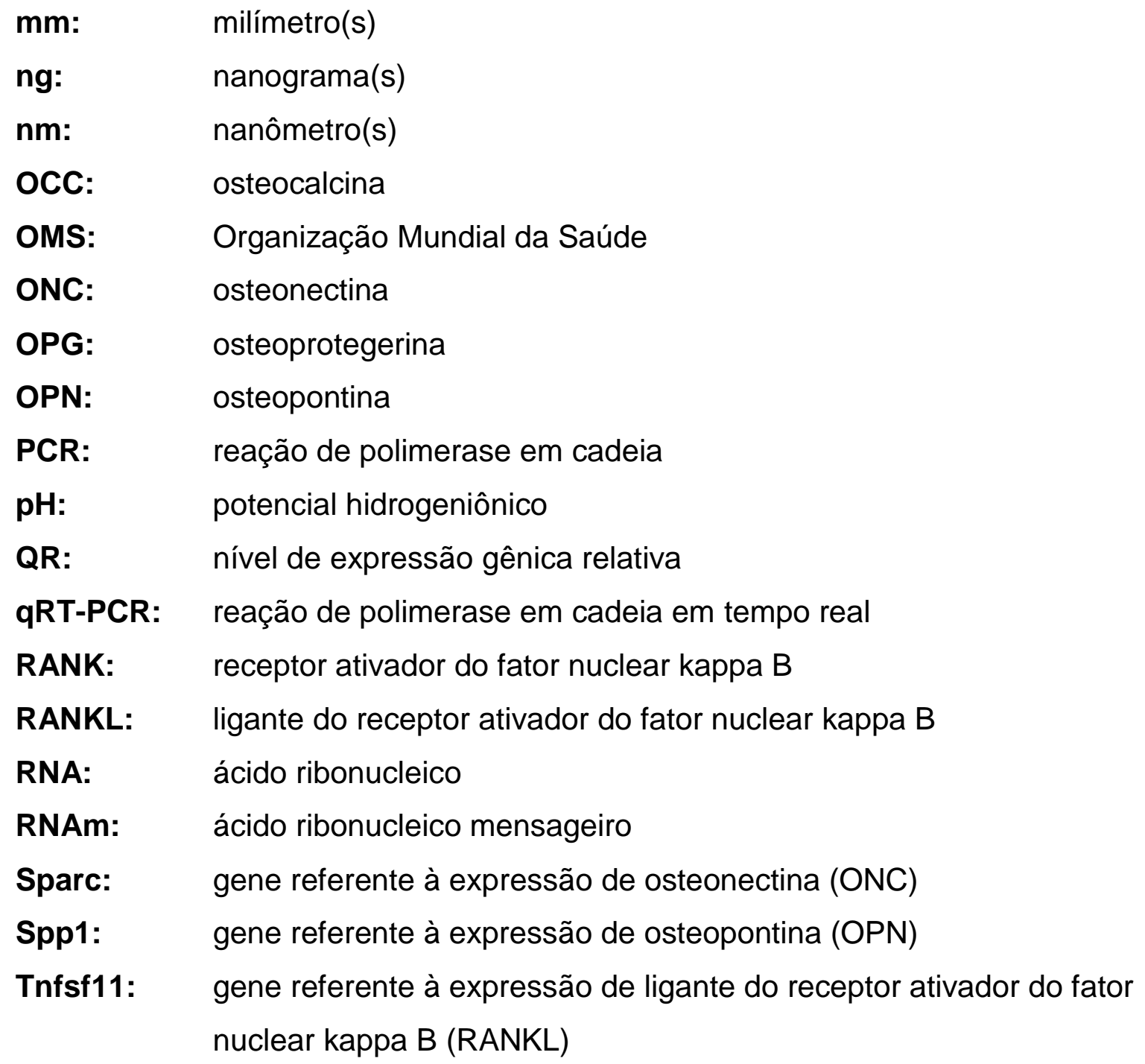

Tnfrsf11a: gene referente à expressão de receptor ativador do fator nuclear kappa

Tnfrsf11b: B (RANK)

v/v: $\quad$ gene referente à expressão de osteoprotegerina (OPG) porcentagem em volume (volume/volume) 


\section{SUMÁRIO}

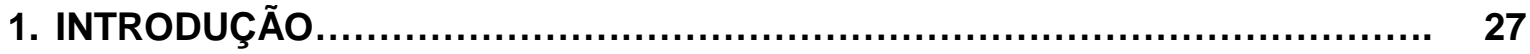

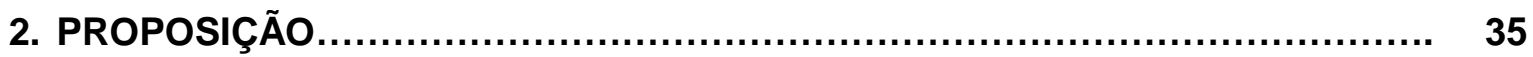

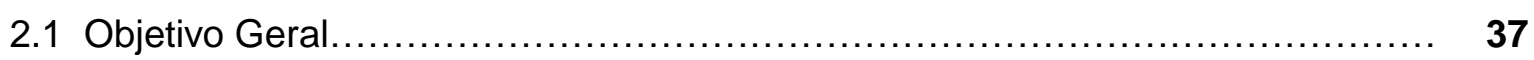

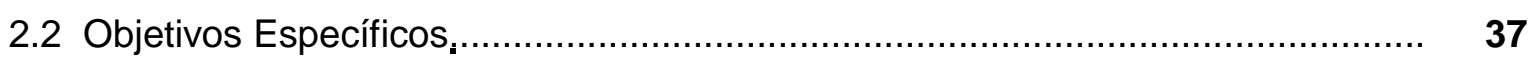

3. MATERIAL E MÉTODOS.............................................................. 39

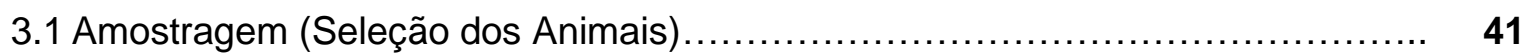

3.2 Delineamento Experimental.......................................................................... 41

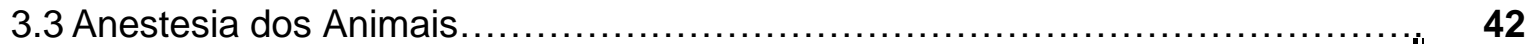

3.4 Instalação e Ativação do Dispositivo Ortodôntico para a Disjunção da Sutura

Palatina Mediana..................................................................................................... 42

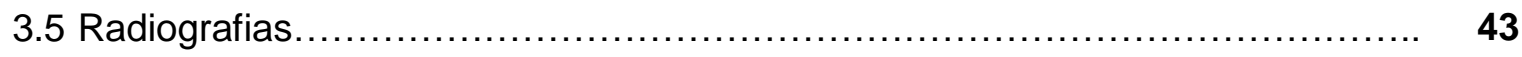

3.6 Exposição à fumaça de cigarro................................................................. 44

3.7 Eutanásia dos animais, coleta e preparo dos espécimes.................................. 46

3.8 Análise da expressão gênica.............................................. 46

3.8.1 Isolamento e avaliação do RNA total (Extração de RNA) .......................... 46

3.8.2 Síntese do DNA complementar (cDNA)............................................... 47

3.8.3 Reação em Cadeia da Polimerase (PCR) após Transcrição Reversa ou PCR em tempo real (qRT-PCR) .............................................................. 47

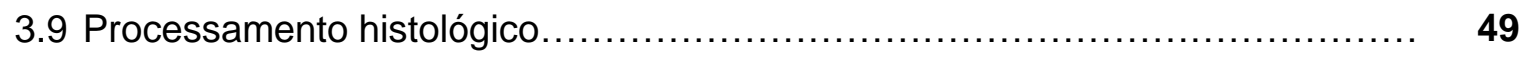

3.10 Análise dos resultados..................................................................... 51

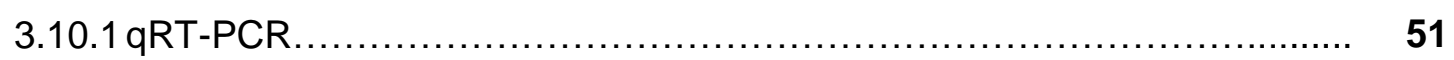

3.10.2 Avaliação histológica............................................................... 52

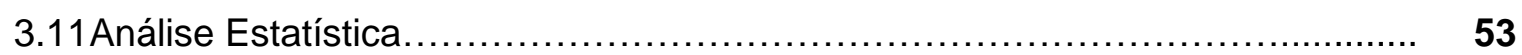

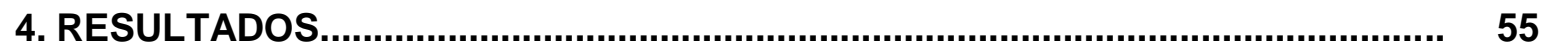

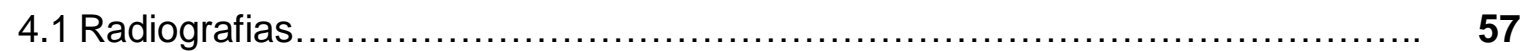

4.1.1 Grupos Controles.............................................................................. 57

4.1.2 Grupos Experimentais........................................................ 58

4.2 Avaliações Clínicas.......................................................................... 59

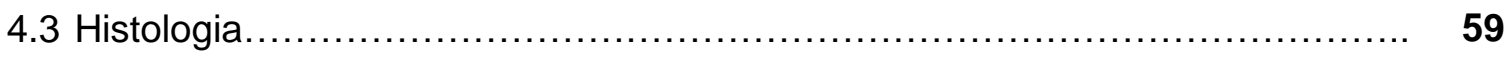

4.3.1 Grupos sem ERM 7 e 21 dias [Controle (GC) e com fumaça de cigarro (FC).

4.3.2Grupos Experimentais (ERM e ERM+FC) ....................................... 69

4.3.2.1 Grupo Expansão Rápida da Maxila (ERM).............................. 69

4.3.2.2 Grupo Expansão Rápida da Maxila e Fumaça de cigarro $(\mathrm{ERM}+\mathrm{FC})$. 


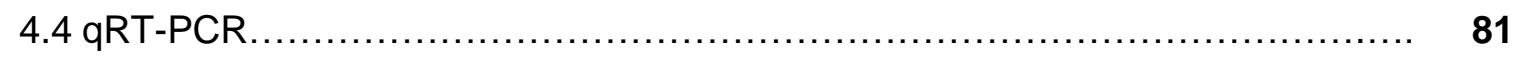

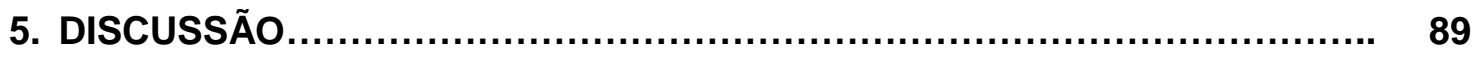

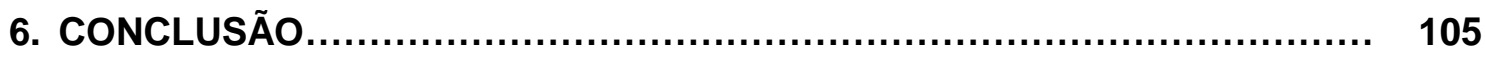

REFERÊNCIAS.............................................................................................. 109

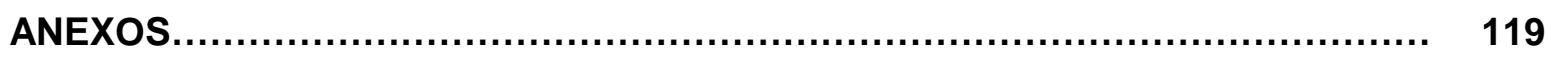


1. Introdução 



\section{INTRODUÇÃO}

A movimentação dentária é a base do tratamento ortodôntico. De acordo com Moyers (1991), o aparelho ortodôntico é um sistema que armazena e libera forças sobre dentes, músculos ou ossos, criando uma reação dentro do ligamento periodontal e no osso alveolar, provocando movimento dentário, alterando a morfologia óssea ou seu crescimento. A forma como o tecido ósseo responde à aplicação de forças nestes casos específicos ainda é pouco compreendida em termos biomoleculares (Krishnan e Davidovitch, 2006).

O movimento dentário é baseado no princípio biológico de que uma pressão prolongada aplicada aos dentes resulta em remodelação das estruturas periodontais como osso alveolar e ligamento periodontal (Kirkanydes et al., 2000). A transmissão da força gera uma resposta biológica descrita por Garlet e colaboradores (2007) como uma inflamação aguda e não patológica. Segundo Hughes (2000), este evento inflamatório desencadeia mudanças vasculares, síntese e liberação de prostaglandinas, citocinas e fatores de crescimento, os quais induzem à diferenciação de células mesenquimais indiferenciadas em osteoblastos e osteoclastos, responsáveis, respectivamente pela deposição e reabsorção do osso alveolar. A reabsorção da matriz óssea e a remodelação do colágeno extracelular ocorrem nas áreas de compressão e a deposição de osso alveolar e de colágeno, nas áreas de tração do ligamento periodontal (Nakagawa et al., 1994; Krishnan e Davidovitch, 2006; Masella e Meister, 2006).

O hábito de fumar cigarros deve ser considerado com certa importância pelo profissional ortodontista e odontopediatra uma vez que os fumantes têm uma saúde periodontal e regeneração tecidual muito pior do que os não fumantes, o que determina cuidados terapêuticos multidisciplinares (Collett et al., 1999). O tabagismo é considerado uma doença pediátrica pela Organização Mundial da Saúde (OMS) tendo em vista que $90 \%$ dos fumantes começam a fumar até os 19 anos. Estima-se que entre 82 mil a 99 mil jovens começam a fumar a cada dia no mundo. A experimentação de cigarros vem aumentando entre escolares brasileiros, com maiores índices entre as meninas adolescentes. Dos experimentadores, 50\% tornarse-ão fumantes regulares na vida adulta.

Os efeitos nocivos desse hábito não se limitam apenas ao organismo do indivíduo fumante. O tabagismo passivo caracteriza-se pelo ato de inalar a fumaça 
de derivados do tabaco (cigarro, charuto, cigarrilhas, cachimbo e outros produtores de fumaça) proveniente de um fumante, fazendo com que os malefícios do fumo ocorram mesmo em não-fumantes. O ar poluído contém, em média, três vezes mais nicotina, três vezes mais monóxido de carbono, e até cinqüenta vezes mais substâncias cancerígenas do que a fumaça que entra pela boca do fumante depois de passar pelo filtro do cigarro (Ministério da Saúde, 2002). Em estudo recente, apoiado pela OMS, estima-se que morrem todos os anos no mundo mais de 600000 não fumadores devido à exposição passiva ao fumo e que $28 \%$ destas mortes são crianças (Öberg et al., 2011).

De acordo com dados da OMS, aproximadamente dois bilhões de pessoas são vítimas do fumo passivo no mundo, sendo que destas, 700 milhões são crianças, que sofrem com maior incidência de bronquites, pneumonia e infecções de ouvido, entre outras doenças. No Brasil, as crianças são $40 \%$ das vítimas do fumo passivo. Crianças expostas à fumaça do cigarro têm maior risco de apresentarem doenças infecciosas do trato respiratório (bronquite, pneumonia e asma), otite média, doenças cardiovasculares, distúrbios de comportamento e do desenvolvimento neurológico e câncer, principalmente do pulmão. Todos estes efeitos são muito semelhantes aos descritos em adultos, mas as crianças são mais suscetíveis à toxicidade da fumaça do cigarro por serem imaturos em sua constituição.

Em bebês, observa-se um risco 5 vezes maior de morte súbita sem uma causa aparente (Síndrome da Morte Súbita Infantil) e maior risco de manifestarem doenças pulmonares até 1 ano de idade, proporcionalmente ao número de fumantes em casa. Filhos de fumantes parecem ter dificuldade de aprendizado, atraso no desenvolvimento da linguagem e mais problemas de comportamento, como hiperatividade, distúrbios de conduta e desatenção. Por fim, crianças que são fumantes passivas têm mais chances de tornarem-se fumantes no futuro (Butz et al., 2011).

A literatura apresenta uma série de eventos biológicos que alteram o nível local de mediadores químicos relacionados à remodelação óssea em resposta a um estímulo, representado pelas forças aplicadas via aparelho ortodôntico nos lados de pressão e tração. (Krishnan e Davidovitch, 2006), mas não esclarece o papel do hábito de fumar frente a estes mediadores. A nicotina, um importante componente do cigarro, acelerou o movimento dental ortodôntico em primeiros molares e 
incisivos superiores de ratos, em virtude da produção de prostaglandinas e o aumento da função de reabsorção dos osteoclastos (Sodagar et al., 2011). No entanto, alguns dos efeitos da nicotina podem prejudicar o processo de reparo, como a liberação de catecolaminas que diminuem a perfusão tecidual e a alteração no metabolismo dos fibroblastos (Tipton e Dabbous, 1995), além da diminuição da proliferação de hemácias, macrófagos e fibroblastos (Sherwin e Gastwirth, 1990). Outro componente da fumaça de cigarro que pode influenciar negativamente a reparação tecidual é o cianeto de hidrogênio, substância altamente tóxica utilizada em diversas áreas como inseticida e gás letal em execuções. O cianeto tem uma afinidade muito alta pelo ferro no estado férrico. Quando absorvido, reage prontamente com o ferro trivalente da citocromo oxidase na mitocôndria. A respiração celular é inibida resultando em acidose lática e hipóxia citotóxica (Klaassen, 1996). Essas alterações enzimáticas na respiração celular podem prejudicar o processo de reparo dos tecidos (Mosely e Finseth, 1977).

A nicotina, o monóxido de carbono e o cianeto são os elementos da fumaça de cigarro mais comumente relacionados a um processo de reparo tecidual prejudicado (Silverstein, 1992; Haverstoch e Mandracchia, 1998). Outros componentes de cigarro, como a acroleína e o acetaldeído têm mostrado in vitro um efeito prejudicial na proliferação e adesão de células importantes para o processo de cicatrização, como os fibroblastos (Cattaneo et al., 2000). Autores como Silverstein (1992) relatam ainda que outros constituintes da fumaça de cigarro também podem ter efeitos negativos sobre a reparação tecidual.

O tabaco provoca sobre as células endoteliais um aumento no nível do fator pré-coagulante Von Willenbrand. Estes danos endoteliais prejudicam o reparo após a movimentação ortodôntica em fumantes. Seguindo o comprometimento endotelial, existe o prejuízo à adesão e migração de células competentes para os sítios a serem reparados. A secreção dos fatores de crescimento celular pelas células endoteliais pode ser prejudicada, resultando em menor estímulo e ativação de linhagens imaturas de células (Grossi et al, 1996).

Alguns trabalhos in vitro têm demonstrado que a fumaça de cigarro e seus componentes apresentam efeitos negativos em culturas de células ósseas. Ramp e colaboradores (1988) estudaram o efeito da nicotina sobre as culturas de células do tipo osteoblasto. Os resultados mostraram que a nicotina inibiu a atividade da fosfatase alcalina e a síntese de colágeno num padrão dose-dependente. Em 2001, 
Liu e colaboradores realizaram um experimento avaliando a ação direta da fumaça de cigarro sobre as células osteoprogenitoras humanas. Observaram que a fumaça de cigarro inibiu a proliferação das células osteoprogenitoras em células tipo osteoblasto.

A análise da chamada qualidade óssea, sob o ponto de vista molecular, tem grande potencial para contribuir para um melhor entendimento dessa característica de formação óssea em fumantes submetidos à disjunção da maxila. A identificação molecular de reguladores da reabsorção e formação óssea pode contribuir para a investigação da fisiopatologia óssea nas áreas submetidas à disjunção e pode, em associação aos exames de imagem, caracterizar melhor a qualidade óssea.

Neste contexto, uma das principais vias de diferenciação e ativação dos osteoclastos envolve o sistema RANK (receptor ativador do fator nuclear kappa B) RANKL (RANK ligante) - OPG (osteoprotegerina). O RANKL é uma molécula importante para a diferenciação das células hematopoiéticas progenitoras em osteoclastos maduros e exerce seus efeitos por meio de sua ligação ao receptor RANK. Por outro lado, a osteoclastogênese é bloqueada na presença da OPG (Boyle et al., 2003), uma vez que quando OPG está ligada ao RANKL, este não pode ligar-se ao RANK, impossibilitando dessa forma que as células osteoprogenitoras se diferenciem em osteoclastos e não haja reabsorção óssea. $O$ desequilíbrio desse sistema RANK/RANKL/OPG é observado na osteoporose, artrite reumatoide, doença periodontal (Boyle et al., 2003; Amorim et al., 2008) e recentemente foi demonstrado em lesões fibro-ósseas da maxila e mandíbula (Elias et al., 2010).

Além da tríade RANK/RANKL/OPG, sabe-se que a carga mecânica induz a proliferação e a diferenciação das células ósseas e a síntese da matriz extracelular através de várias macromoléculas, dentre elas a osteopontina (OPN), osteocalcina (OCC), sialoproteína óssea (BSP) e proteína óssea morfogenética 2 (BMP-2) (Nomura e Takano-Yamamoto, 2000; Ivanovsky et al., 2001; Ehrlich e Lanyon, 2002). Quando uma força mecânica é aplicada no osso, o estresse é detectado por determinadas células, induzindo a remodelação óssea. Essas células mecanoresponsáveis são em sua maioria osteoblastos e osteoclastos (Ehrlich e Lanyon, 2002).

A OPN é uma das abundantes matrizes proteicas que são produzidas durante a aplicação de carga oclusal (Rodan, 1995; Denhardt e Noda, 1998; Nomura e Takano-Yamamoto, 2000; Sodek et al., 2000) e pode converter estresse mecânico 
através de um sinal intracelular (Carvalho et al., 1998). No tecido mineralizado, a osteopontina é expressa através dos fibroblastos (Ivanovski et al., 2001), células osteoblásticas (Merry et al., 1993) e osteoclastos (Merry et al., 1993; Dodds et al., 1995). O relacionamento entre a carga mecânica e a expressão da osteopontina tem sido estudado in vitro (Klein-Nulend et al., 1997; Carvalho et al., 1998) e in vivo (Takano-Yamamoto et al., 1994; Miles et al., 1998; Terai et al., 1999; Morinobu et al., 2003, Kaku et al., 2005).

Outra proteína importante relacionada ao metabolismo ósseo é a OCC. Esta é uma proteína secretada pelos osteoblastos maduros, condrócitos hipertrofiados e odontoblastos, e uma de suas funções está relacionada à ligação do cálcio à matriz óssea, por isso pode ser utilizada como um marcador bioquímico de formação óssea. O papel exato desta proteína na remodelação óssea não foi completamente elucidado, no entanto, mostrou-se como uma via importante da ativação da formação óssea através do seu efeito sobre os osteoblastos (Han et al., 2008).

Descobertas recentes na área de remodelação óssea, mais especificamente no campo dos biomarcadores de turnover ósseo, tem tornado as pesquisas sobre tratamento ortodôntico e aplicação de forças ortopédicas mais direcionadas e focadas principalmente na análise das proteínas envolvidas durante estes processos. Uma vez que os marcadores de turnover ósseo são derivados do osso cortical e trabecular, eles refletem a atividade metabólica do tecido ósseo (Cox et al., 2010), além de fornecer uma visão dinâmica do processo de formação e reabsorção óssea, funcionando como indicadores da função dos osteoblastos e dos osteoclastos, assim como da formação e da reabsorção óssea (Camozzi et al., 2007). Desta maneira, um melhor entendimento das mudanças dos marcadores do turnover ósseo durante a aplicação de forças ortopédicas no tecido ósseo, sob a influência da exposição à fumaça de cigarro, é de grande interesse, uma vez que esta análise é inédita e pode fornecer dados importantes relacionados à formação ou reabsorção óssea em situações adversas induzidas pelas toxinas do cigarro. Portanto, é importante avaliar neste contexto e em uma mesma pesquisa o comportamento da tríade RANK/RANK-L/OPG, fatores envolvidos na sinalização osteoblasto-osteoclasto, assim como avaliar a expressão gênica relacionada às proteínas não-colágenas como ONC, OCC, BSP, OPN e BMP-2, proteínas indicadoras de atividade celular, que são secretadas pelos osteoblastos e que estão envolvidas no processo de formação óssea. O objetivo deste estudo foi compreender 
a biodinâmica da remodelação óssea após movimentação ortodôntica em ratos submetidos à inalação de fumaça de cigarro, por meio da expressão gênica dos mediadores ósseos acima mencionados. 
2. Proposição 



\section{PROPOSIÇÃO}

\subsection{Objetivo Geral}

O objetivo do presente estudo foi investigar o efeito da inalação de fumaça de cigarro sobre os mediadores que modulam o processo de remodelação óssea em ratos submetidos ou não a forças ortopédicas para expansão rápida da maxila.

\subsection{Objetivos Específicos}

- Verificar se há diferença quantitativa na expressão gênica de Tnfrsf11a (Rank), Tnfsf11 (Rankl), Tnfrsf11b (Opg), Bglap (Occ), Sparc (Onc), Bmp2 (Bmp-2), Ibsp (Bsp) e Spp1 (Opn) em diferentes períodos de avaliação do reparo ósseo.

- Avaliar qualitativamente, por meio de descrições histológicas, a remodelação óssea na sutura palatina mediana nos diferentes tempos e grupos de análise. 

3. Material e Métodos 



\section{MATERIAL E MÉTODOS}

\subsection{Amostragem (Seleção dos Animais)}

Foram utilizados para este experimento 120 ratos da linhagem Wistar (Rattus norvegicus, albinus) machos com 6 semanas de vida (jovens em desenvolvimento) pesando em média $180 \mathrm{~g}$. Os animais foram fornecidos pelo Biotério Central da Universidade de São Paulo - campus Ribeirão Preto e este trabalho teve a aprovação da Comissão de Ética no Uso de Animal (CEUA - USP) sob o número de protocolo 2014.1.492.58.8 (ANEXO A, página 121). Durante todo o período experimental os animais foram alimentados com dieta padrão, constituída por ração moída (Labina - Purina) a fim de se evitar eventuais danos ao aparelho ortodôntico durante a mastigação; e água ad libitum. Animais machos foram utilizados para eliminar qualquer variabilidade hormonal devido ao ciclo reprodutivo feminino.

Durante o período experimental os animais permaneceram em gaiolas plásticas específicas para esse fim, com locais apropriados para a colocação de água e alimento, forradas com raspas de madeira (maravalha de pinus), ou seja, material totalmente inofensivo, atóxico, livre de peças pontiagudas, absorvente, isolante térmico, sem pó e não comestível pelos animais. Cada gaiola teve um número máximo de cinco animais. O foto período foi controlado com intervalos de dia-noite de 12 horas, para evitar alterações no ciclo metabólico e a temperatura da sala do biotério permaneceu estável entre $21^{\circ} \mathrm{C}$ e $23^{\circ} \mathrm{C}$, ideal para o crescimento e desenvolvimento dos animais. O local foi mantido constantemente arejado e limpo.

\subsection{Delineamento Experimental}

Para o período experimental de 3 e 14 dias foram utilizados cinco animais $(n=5)$, enquanto que para o período de 7 e 21 dias utilizaram-se 10 animais $(n=10)$ distribuídos aleatoriamente de acordo com a Tabela 1. Parte dos animais foi destinada à análise da expressão gênica ( $n=5 ; 3,7,14$ e 21 dias) e outra parte destinada à avaliação histológica ( $n=5 ; 7$ e 21 dias). 
Tabela 1- Grupos experimentais, tempos, número de animais e procedimentos propostos.

\begin{tabular}{ccccccc}
\hline GRUPOS & \multicolumn{5}{c}{ DESCRIÇÃO DOS GRUPOS EXPERIMENTAIS } \\
\cline { 2 - 6 } & $\mathbf{3}^{\circ}$ & $\mathbf{7}^{\circ}$ & $\mathbf{1 4}^{\circ}$ & $\mathbf{2 1}^{\circ}$ & Descrição \\
Grupo Controle Negativo & 5 & 10 & 5 & 10 & $\begin{array}{c}\text { Grupos sem expansão rápida da maxila e } \\
\text { sem fumaça de cigarro (GC) }\end{array}$ \\
Grupo Experimental I & 5 & 10 & 5 & 10 & $\begin{array}{c}\text { Animais sem expansão rápida da maxila e } \\
\text { com fumaça de cigarro (FC) }\end{array}$ \\
Grupo Experimental III & 5 & 10 & 5 & 10 & $\begin{array}{c}\text { Animais com expansão rápida da maxila e } \\
\text { com fumaça de cigarro (ERM + FC) }\end{array}$ \\
\hline
\end{tabular}

\subsection{Anestesia dos Animais}

Todos os procedimentos foram realizados sob sedação com $40 \mathrm{mg} / \mathrm{kg}$ de Ketamina (Agener®; Agener Uniao, Sao Paulo, SP, Brazil) e $20 \mathrm{mg} / \mathrm{kg}$ de Xylazina (Syntec®; Syntec, Santana do Parnaiba, SP, Brazil) numa proporção 1:2 respectivamente $(1 \mathrm{~mL} / \mathrm{Kg})$ por via intramuscular.

\subsection{Instalação e Ativação do Dispositivo Ortodôntico para a Disjunção da Sutura Palatina Mediana}

O mecanismo de força utilizado foi constituído de uma mola passiva de 1,5 $\mathrm{mm}$ de largura, confeccionada com fio de aço inoxidável de $0,5 \mathrm{~mm}$ de diâmetro (Morelli $^{\circledR}$, Sorocaba, Brasil), colocada entre os incisivos superiores (Figura 1, página 43), semelhante ao apresentado na literatura (Sawada and Shimizu, 1996; Saito and Shimizu, 1997; Silva et al., 2012; Arnez et al., 2017) com o intuito de possibilitar a correta calibração e padronização da força empregada em todos os animais e permitir manter a disjunção da sutura palatina mediana.

Todos os dispositivos ortodônticos foram confeccionados e instalados pelo mesmo operador e assistente, seguindo sempre o mesmo protocolo. A superfície dos incisivos foi previamente preparada à montagem do dispositivo para a disjunção maxilar, com objetivo de aumentar a retenção e estabilizar a mola inserida entre os incisivos superiores. Em seguida foi realizada profilaxia dos incisivos com pasta de pedra-pomes misturada com água aplicada em taça de borracha (Viking ${ }^{\circledR}$ ) em contra-ângulo adaptado ao micromotor (Dabi-Atlante ${ }^{\circledR}$ ) por 15 segundos. Foi realizada a lavagem com spray (água-ar) e a secagem com ar proveniente da 
seringa tríplice, seguido de condicionamento do esmalte nos incisivos utilizando ácido ortofosfórico a $37 \%$ em forma de gel $\left(3 \mathrm{M}^{\circledR}\right)$, durante 60 segundos, conforme recomendações do fabricante. Na sequência, nova lavagem e secagem das superfícies dentárias por 15 segundos. O agente de união (Primer e Bond 2.0 Dentsply $^{\circledR}$ ) foi aplicado sobre a superfície condicionada do esmalte e fotopolimerizado com luz halógena por 20 segundos com auxílio do aparelho Heliomat II $\left(\right.$ Vigodent $\left.^{\circledR}\right)$. A resina fotopolimerizável (Transbond-ETM ${ }^{\circledR}$ ) foi adaptada sobre o segmento de fio nas faces vestibular e distal recobrindo-o e, em seguida, foi induzida a polimerização por meio de luz halógena, com comprimento de onda de $470 \mathrm{~nm}$ (Heliomat II, Vigodent ${ }^{\circledR}$ ) durante 30 segundos, dirigida em orientação oclusal, vestibular, mesial e distal de cada incisivo. Para compensar o desgaste decorrente do contínuo hábito roedor dos animais, várias camadas de resina foram fotopolimerizadas sobre o grampo. Após a ativação inicial, o aparelho não recebeu outra ativação adicional durante o experimento e seu correto posicionamento foi conferido diariamente, quanto à posição, à estabilidade e à necessidade de correções na eventualidade de estar causando injúrias à mucosa oral do animal.

Figura 1- Vista oclusal durante instalação de dispositivo ortodôntico entre os incisivos centrais.
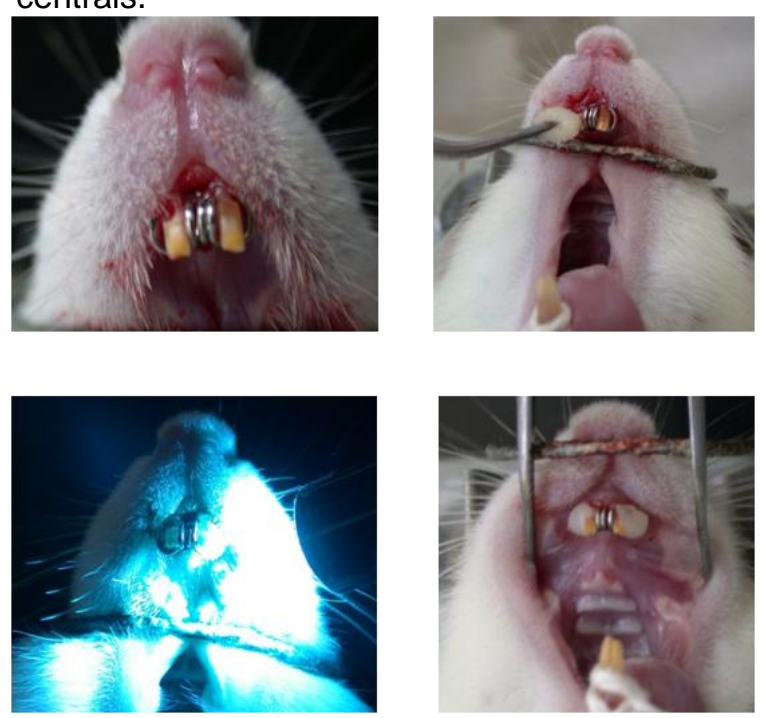


\subsection{Radiografias}

O exame radiográfico foi realizado no momento da eutanásia, a fim de confirmar a situação da sutura palatina mediana nos animais (intacta nos grupos que não foram submetidos à ERM) e confirmar a abertura da sutura após a disjunção. Estas radiografias foram realizadas neste período pois deste modo era possível a obtenção de radiografias comparáveis sem sobreposições ósseas.

Os animais foram radiografados utilizando filmes oclusais (Insight, Kodak, NY, EUA) que foram posicionados paralelos à sutura palatina mediana envolvendo toda a maxila. Utilizou-se o aparelho de Raio X (Kavo, Funk RX 10, RJ, Brasil) calibrado com tempo de exposição de 0,5 segundos, $10 \mathrm{~mA}$ e $60 \mathrm{KV}$ para obtenção de radiografias semelhantes. Os filmes radiográficos foram revelados em soluções de revelador (Kodak GBX, NY, EUA) e fixador (Kodak GBX, NY, EUA) de acordo com a técnica temperatura/tempo com lavagem intermediária em água durante 30 segundos e fixação por 15 minutos. Posteriormente, as radiografias foram colocadas em água corrente por 20 minutos e a secagem foi obtida naturalmente.

\subsection{Exposição à fumaça de cigarro}

A metodologia utilizada para a exposição dos animais à fumaça foi descrita inicialmente por Le Mesurier e colaboradores (1981) e readaptada por Nociti e colaboradores (2002). Trata-se de um recipiente de acrílico transparente, confeccionado especialmente para este fim (Bonter, Ensino e Pesquisa -

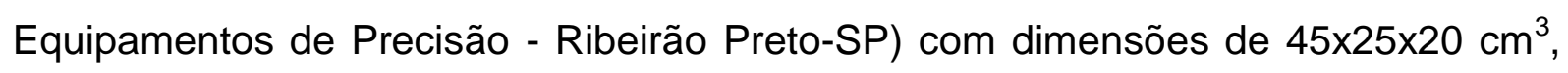
composto por 2 câmaras interligadas por um orifício. $\mathrm{Na}$ primeira ficaram armazenados os cigarros acesos. Nessa parte há também uma entrada por onde é bombeado ar, com um inalador (Inalar Compact NS) formando uma corrente que leva a fumaça para a segunda câmara, onde ficavam os animais. Na segunda câmara há outro orifício que proporciona vazão ao ar bombeado (Figuras 2 e 3 , página 45). 
Figura 2- Desenho esquemático representando o mecanismo de exposição à fumaça. Observa-se a câmara 1 onde os cigarros foram posicionados e a câmara 2, onde os animais permaneceram durante a exposição à fumaça de cigarro.

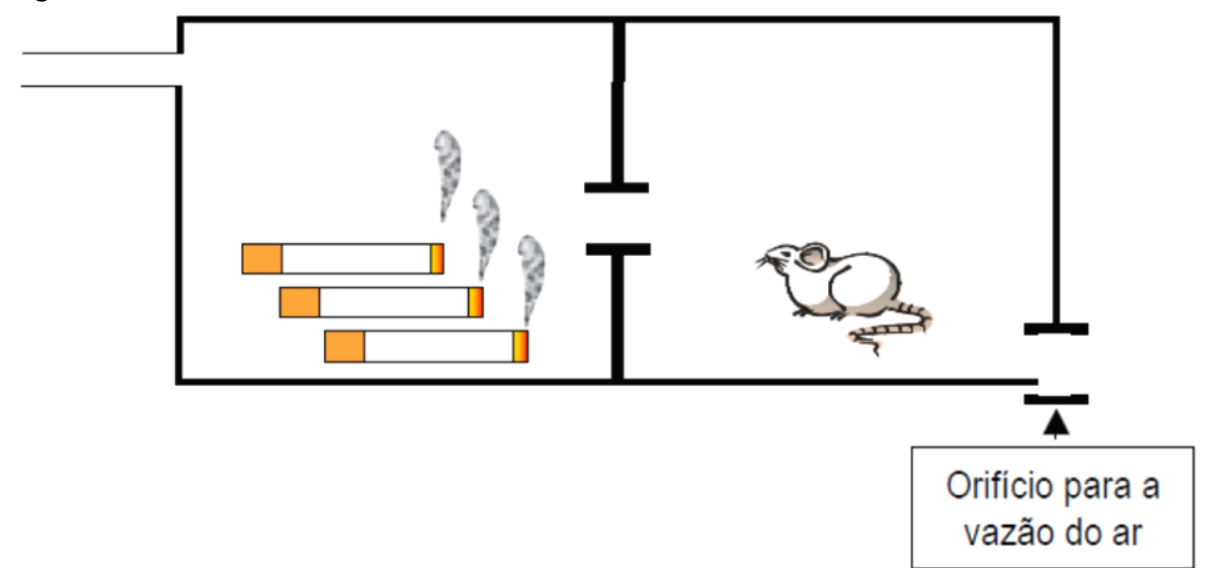

Figura 3- Câmara de exposição à fumaça de cigarro.

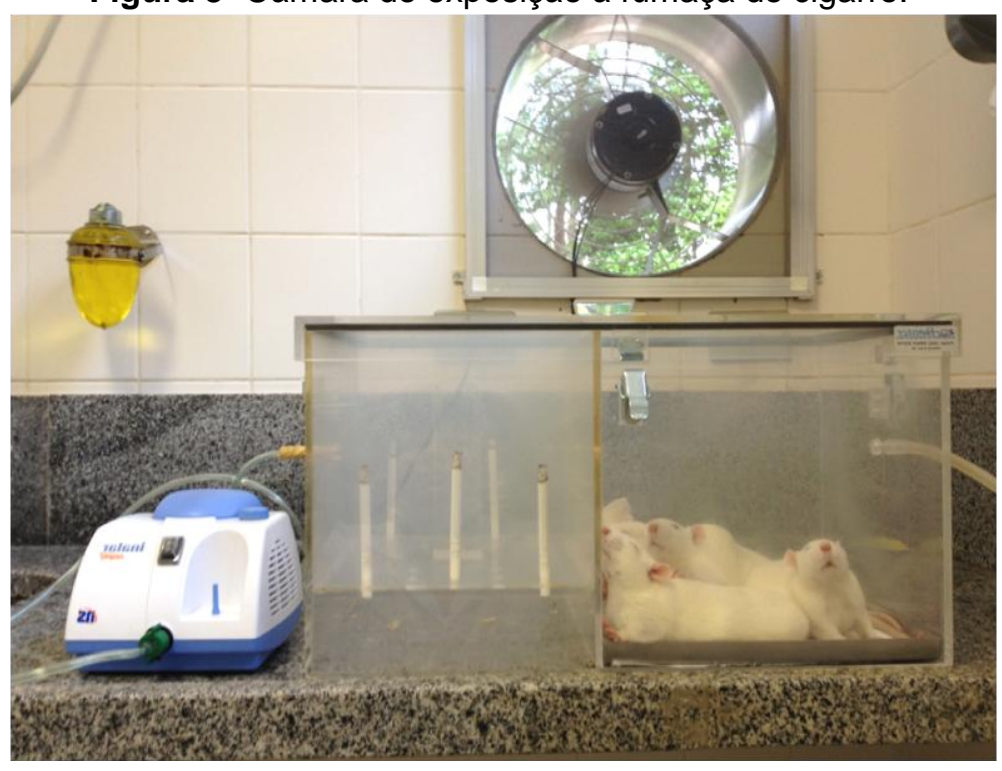

Os animais expostos à fumaça de cigarro foram submetidos a um período de adaptação prévio de 3 semanas antes da montagem do aparelho para ERM, conforme descrito em literatura (Pinto et al., 2002; Santiago et al., 2017).

Após a primeira e única ativação do mecanismo de força para ERM, os animais foram expostos à fumaça de 5 cigarros por dois períodos diários de 3 minutos cada, com intervalo de 12 horas entre as exposições. Após o período de 3 , 7, 14 e 21 dias preconizado para cada grupo experimental, os animais foram submetidos à eutanásia, conforme cronograma estabelecido no delineamento experimental (Tabela 1, página 42). 


\subsection{Eutanásia dos animais, coleta e preparo dos espécimes}

Os procedimentos operatórios foram realizados na sala de cirurgia experimental do Biotério I da FORP-USP, sob condições de limpeza, anti-sepsia e desinfecção, com instrumentos esterilizados em autoclave. Ao término dos períodos experimentais, os animais foram submetidos à eutanásia por uma injeção com sobredose de anestésico com Ketamina e Xilazina via intramuscular e, em seguida, foram decapitados. Espécimes contendo apenas o tecido da sutura palatina mediana dos diferentes grupos foram armazenados em tubos plásticos livres de RNAses (Eppendorf, São Paulo, Brasil), identificados e conservados em freezer a $-80^{\circ} \mathrm{C}$ para análise da expressão gênica. Espécimes contendo a maxila, incluindo a sutura palatina mediana, foram destinados à avaliação histológica e foram conservados em formol a $10 \%$ por 48 horas e posteriormente foi iniciado o processamento histológico.

\subsection{Análise da expressão gênica}

Os protocolos utilizados foram seguidos de acordo com Sambrook e Russel (2006) de uso comum na expressão gênica - Reação Quantitativa de Polimerase em Cadeia em Tempo Real (qRT-PCR). Inicialmente os espécimes foram pesados para dar sequência às diversas etapas para posterior avaliação da expressão gênica.

\subsubsection{Isolamento e avaliação do RNA total (Extração de RNA)}

O RNA total foi extraído da maxila dos animais $(50-100 \mathrm{mg})$ a partir da lise da suspensão de células mononucleares. Para isto as amostras de tecido ósseo foram inicialmente pulverizadas (maceradas) em grau com pistilo contendo nitrogênio líquido. A seguir os tecidos foram imersos em reagente Trizol (Invitrogen-Life Technologies, Carlsbad/CA, EUA), seguindo o protocolo recomendado pelo fabricante, na proporção de $1 \mathrm{~mL}$ de Trizol para cada $1 \mathrm{mg}$ de tecido, sendo agitado por 30 segundos e mantidos à temperatura ambiente por 5 minutos. As amostras foram homogeneizadas em agitador de tubos, seguidas da adição de $0,2 \mathrm{~mL}$ de clorofórmio para cada $\mathrm{mL}$ de suspensão, e centrifugadas a $12.000 \times \mathrm{g}$ por 15 minutos, a $4^{\circ} \mathrm{C}$, com formação de duas fases. A fase aquosa foi transferida para um novo tubo, ao qual foi adicionado o mesmo volume de isopropanol, sofrendo agitação em vortex e incubado por 20 minutos a $-20^{\circ} \mathrm{C}$ para precipitar o RNA da fase aquosa. Novamente os tubos foram centrifugados a $10.000 \times \mathrm{g}$, por 10 minutos, a $4^{\circ} \mathrm{C}$ e, o precipitado foi lavado em etanol a $75 \%(\mathrm{v} / \mathrm{v})$ e posteriormente seco à 
temperatura ambiente. As amostras de RNA foram suspensas em $50 \mu \mathrm{L}$ de água deionizada [estéril tratada com dietilpirocarbonato (DEPC) e livre de RNAse], incubadas por 10 minutos a $56^{\circ} \mathrm{C}$, e armazenadas no freezer a $-80^{\circ} \mathrm{C}$ para posterior análise. O RNA total isolado foi quantificado (A260nm) e foi avaliado o grau de pureza (A260/A280) através de espectrofotometria (Sambrook e Russel, 2006).

\subsubsection{Síntese do DNA complementar (cDNA)}

A síntese do cDNA foi obtida a partir do RNA total, por reação de transcrição reversa, com a utilização do kit High Capacity cDNA Reverse Transcription (Applied Biosystems $^{\circledR}$, Foster City, CA, EUA), de acordo com o protocolo descrito pelo fabricante. As amostras armazenadas em freezer a $-80^{\circ} \mathrm{C}$ foram descongeladas $\mathrm{e}$ mantidas em gelo. Novos tubos eppendorfs de $0,1 \mathrm{~mL}$ foram preparados com suas respectivas identificações para transcrição do cDNA. Utilizou-se $2 \mu \mathrm{g}$ de RNA total de cada amostra para a síntese do cDNA. Adicionou-se às amostras a quantidade recomendada pelo fabricante de cada componente do kit High Capacity cDNA Reverse Transcription (tampão RT, dNTP mix, primers, Multiscribe ${ }^{\mathrm{TM}}$ transcriptase reversa e água livre de nuclease) para obtenção de um volume final de $40 \mu \mathrm{L}$. A reação de transcrição reversa foi realizada em termociclador Veriti (Applied Biosystems $^{\circledR}$, Foster City, CA, EUA). As amostras foram colocadas em placas adaptadas para termociclador programado para atingir as condições de ciclagem recomendadas pelo fabricante. As amostras foram incubadas a 25ำ por 10 minutos para ligação do primer ao RNA, seguida de incubação a 37으 por 2 horas para transcrição reversa, utilizando a enzima transcriptase reversa, e posterior incubação a $85^{\circ} \mathrm{C}$ por 5 segundos para inativação da enzima e finalização do processo. Após a obtenção do cDNA, as amostras foram estocadas em freezer a $-20^{\circ} \mathrm{C}$ até a realização do qRT-PCR.

3.8.3 Reação em Cadeia da Polimerase (PCR) após Transcrição Reversa ou PCR em tempo real (qRT-PCR)

A reação da polimerase em cadeia tem por objetivo amplificar os cDNAs provenientes das diferentes amostras, obtendo amplicons (segmentos de cDNA gerado pelo processo de PCR) em escala exponencial.

Os cDNAs dos genes de interesse Tnfrsf11a (Rank), Tnfsf11 (Rankl), 
Tnfrsf11b (Opg), Bglap (Occ), Sparc (Onc), Bmp2 (Bmp-2), Ibsp (Bsp), Spp1 (Opn) e do gene constitutivo, gliceraldeído-3-fosfato desidrogenase (Gapdh), foram amplificados em aparelho para PCR em tempo real. As leituras de fluorescência foram realizadas pelo equipamento StepOne Plus (Applied Biosystems ${ }^{\circledR}$, Foster City, CA, EUA). O Gapdh foi utilizado como gene de referência, a água destilada deionizada como controle negativo e RNA de uma das amostras foi adicionada aos primers ao invés de cDNA, para confirmar ausência de DNA genômico para os experimentos da reação de qRT-PCR.

As amplificações por PCR foram realizadas em duplicata utilizando placas de 96 poços. Para as reações de qRT-PCR foram utilizadas alíquotas de $10 \mathrm{ng}$ de cDNA de cada amostra, que foram adicionadas à $10 \mu \mathrm{L}$ de Taqman ${ }^{\circledR}$ Gene Expression Master Mix (Applied Biosystems ${ }^{\circledR}$, Foster City, CA, EUA), $1 \mu \mathrm{L}$ de TaqMan ${ }^{\circledR}$ Gene Expression Assays (primers e sondas específicos para cada gene de interesse) (Applied Biosystems ${ }^{\circledR}$, Foster City, CA, EUA), acrescido de quantidade necessária de água livre de RNAse para obtenção de uma solução com volume final de $20 \mu \mathrm{L}$ por poço.

Os primers e sondas do sistema TaqMan ${ }^{\circledR}$ Gene Expression Assays foram obtidos cormercialmente e por serem propriedades privadas, as sequências não estão disponíveis. Os primers e sondas selecionados foram Tnfrsf11b (Opg Rn00563499_m1), Tnfrsf11a (Rank - Rn01426423_m1), Tnfsf11 (Rankl Rn00589289_m1), Bglap (Occ - Rn00566386_g1), Sparc (Onc - Rn01470624_m1), Bmp2 (Bmp2 - Rn00567818_m1), Ibsp (Bsp - Rn00561414_m1) e Spp1 (Opn Rn01449972_m1) e o gene de referência Gapdh (Gapdh-Rn00667869_m1).

Posteriormente, montou-se o layout das placas para as reações de qRTPCR serem lidas no aparelho StepOne Plus ${ }^{\circledR}$ (Applied Biosystems ${ }^{\circledR}$, Foster City, CA, EUA), que realiza as reações de amplificação e detecção. Colocou-se $20 \mu \mathrm{L}$ das diferentes amostras em cada poço da placa. As condições de amplificação das diferentes etapas da reação de qRT-PCR foram realizadas de acordo com as recomendações de tempo e temperatura propostas pelo fabricante (estágio $1: 95^{\circ} \mathrm{C}$ por 10 minutos para ativação da polimerase, estágio 2: 40 ciclos cada um com temperatura de $95^{\circ} \mathrm{C}$ por 15 segundos para desnaturação do DNA e $60^{\circ} \mathrm{C}$ por 1 minuto para anelamento do primer e polimerização). 
Os dados foram analisados no software StepOne ${ }^{\mathrm{TM}}$ versão 2.3. Todas as reações foram submetidas às mesmas condições de análise e normalizadas pelo sinal do corante de referência passiva ROX para correção de flutuações na leitura não relacionadas ao PCR, ou seja, flutuações decorrentes das variações de volume e evaporação ao longo da reação de PCR. Este programa quantifica as amostras por meio da análise da quantidade de fluorescência gerada pela liberação do fluoróforo 6FAM aos produtos de amplificação durante o curso da reação de PCR. Neste sistema, o fluoróforo 6-FAM foi utilizado como repórter na sonda Taqman. A liberação do fluoróforo acontece quando a enzima Taq DNA polimerase promove a extensão do primer e sintetiza a fita nascente de cDNA. Esta enzima apresenta atividade exonuclease 5', que degrada a sonda que está anelada à fita de cDNA. A degradação da sonda permite a liberação do fluoróforo (repórter), que emite o sinal fluorescente na cor azul (comprimento de onda de $495 \mathrm{~nm}$ a $521 \mathrm{~nm}$ ).

Os resultados foram analisados com base no valor do ciclo limiar $\mathrm{C}_{\mathrm{T}}$ (cycle threshold), que se refere ao número de ciclos de PCR necessários para que o sinal fluorescente atinja o limiar de detecção. Os resultados individuais expressos em valores de $\mathrm{C}_{\mathrm{T}}$ foram a seguir transferidos para planilhas e agrupados de acordo com os diferentes grupos de estudo e de período experimental, para a realização da análise estatística.

\subsection{Processamento histológico}

Após a eutanásia, amostras dos períodos de 7 e 21 dias foram fixadas em formol tamponado a $10 \%$ por 48 horas, em frascos individuais. Na sequência, os espécimes foram lavados em água corrente por 24 horas e colocados em solução desmineralizadora à base de EDTA a 10\% (etileno-diamino-tetra-acético), tamponado em $\mathrm{pH}$ neutro $(7,0$ - 7,4), por um período de 4 semanas. Durante a descalcificação, as peças foram armazenadas individualmente, em frascos esterilizados, contendo quantidade de solução descalcificadora equivalente a vinte vezes o volume da peça. Esta solução foi renovada a cada 72 horas, com o intuito de preservar a matriz orgânica durante o processo de descalcificação. A confirmação da descalcificação das secções anatômicas foi realizada através de radiografias obtidas das peças anatômicas, durante o período de descalcificação, a fim de avaliar o grau de calcificação das peças.

Depois de submetidos à desmineralização, todos os espécimes foram 
imersos em sulfato de sódio a 5\% por 24 horas à temperatura ambiente, com a finalidade de neutralizar a ação da solução descalcificadora. Os espécimes foram lavados em água corrente por $24 \mathrm{~h}$. Posteriormente, foi realizada desidratação em concentrações crescentes de álcoois, 70\%, 80\%, 90\% e 100\% (Reagen, PR, Brasil), sucessivamente, por 60 minutos à temperatura ambiente, a fim de evitar trocas osmóticas bruscas, o que poderia causar alterações nas estruturas teciduais. Concluída a desidratação, as peças foram diafanizadas em três banhos de xilol (Merck, RJ, Brasil). O xilol é miscível em álcool e em parafina, isto é, remove todo o álcool das peças anatômicas e fornece ao tecido condições de ser impregnado pela parafina. O tempo de imersão em cada solução de xilol I, II e III dependeu da evolução da diafanização. De modo geral, as peças ficaram em torno de uma hora em cada solução.

Após o xilol substituir todo o álcool nas peças, estas foram submetidas a parafinização lenta, promovida por seguidos banhos de xilol-parafina, nas proporções de $2: 1,2: 2$, e parafina pura (Reagen, PR, Brasil), sendo que as peças ficaram imersas uma hora em cada banho. Durante este procedimento as peças foram mantidas em estufa de temperatura constante regulada para $58^{\circ} \mathrm{C}$, até que o xilol fosse completamente substituído pela parafina fundida. Os blocos de parafina solidificados foram identificados e colocados em água gelada e, em seguida, no refrigerador, para evitar sua cristalização.

Cortes axiais e longitudinais semi-seriados foram obtidos em micrótomo com espessura de $5 \mu \mathrm{m}$. As fitas foram levadas ao cristalizador (Robertshaw, IL, EUA), onde foram distendidas e montadas em lâminas silanizadas para microscopia (Objektträger - Knittel Gläser, Bielefeld, Alemanha). Posteriormente, estas lâminas foram mantidas em estufa, em posição vertical, por 24 horas, a $40^{\circ} \mathrm{C}$, para a remoção da umidade e aderência do material à lâmina.

Para os cortes serem submetidos à coloração foi realizada a desparafinização das lâminas. Primeiro eliminou-se a parafina dos cortes utilizandose xilol puro (xilol I, II e III) com duração de 30 minutos por solução. Assim que foi constatada a eliminação da parafina dos cortes, iniciou-se o processo de hidratação. O xilol foi removido com banhos de álcool absoluto e, em seguida, foram utilizadas porcentagens decrescentes de soluções de álcoois a 90\%,70\% e 40\% e à água destilada. Os cortes permaneceram em cada solução por 3 minutos. A finalidade deste método foi de evitar fenômenos osmóticos bruscos que produziriam retrações e 
deslocamento do material da lâmina.

Parte dos cortes hidratados foram submetidos à coloração por hematoxilina (Merck, RJ, Brasil) por 10 minutos. Realizou-se a lavagem das lâminas em água corrente até os tecidos assumirem tom azulado. Em seguida foram mergulhadas rapidamente em solução de ácido clorídrico a 1\% diluído em álcool a 70\%. Nova lavagem foi realizada em água corrente por 5 a 10 minutos e foi realizada rapidamente uma passagem em álcool a 95\%. A eosina (Merck, RJ, Brasil) foi utilizada de 1 a 3 minutos, a fim de fornecer aos tecidos a cor rosada. A seguir, foi realizada nova desidratação com porcentagens crescentes de soluções de álcool (40, 60, 80 e 95\%) até chegar ao álcool absoluto. As lâminas foram submetidas a dois banhos de xilol. Posteriomente, as lâminas foram cobertas com lamínulas montadas com Entelan (Merck, RJ, Brasil).

Outra parte dos cortes hidratados foram submetidos à coloração por hematoxilina de Harris (solução de hematoxilina, alúmen de potássio, óxido vermelho de mercúrio, álcool 95\% e água destilada) por 5 minutos. Realizou-se a lavagem das lâminas em água corrente até os tecidos assumirem tom azulado. Em seguida foram mergulhadas em solução de Cromotrop 2R (solução de cromotrop, anilina, ácido fosfotungstico e água destilada) por 20 minutos. Nova lavagem foi realizada em água corrente por 5 a 10 minutos. A seguir, foi realizada nova desidratação com porcentagens crescentes de soluções de álcool (40, 60, 80 e 95\%) até chegar ao álcool absoluto. As lâminas foram submetidas a dois banhos de xilol. Posteriomente, as lâminas foram cobertas com lamínulas montadas com Entelan (Merck, RJ, Brasil). O protocolo descrito corresponde à coloração de Tricrômico de Masson rápido.

\subsection{Análise dos resultados}

\subsection{1 qRT-PCR}

\section{Eficiência de amplificação}

A análise da curva de amplificação dos fragmentos obtidos pela reação de PCR em tempo real permitiu avaliar a análise quantitativa da expressão relativa de cada um dos genes investigados.

O estudo da eficiência foi realizado para cada primer, utilizando 3 ou 4 diluições seriadas da amostra (template). Com o intuito de avaliar a eficiência de amplificação de cada gene-alvo, foram realizadas diluições seriadas de cDNA para 
que fossem submetidas à amplificação nas mesmas condições acima citadas. $O$ gráfico gerado pela concentração de cDNA e os respectivos valores de $\mathrm{C}_{T}$ foram empregados para o cálculo da equação de regressão e a correlação entre as variáveis pelo $\mathrm{R}$-quadrado.

\section{Método $\Delta \triangle C_{I}$}

Este método foi validado para o cálculo da expressão relativa de todos os genes avaliados por meios dos primers utilizados no presente estudo (Livak \& Schmittgen, 2001). No final dos ensaios de reação foi obtido o $\mathrm{C}_{\mathrm{T}}$ do aumento da fluorescência ocorrido durante os ciclos de reação. Os dados ópticos foram analisados com o auxílio do programa 7500 System Software. Para normalizar os valores de $\mathrm{C}_{\mathrm{T}}$, de forma a considerar diferenças causadas por quantidades distintas de cDNA utilizadas nas reações, o $\mathrm{C}_{\mathrm{T}}$ determinado para uma amostra foi subtraído do $\mathrm{C}_{\mathrm{T}}$ do gene de referência da mesma amostra, gerando assim o $\Delta \mathrm{C}_{\mathrm{T}}$. Para cada gene, o cálculo de expressão relativa foi realizado a partir da diferença entre $\Delta C_{T}$ das amostras e o $\Delta \mathrm{C}_{\mathrm{T}}$ apresentado pelo controle $\left(\Delta \Delta \mathrm{C}_{\mathrm{T}}\right)$, com base na expressão do gene de referência.

A seguir foi calculado o $\Delta \Delta \mathrm{Ct}$ considerando como calibrador o grupo controle (C), no período de 3 dias. $O$ cálculo $\Delta \Delta \mathrm{C}_{\mathrm{T}}$ baseado na reação exponencial da PCR foi obtido a partir da expressão $Q R=2^{-\Delta \Delta C T}$, no qual $Q R$ representa o nível de expressão gênica relativa, $C_{T}$ o ciclo de amplificação na qual cada amostra apresenta amplificação exponencial, $\Delta \mathrm{C}_{\mathrm{T}}$ se refere à diferença entre $\mathrm{C}_{\mathrm{T}}$ da amostra amplificada para o gene alvo e $\circ \mathrm{C}_{\mathrm{T}}$ da mesma amostra amplificada para o gene de referência e $\Delta \Delta \mathrm{C}_{\mathrm{T}}$ representa a diferença entre o $\Delta \mathrm{C}_{\mathrm{T}}$ da amostra interesse e o $\Delta \mathrm{C}_{\mathrm{T}}$ da amostra de referência-calibrador. A quantificação relativa foi utilizada para analisar alterações na expressão gênica em uma determinada amostra relativa à outra amostra de referência, isto é, uma amostra controle não tratada.

\subsubsection{Avaliação histológica}

A avaliação histológica foi realizada a fim de se descrever e observar os tipos celulares, o processo de remodelação óssea e o tecido ósseo neoformado na região da sutura palatina mediana. Estes dados posteriormente foram associados à expressão gênica, a fim de relacionar se o gene que foi estimulado ou inibido nas condições de fumaça de cigarro e ERM refletiam uma condição de formação ou 
reabsorção óssea no tecido.

Em microscopia de luz foram feitas as descrições histológicas da expansão maxilar da sutura palatina. Utilizou-se o microscópico Olympus BX61 acoplado à câmera DP72 (Tokio, Japão) e para a captura das imagens foi usado o programa DP2-BSW versão 2.2. Estas avaliações dos espécimes foram feitas em aumentos progressivos da área de interesse.

\subsection{Análise Estatística}

Os resultados do qRT-PCR para cada gene foram agrupados de acordo com os diferentes grupos de estudo e de período experimental, e submetidos à analise de variância Anova (one-way e two-way) seguido pelo pós-teste de Tukey e Bonferroni. A diferença foi considerada estatisticamente significante quando $p<0.05$. 



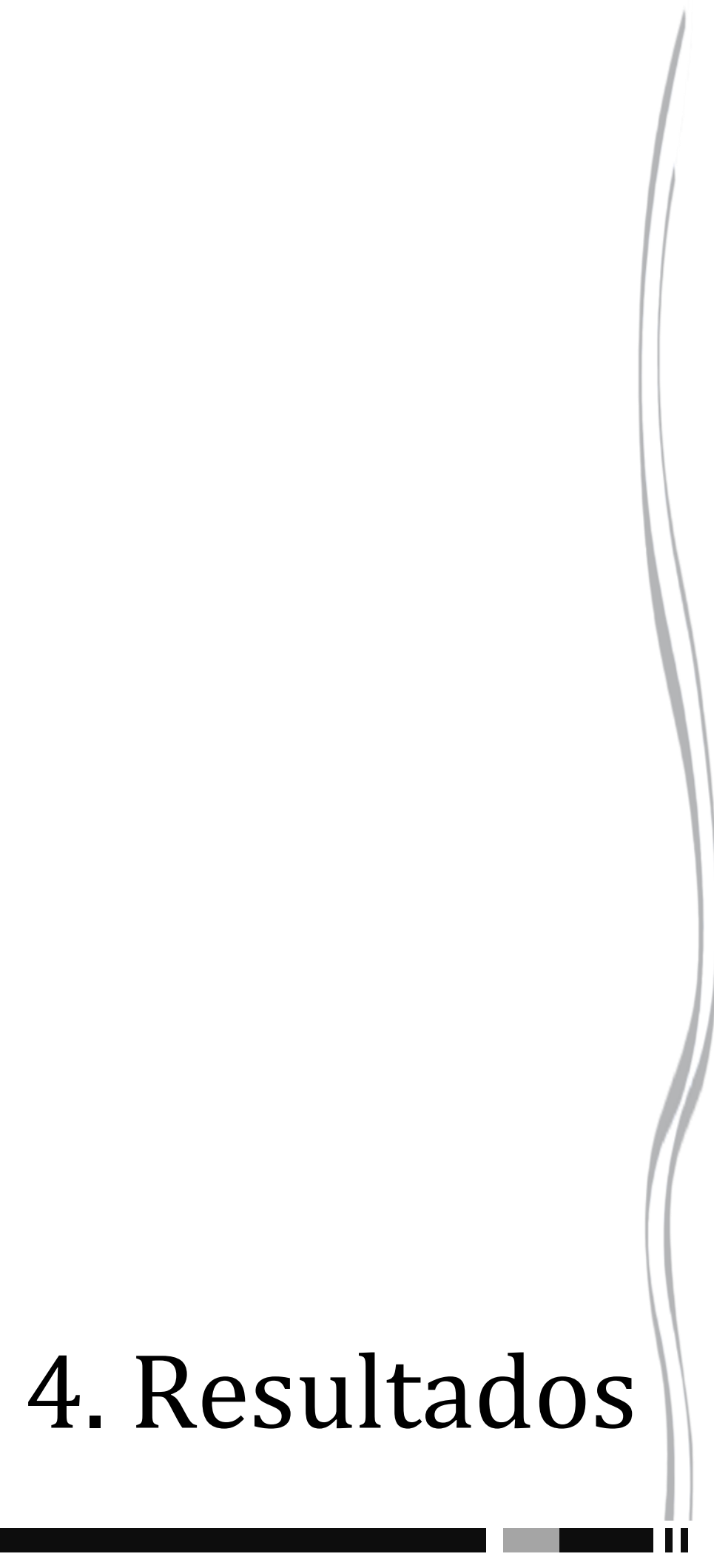





\section{RESULTADOS}

\subsection{Radiografias}

\subsubsection{Grupos Controles}

Todas as peças anatômicas foram radiografadas imediatamente após o sacrifício e para isso os filmes radiográficos oclusais foram posicionados paralelos à rafe palatina mediana, envolvendo toda a maxila.

A radiografia oclusal dos grupos sem ERM apresentou a imagem dos molares e incisivos centrais superiores, presença de pontos de contatos proximais entre os dentes, bem como a presença da sutura palatina mediana, representada por uma linha radiolúcida fina, delimitada por lâmina dura caracterizada por linhas radiopacas definidas, uniformes e eqüidistantes uma da outra. O osso trabecular apresentou aparência normal caracterizada pela imagem alternada de áreas radiolúcidas e finos tabiques radiopacos. As coroas dos incisivos superiores estavam em contato e mostravam paralelismo de raiz (Figura 4A, página 58).

\subsubsection{Grupos experimentais}

$\mathrm{Na}$ radiografia dos grupos submetidos à ERM foi visualizado um espaço radiolúcido, definido, nítido, correspondendo ao espaço sutural, porém mais amplo que no grupo controle. Foi observada a separação do ponto de contato entre os incisivos superiores, pois este espaço foi mantido pela largura mésio-distal do dispositivo ortodôntico em posição mesmo nos períodos mais prolongados do experimento (21 dias). Este espaçamento interincisal foi mantido até o final do período experimental, confirmando os achados clínicos e histológicos. As características da lâmina dura e do osso trabecular foram semelhantes aos animais que não foram submetidos à ERM (Figura 4B, página 58). 


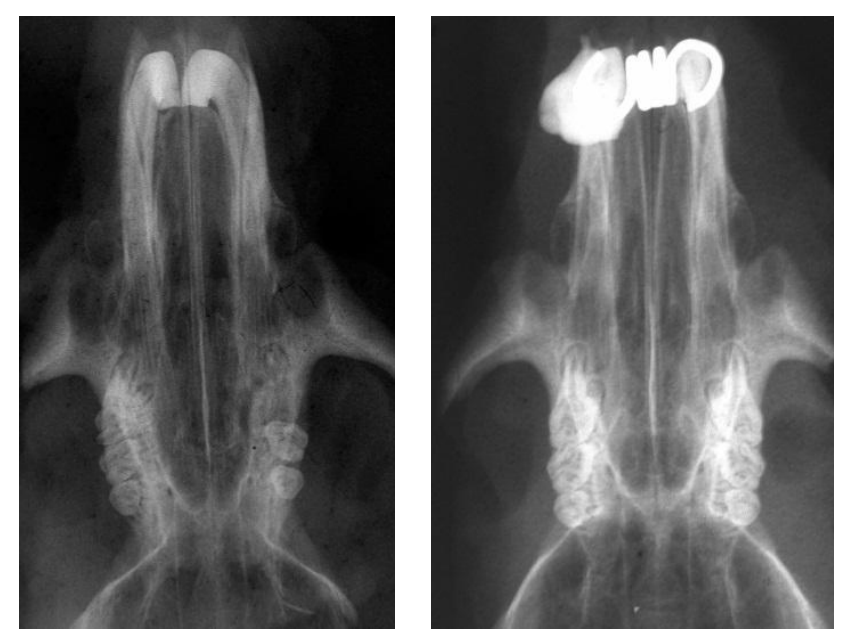

Figura 4- A: Radiografia da sutura palatina mediana intacta. B: Radiografia de confirmação da abertura da sutura palatina mediana após ERM.

\subsection{Avaliações clínicas}

Os animais desenvolveram-se normalmente e não apresentaram qualquer desvio clínico durante o experimento. Quanto à variação de peso apresentada pelos animais, o peso inicial foi, em média, 180 gramas. Os animais dos Grupos Experimentais que foram sacrificados aos 21 dias ganharam peso durante 0 transcorrer do experimento até o momento do sacrifício (média de peso final ao redor de 285g), evidenciando que os procedimentos não resultaram em desconforto contínuo para os animais. Isto confirma que a mudança na consistência da ração (moída) destinada aos animais dos Grupos Experimental não foi prejudicial.

Durante avaliação clínica, pode-se notar que em todos os animais sem ERM a gengiva marginal livre apresentava-se sadia, sem sinais clínicos de inflamação ou ulceração. Não se observou separação dos pontos de contato entre os incisivos centrais, apenas na região cervical, onde estava presente a papila interdental, achados clínicos que foram confirmados na avaliação histológica.

Nos animais submetidos à ERM, após a remoção do aparelho ortodôntico que estava fixado nos incisivos centrais superiores, observou-se a demarcação do grampo sobre a mucosa fina, sem áreas de ulceração, porém com a presença de leve hiperplasia gengival. Observou-se ainda a separação do ponto de contato entre os incisivos superiores. Estes resultados foram confirmados pelos exames histológicos e radiográficos. 


\subsection{Histologia}

Cortes histológicos semi-seriados longitudinais e frontais da sutura palatina mediana, de todos os animais da amostra, foram analisados. Em cada lâmina preparada, pode-se observar a sutura palatina mediana em toda a sua extensão, desde a região dos incisivos centrais até a região dos molares. O modelo de aparelho instalado promoveu a abertura da sutura (em formato em "V") somente até a porção média da maxila, ao nível das superfícies mesiais dos primeiros molares. Desta maneira, serão descritos os aspectos histológicos relacionados apenas a essa região específica, cujas fibras foram tracionadas durante o processo de disjunção. Com o auxílio do registro de cada fenômeno, de forma qualitativa, em quadros constando características tissulares (ANEXO B, página 122), procurou-se descrever os aspectos histológicos.

\subsubsection{Grupos sem ERM aos 7 e 21 dias [Controle (GC) e com fumaça de cigarro} (FC)]

Estes grupos compreenderam os animais com a sutura intacta, ou seja, não foram submetidos à ERM. Nestes grupos os períodos de 7 e 21 dias mostraram-se semelhantes, desta forma foram descritos em conjunto.

O exame histológico das estruturas (fibras, células, tecido conjuntivo, tecido ósseo e vasos sanguíneos) da região da sutura palatina mediana dos animais dos grupos controle (GC, FC) mostrou características histológicas compatíveis com a normalidade, isto é, aspectos de remodelação óssea fisiológica. Estas avaliações serviram como base para comparação com os animais dos grupos experimentais (ERM, ERM+FC). As características histológicas foram semelhantes em todos os grupos sem disjunção, ou seja, a fumaça de cigarro sozinha não demonstrou diferenças histológicas em relação ao grupo controle. Uma vez que tampouco houve diferença entre os diferentes períodos avaliados, a descrição histológica dos grupos controle (GC, FC) aos 7 e 21 dias de experimento foi realizada conjuntamente.

A superfície óssea sutural nos animais sem ERM apresentou-se regular, organizada, ligeiramente ondulada e lisa em todo o seu contorno, exceto quando da presença da irrigação proveniente dos espaços medulares subjacentes, que penetravam na região da sutura como perfurações na superfície óssea. Recobrindo ao longo dessa superfície óssea, verificou-se uma fina camada de tecido osteóide com presença de osteoblastos em repouso (células achatadas com núcleos paralelos à superfície óssea, pouco evidentes). A presença de osteoblastos ativos (células grandes e arredondadas com núcleos cubóides, volumosos e de coloração 
mais clara) enfileirados na superfície do tecido osteóide foi detectada. Estes osteoblastos geralmente se apresentavam de maneira organizada com intensa atividade de síntese. Porém a maioria dessas células estava inativa, recobrindo a superfície das bordas ósseas.

O espaço sutural apresentou uma espessura uniforme em toda sua extensão, ocupado pelo tecido conjuntivo sutural fibroso, rico em fibroblasto e em fibras colágenas e com presença de capilares em toda sua extensão. Os fibroblastos caracterizaram-se por possuírem núcleo ovóide, claro e com nucléolo evidente. $\mathrm{Na}$ região anterior da sutura, os feixes de fibras colágenas inseridos no osso (fibras de Sharpey) eram espessos, com orientações perpendiculares ou oblíquas à superfície da sutura. No terço médio da sutura, observaram-se feixes de fibras com orientações variadas e sagitais, que se misturavam com o tecido conjuntivo sutural. Na região posterior da sutura, essas fibras colágenas se estenderam de uma superfície à outra do osso, de tal forma que foi possível verificar a nítida conexão entre as bordas da sutura. Ainda nesta região, notaram-se numerosos fibrócitos, poucos fibroblastos e fibras colágenas delgadas sem orientação definida. Na região do centro da sutura, a maioria das fibras estava inserida perpendicularmente ao osso e projetavam-se para o centro do espaço sutural nas mais diversas direções, formando um emaranhado de fibras.

Os vasos sangüíneos, geralmente, seguiram a orientação dos feixes de fibras colágenas. O lúmem vascular era circular ou levemente ovalado e alguns vasos estavam repletos de células sanguíneas.

No osso da pré-maxila pode-se observar cavidades medulares e canais de Havers na sua porção lateral. Na sua porção medial, as trabéculas estavam paralelas à linha mediana e separadas por linhas de aposição óssea. A camada de tecido ósseo maduro (lamelar ou tecido ósseo secundário) era estreita quando comparada à camada de tecido ósseo imaturo (não lamelar ou primário), que estava circundando as bordas laterais da sutura palatina mediana. Além disso, notou-se a presença de numerosos osteócitos no interior de suas lacunas. Os sistemas de Havers caracterizaram-se por estarem organizados e circundados por pequenas cavidades medulares, preenchidas por tecido conjuntivo fibroso. Cada sistema de Havers caracterizou-se por inúmeras lamelas concêntricas, agrupadas ao redor do canal axial estreito, contendo vasos sangüíneos e pequena quantidade de tecido conjuntivo frouxo. A principal diferença observada no grupo FC foi a presença de uma maior faixa de tecido ósseo imaturo quando comparado ao grupo Controle (Figuras 5, 6, 7 e 8, páginas 61, 63, 65 e 67, respectivamente). 
Figura 5- Região da sutura palatina mediana do grupo controle 7 dias corte frontal (A) e longitudinal (B, C, D), onde observa-se: A) visão panorâmica da sutura palatina mediana mostrando tecido conjuntivo sutural (TC) delimitado por tecido ósseo (O). B), C) e D) detalhe da sutura onde é possível verificar osso (0) recoberto por osteoblastos delimitando a superfície óssea (setas pretas), fibras colágenas inseridas no tecido ósseo (FC) e vasos sanguíneos (V) por toda extensão do tecido sutural. Coloração H/E e Tricrômico de Masson.
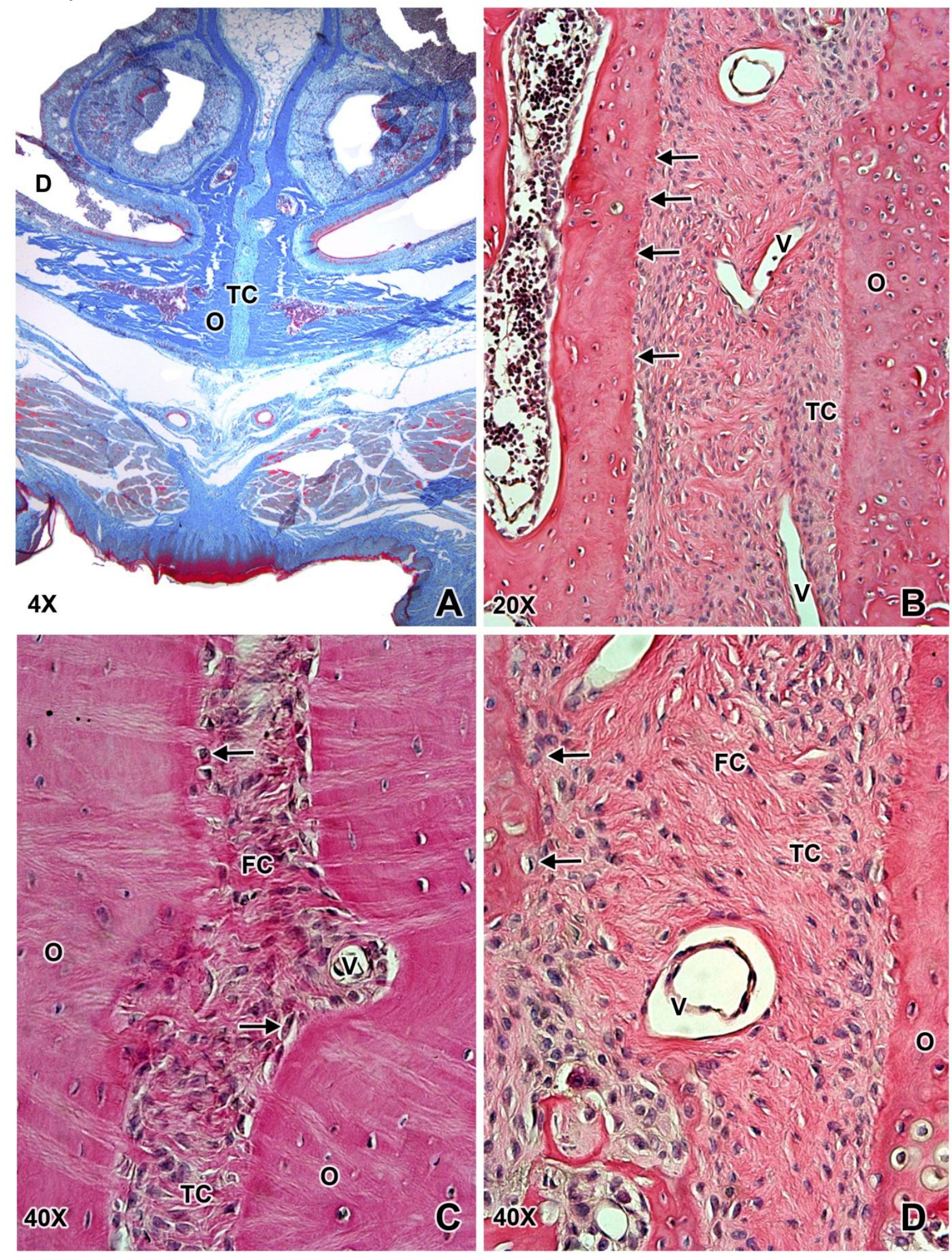

Figura 6- Região da sutura palatina mediana do grupo controle 21 dias cortes longitudinais (A, B, C, D), onde observa-se: A) visão panorâmica da sutura palatina mediana mostrando tecido conjuntivo sutural (TC) delimitado por tecido ósseo (O) e (D) dente. B), C) e D) detalhe da sutura onde é possível verificar osso $(\mathbf{O})$ recoberto por osteoblastos delimitando a superfície óssea (setas pretas), fibras colágenas inseridas no tecido ósseo (FC) e vasos sanguíneos (V) por toda extensão do tecido sutural. Coloração H/E.

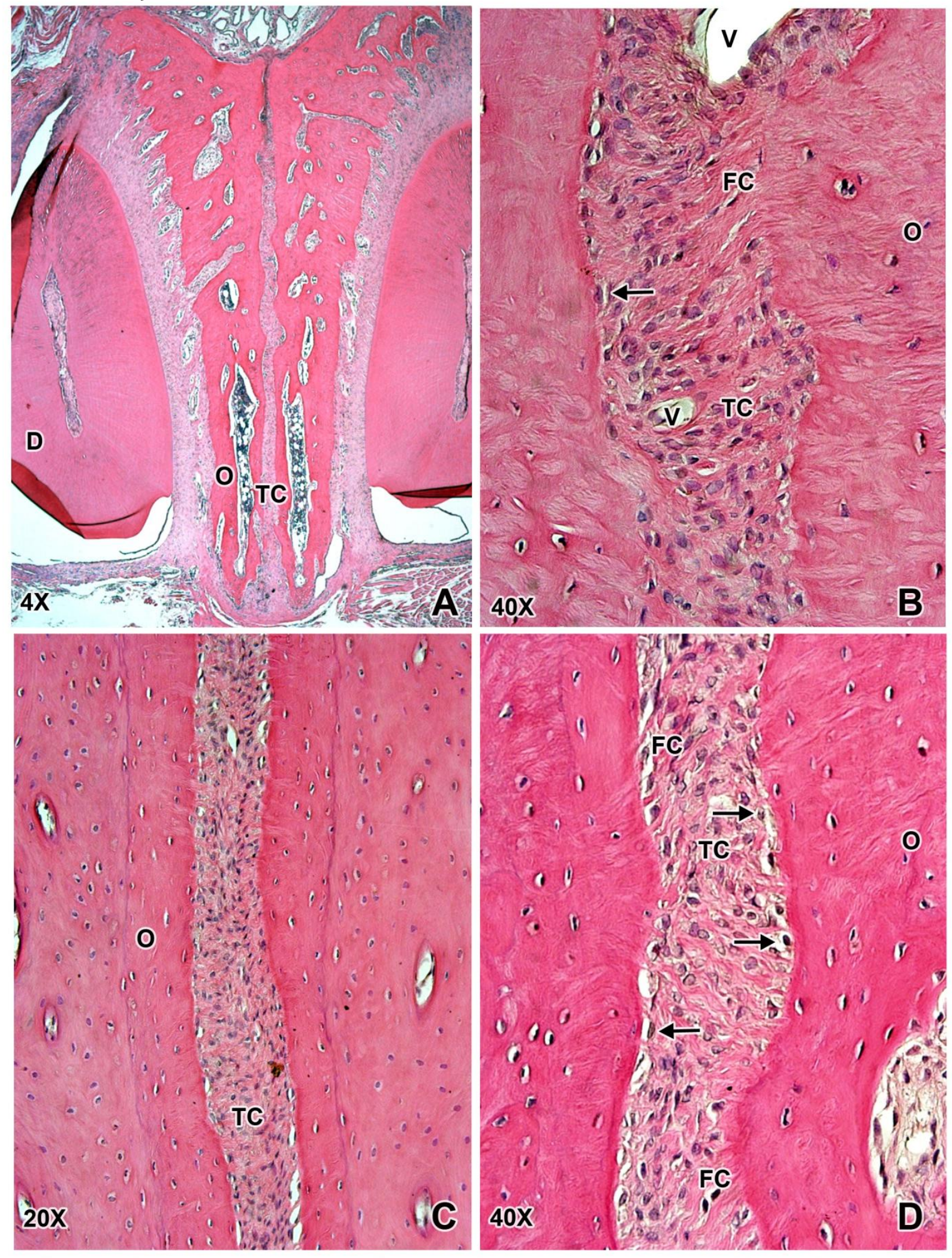



Figura 7- Região da sutura palatina mediana do grupo FC 7 dias corte frontal (A) e longitudinal (B, C, D), onde observa-se: A) visão panorâmica mostrando a sutura palatina mediana com tecido conjuntivo sutural (TC) delimitado por tecido ósseo (O). B), C) e D) detalhe da sutura onde é possível verificar osso (O) recoberto por osteoblastos delimitando a superfície óssea, (TC) tecido conjuntivo com numerosos fibroblastos e vasos sanguíneos (V) por toda extensão do tecido sutural. Coloração $\mathrm{H} / \mathrm{E}$ e Tricrômico de Masson.
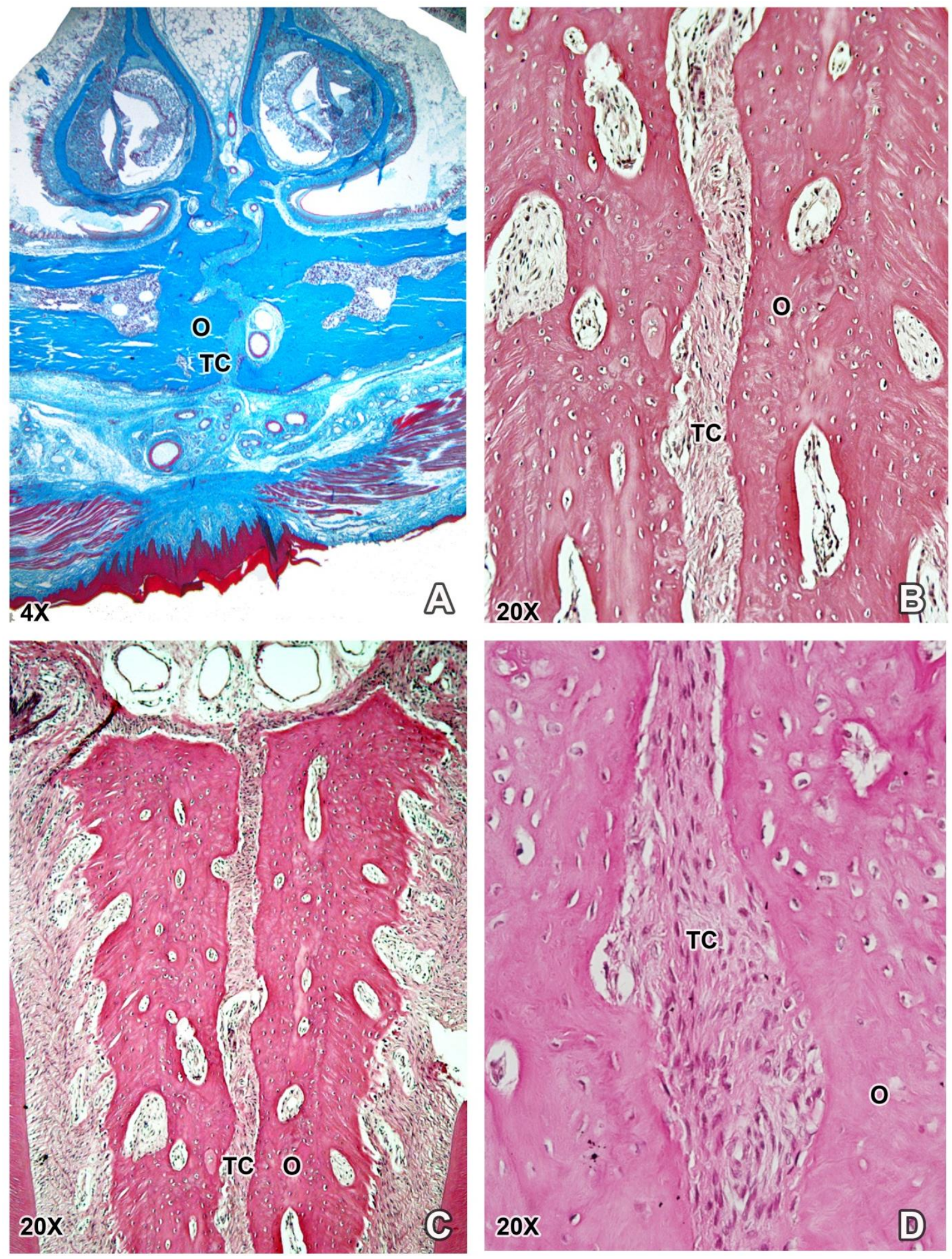

Figura 8- Região da sutura palatina mediana do grupo FC 21 dias corte frontal (A) e longitudinal (B, C, D), onde observa-se: A) visão panorâmica mostrando a sutura palatina mediana mostrando tecido conjuntivo sutural (TC) delimitado por tecido ósseo (O). B), C) e D) detalhe da sutura onde é possível verificar osso (0) recoberto por osteoblastos delimitando a superfície óssea (setas pretas), fibras colágenas inseridas no tecido ósseo (FC) e vasos sanguíneos (V) por toda extensão do tecido sutural. Coloração H/E e Tricrômico de Masson.
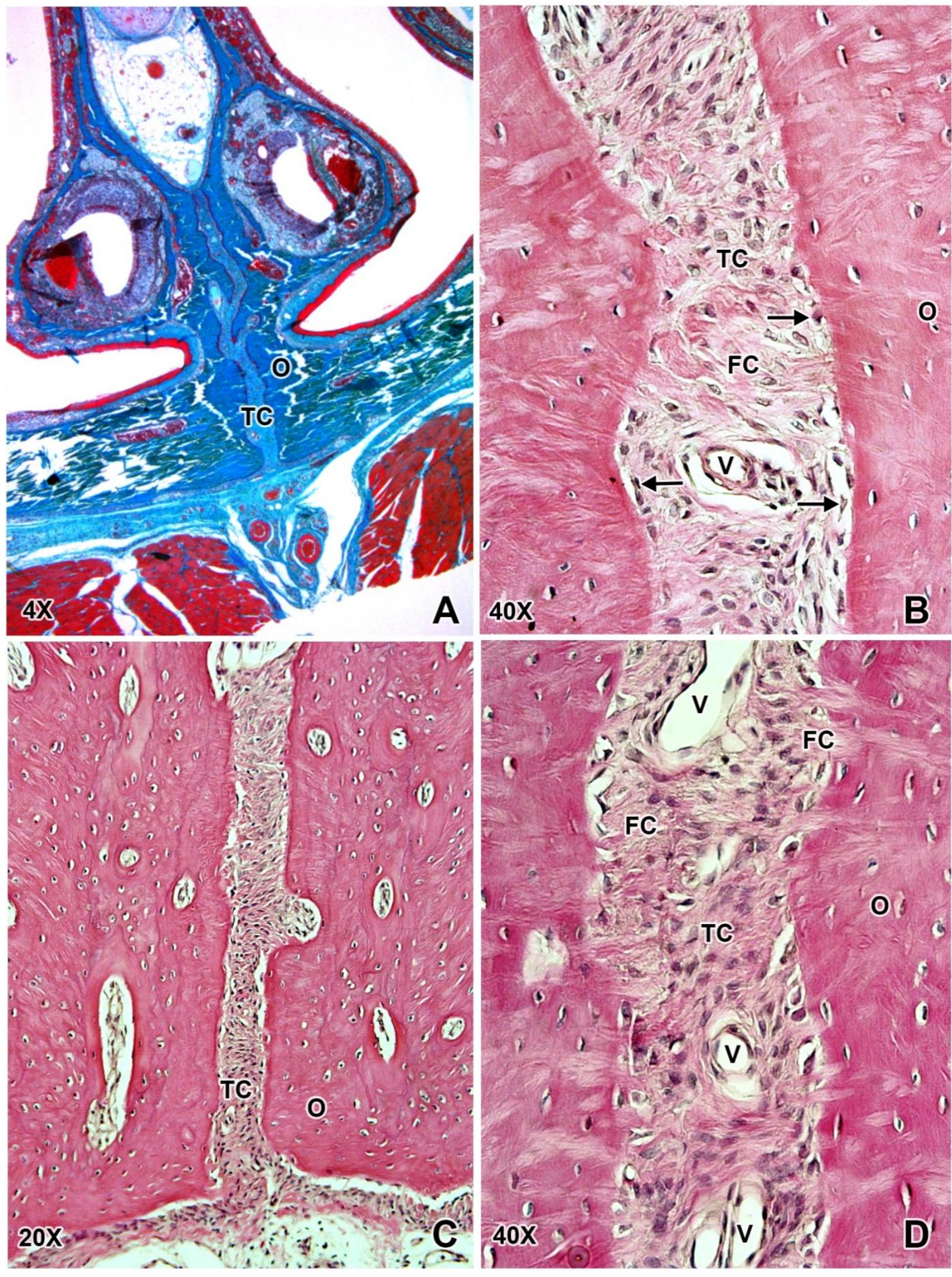



\subsubsection{Grupos Experimentais (ERM e ERM+FC)}

O procedimento de disjunção provocou mudanças expressivas nos componentes das estruturas da sutura palatina mediana, devido à grande intensidade da força ortopédica aplicada na região. Ao se aplicar a força sobre a coroa dos incisivos centrais superiores, pode-se observar a presença de áreas de pressão (faces distais dos incisivos) e de tração (faces mesiais dos incisivos) no ligamento periodontal, que resultou no movimento de inclinação dentária. No interior da sutura palatina mediana, notaram-se regiões típicas de força de tração. Microscopicamente, observou-se entre os incisivos a presença de um processo inflamatório no interior da gengiva marginal livre, principalmente no período de 7 dias no Grupo ERM+FC. Estes achados foram confirmados durante o exame clínico intrabucal.

Nos animais submetidos à fumaça de cigarro e à disjunção maxilar (ERM, $\mathrm{ERM}+\mathrm{FC}$ ) observaram-se diferenças histológicas nos períodos de avaliação. Desta maneira, as descrições histológicas foram apresentadas separadamente, além de serem ressaltadas algumas particularidades desses grupos.

\subsubsection{Grupo Expansão Rápida da Maxila (ERM)}

\section{a) $\underline{7 \text { dias }}$}

No terço anterior e médio do tecido sutural, pode-se observar grande proliferação vascular e a presença de alguns fibroblastos. Nesta área ainda havia neutrófilos (polimorfornucleares) e mononucleares, caracterizando que neste período ainda havia a presença de um infiltrado inflamatório nos dois terços anteriores da sutura palatina, porém em menor intensidade que o grupo ERM+FC. Os ossos de sustentação do tecido sutural caracterizavam-se por trabéculas ósseas remanescentes delgadas (Figura 9, página 73).

No terço médio, a superfície óssea próxima à sutura continha células pouco ativas. No lado oposto em direção às cavidades medulares, haviam numerosos osteoclastos, que estavam no interior das lacunas de Howship, dentro das cavidades medulares, o que caracterizava uma intensa reabsorção óssea solapante.

O terço posterior mostrou uma população celular semelhante aos dois terços anteriores, porém em menor quantidade. Por outro lado, os fibroblastos estavam mais numerosos e apresentavam fibras colágenas em desenvolvimento, além de se observar grande quantidade de vasos sanguíneos. Nesta região, as trabéculas 
remanescentes estavam levemente mais espessas e com os osteócitos preservados em suas lacunas. A reabsorção óssea foi bem caracterizada quando da visualização das linhas reversas no interior do tecido. (Figura 9, página 73).

\section{b) 21 dias}

No grupo de animais de 21 dias pós-disjunção, o espaço sutural foi preenchido com tecido ósseo neo-formado de tal forma que se assemelhou ao grupo Controle, e o tecido sutural estava bastante celularizado em toda a sua extensão. Notaram-se numerosos vasos sangüíneos, fibroblastos e grande quantidade de osteoblastos neste período. As células da superfície óssea sutural eram volumosas em vários pontos indicando atividade de síntese. As fibras colágenas penetravam no tecido ósseo mostrando feixes espessos e repletos de fibroblastos (Figura 10, página 75).

\subsubsection{Grupo Expansão Rápida da Maxila e Fumaça de Cigarro (ERM+FC)}

\section{a) 7 dias}

Após 7 dias do procedimento de ERM e exposição à fumaça de cigarro, pode-se observar o afastamento das margens ósseas suturais das hemi-maxilas. Parte do tecido sutural se manteve aderido às margens ósseas, porém pode-se notar que havia uma parte do tecido sutural rompido e destacado das margens ósseas. Estes fragmentos destacados foram envoltos por diversos neutrófilos (Figura 11, página 77).

Um pequeno segmento da região anterior da maxila apresentou um tecido sutural aderido e totalmente amorfo (cor roxa devido à autólise das células). As trabéculas ósseas nesta região exibiram lacunas vazias, sem osteócitos, coradas em roxo mostrando novamente a autólise celular ou invasão por neutrófilos. Principalmente no terço anterior e médio da sutura, observaram-se áreas inflamatórias contendo monócitos, neutrófilos e linfócitos. Nesta região, o tecido sutural remanescente estava alterado, apresentando células contraídas, com núcleos irregulares e picnóticos, fibras colágenas desorganizadas. Áreas hemorrágicas com proliferação vascular também foram evidentes durante este período (Figura 11, página 77).

No terço posterior pode-se notar a predominância de diversas áreas hemorrágicas com hemácias e grande quantidade de vasos hiperêmicos. Esta 
hemorragia era proveniente das cavidades medulares adjacentes ao tecido sutural. Ainda na região posterior, era possível encontrar áreas inflamatórias, porém em menor quantidade, além de se observar um tecido conjuntivo aderido ao tecido ósseo com suas fibras colágenas em diversos sentidos (Figura 11, página 77).

b) 21 dias

No grupo de animais de 21 dias pós-disjunção e exposição à fumaça de cigarro, as características histológicas mostraram-se atrasadas em relação ao grupo submetido apenas à ERM, principalmente em relação à formação óssea. $O$ espaço sutural ainda não apresentava uma largura uniforme em sua extensão, porém a superfície óssea estava recoberta por osteoblastos e foi possível observar uma linha de repouso separando o tecido ósseo recém-formado do tecido antigo. Algumas áreas de remodelação óssea com osteoclastos em lacunas de Howship caracterizando a reabsorção óssea frontal ainda foram encontradas. As células da superfície óssea sutural eram volumosas em vários pontos indicando atividade de síntese. Proliferação vascular e de fibras colágenas estavam evidentes (Figura 12, página 79). 

Figura 9- Região da sutura palatina mediana do grupo ERM 7 dias cortes longitudinais (A, B, C, D), onde observa-se: A) visão panorâmica da sutura palatina mediana mostrando tecido conjuntivo sutural com algumas áreas inflamatórias presentes no tecido conjuntivo (TC) delimitado por tecido ósseo (O) e (D) dente. B), C) e D) Detalhe da sutura onde é possível verificar osso imaturo com contorno irregular (0) recoberto por osteoblastos ativos delimitando a superfície óssea (setas pretas). Coloração H/E e Tricrômico de Masson.

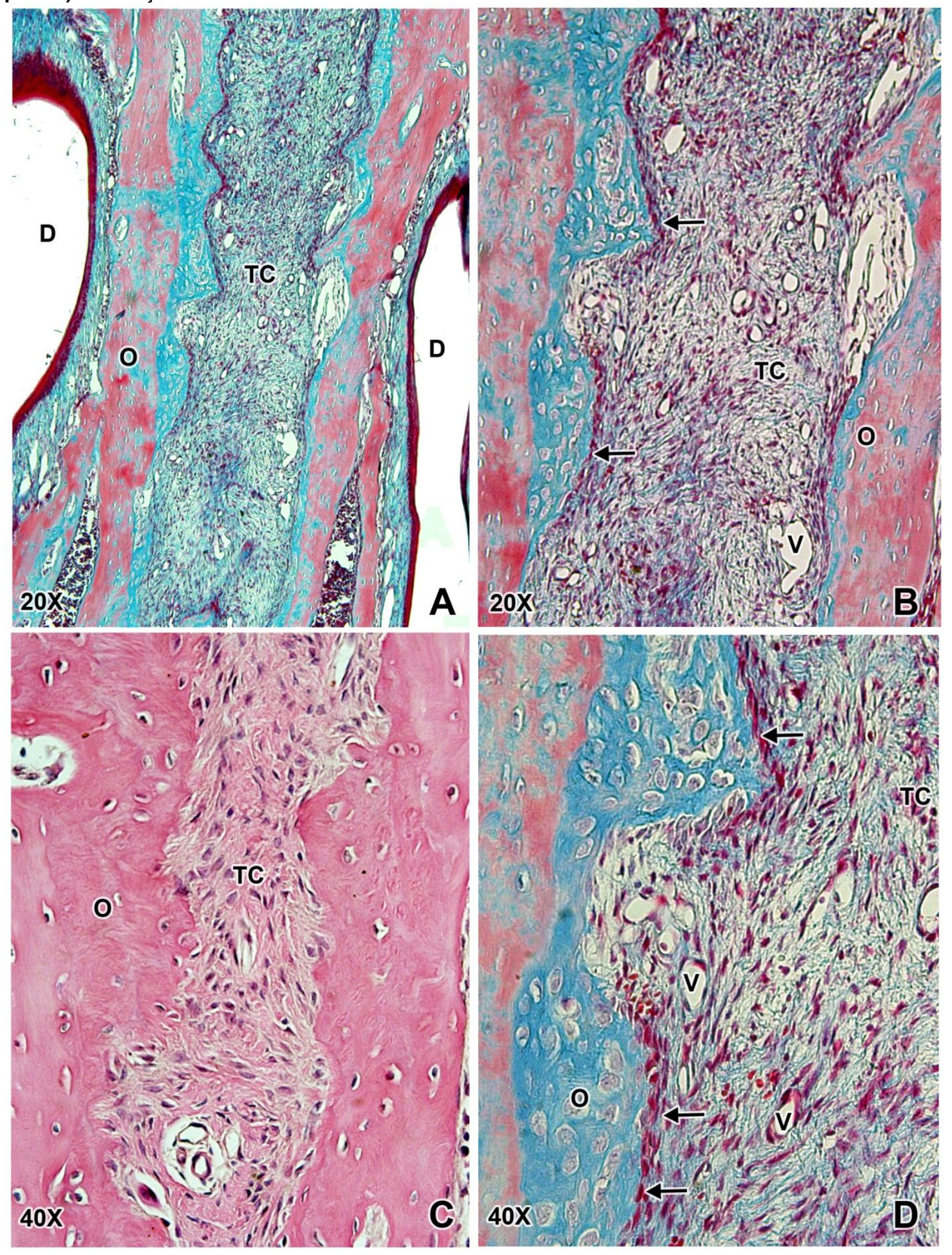



Figura 10- Região da sutura palatina mediana do grupo ERM 21 dias cortes longitudinais (A, B, C, D), onde observa-se: A) visão panorâmica da sutura palatina mediana mostrando tecido conjuntivo sutural (TC) delimitado por tecido ósseo (O) e (D) dente. B), C) e D) Detalhe da sutura onde é possível verificar osso $(\mathbf{O})$ recoberto por osteoblastos delimitando a superfície óssea (setas pretas), fibras colágenas inseridas no tecido ósseo (FC) e vasos sanguíneos (V) por toda extensão do tecido sutural. Coloração H/E e Tricrômico de Masson.

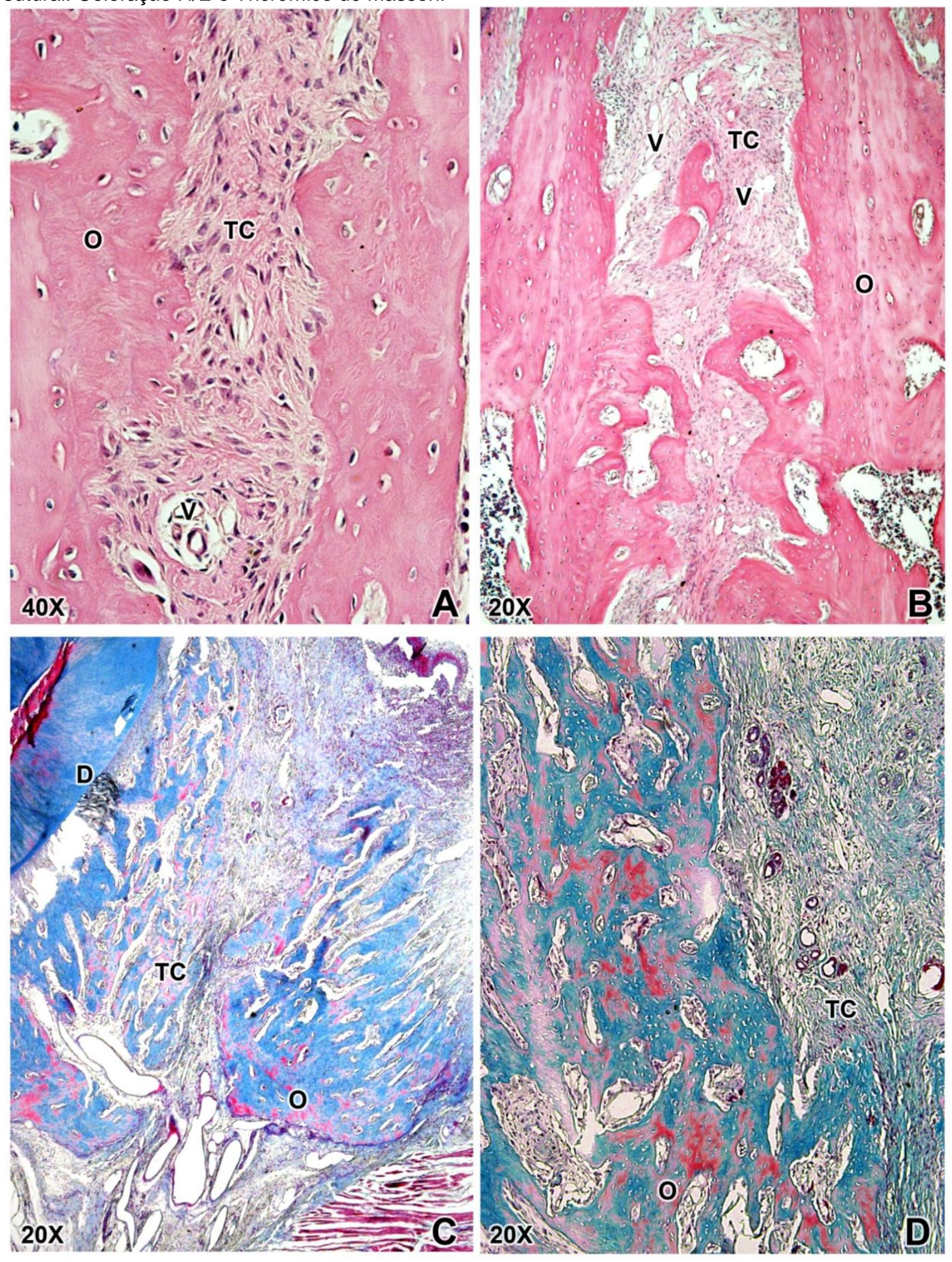



Figura 11- Região da sutura palatina mediana do grupo ERM+FC 7 dias cortes longitudinais (A, B, C, D), onde observa-se: A) visão panorâmica da sutura palatina mediana mostrando tecido conjuntivo sutural com áreas hemorrágicas (*)no tecido conjuntivo (TC) delimitado por tecido ósseo (O) e (D) dente. B), C) e D) Detalhe da sutura onde é possível verificar osso (0) recoberto por osteoblastos delimitando a superfície óssea (setas pretas), áreas hemorrágicas $\left({ }^{*}\right)$ e inflamação (I) por toda extensão do tecido sutural. Proliferação vascular (V) estava presente. Coloração Tricrômico de Masson.
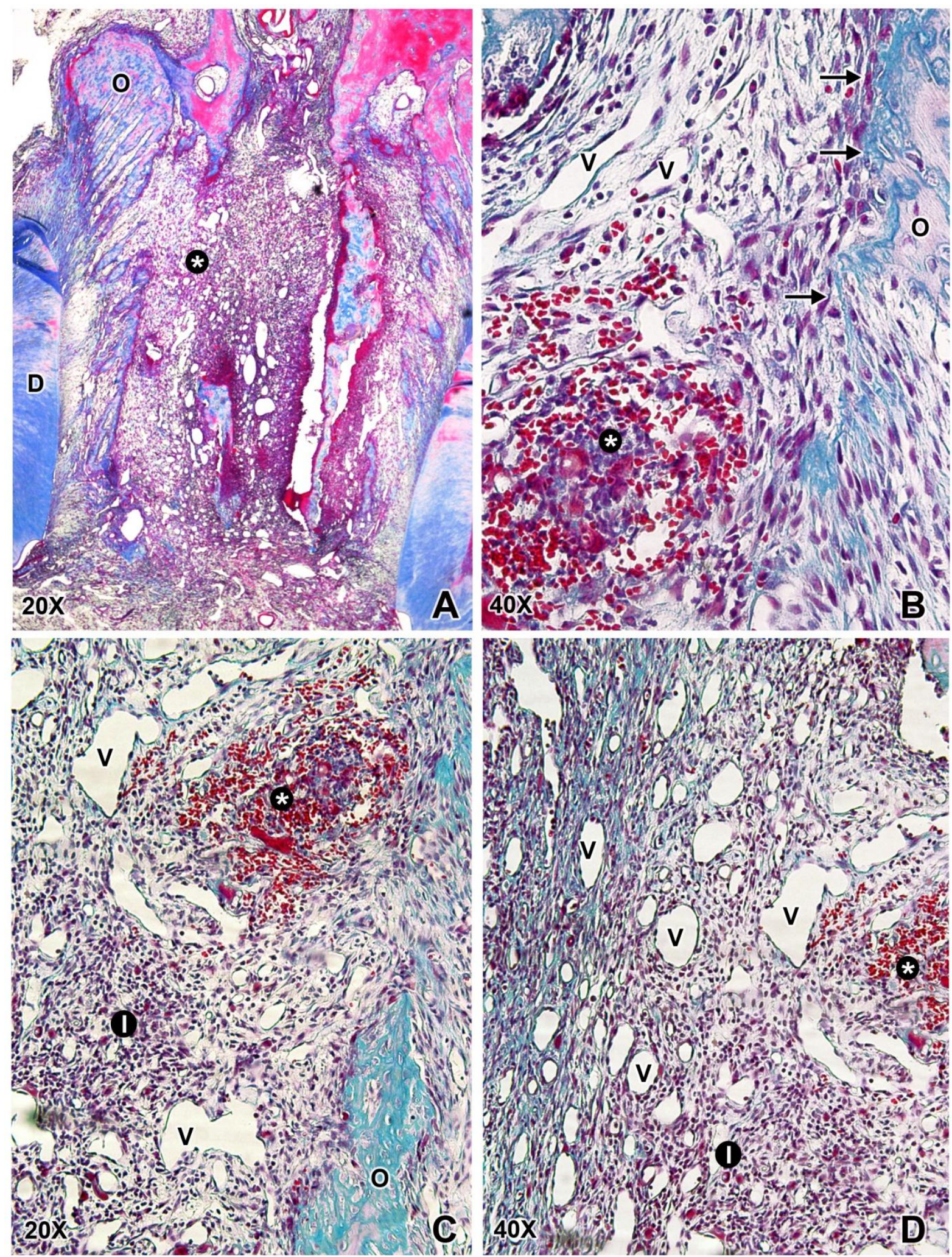

Figura 12- Região da sutura palatina mediana do grupo ERM+FC 21 dias corte frontal (A), e cortes longitudinais B, C, D), onde observa-se: A) visão panorâmica da sutura palatina mediana mostrando tecido conjuntivo sutural (TC) delimitado por tecido ósseo (O) e (D) dente. B), C) e D) Detalhe da sutura onde é possível verificar trabéculas de tecido ósseo (O) espalhadas no tecido conjuntivo (FC) e vasos sanguíneos (V) por toda extensão do tecido sutural. Coloração H/E.

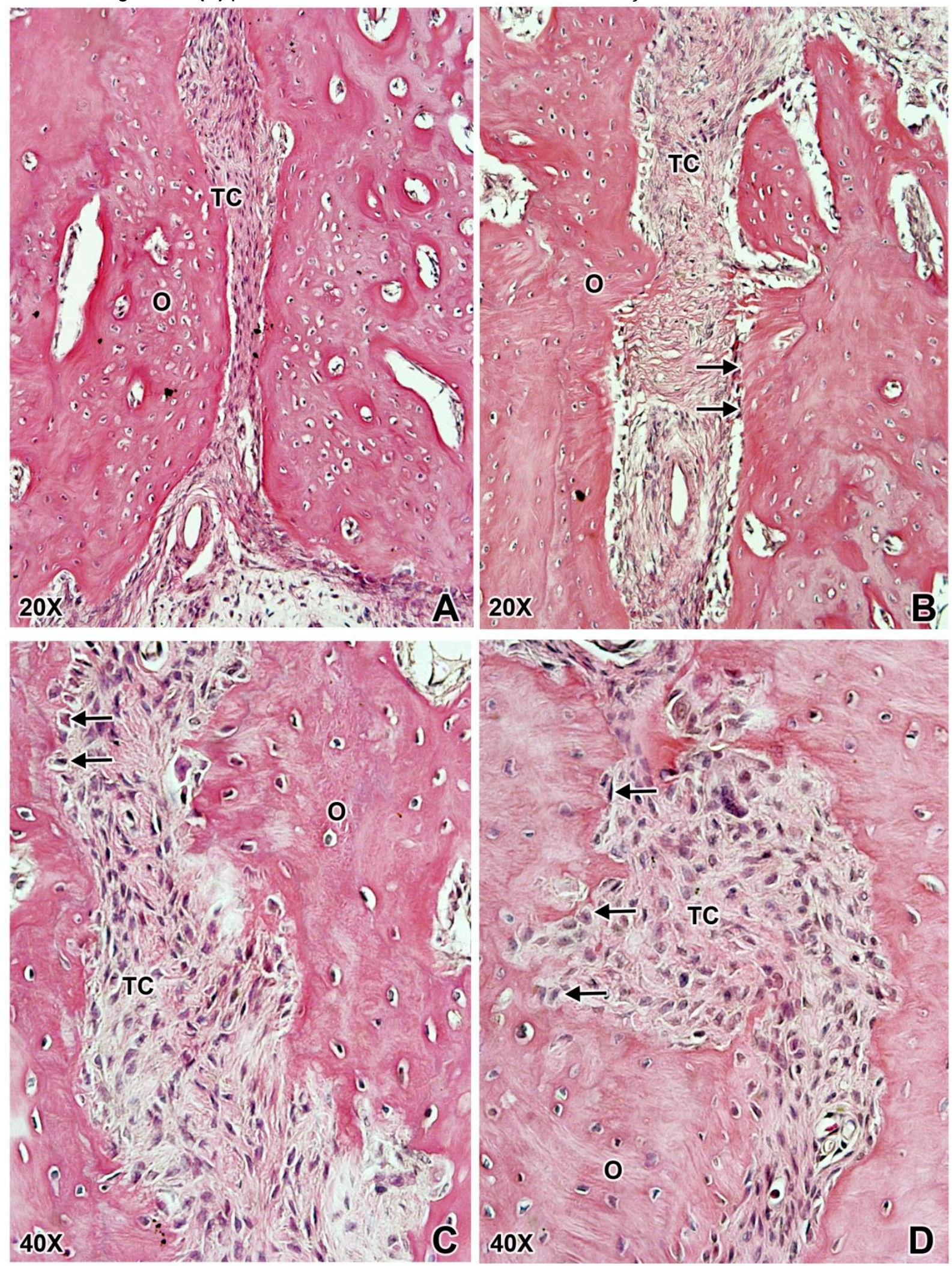





\section{4 qRT-PCR}

Observou-se diferença estatisticamente significante em relação ao tempo e tratamento quando foi analisada a expressão relativa dos RNAm dos genes Tnfrsf11a (Rank), Tnfsf11 (Rankl) e Tnfrsf11b (Opg), Bmp-2 (Bmp2), lbsp (Bsp), Sparc (Onc) e Bglap (Occ), $(p<0,05)$. Entretanto não se observou diferença estatística na expressão gênica do Spp1 (Opn), quando se analisaram os diferentes tratamentos para cada tempo de avaliação $(p>0,05)$, apenas foi encontrada diferença quando se avaliaram os diferentes tempos para cada grupo de estudo $(p<0,05)$. Abaixo foram descritos minuciosamente os resultados para cada gene de interesse envolvido no processo de remodelação óssea.

\section{a) Expressão de RNAm de Tnfrsf11a (Rank)}

Nos períodos analisados o grupo ERM apresentou maior expressão de mRNA para o gene Tnfrsf11a (Rank) quando comparado ao grupo Controle $(p<0,05)$. O grupo $E R M+F C$ também apresentou um aumento significativo em relação ao Grupo Controle $(p<0,05)$. No grupo FC não houve diferença entre os tempos analisados quando comparado ao grupo Controle ( $>0,05)$ (Figura 13A).

Ao se avaliar os dois grupos experimentais (ERM e ERM+FC) no grupo ERM observou-se maior expressão gênica estatisticamente significante em todos os períodos experimentais $(p<0,05)$. Para o grupo ERM, notou-se uma maior expressão aos 14 dias comparado ao tempo de 3 dias $(p<0,05)$ (Figura 13B).

Figura 13- (A) Expressão do RNAm do gene Tnfrs11a (Rank) nos diferentes grupos em comparação ao grupo controle e (B) Comparação entre os dois grupos experimentais. Os gráficos mostram média, desvio padrão. ${ }^{*} p<0,05,{ }^{* *} p<0,01$. ${ }^{* * *} p<0,001$.

Tnfrsf11a (Rank)

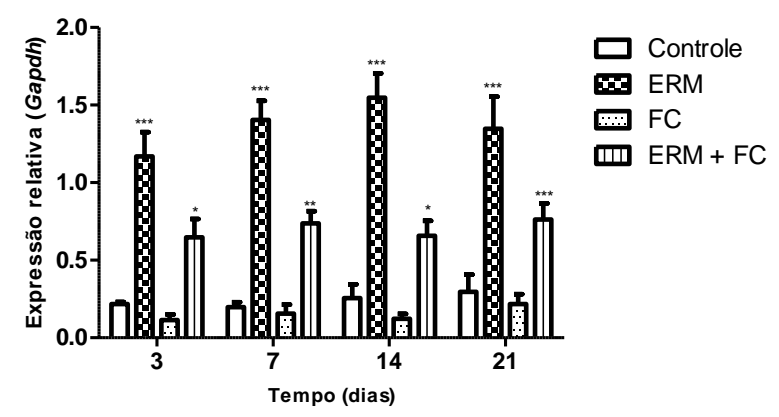

Tnfrsf11a (Rank)

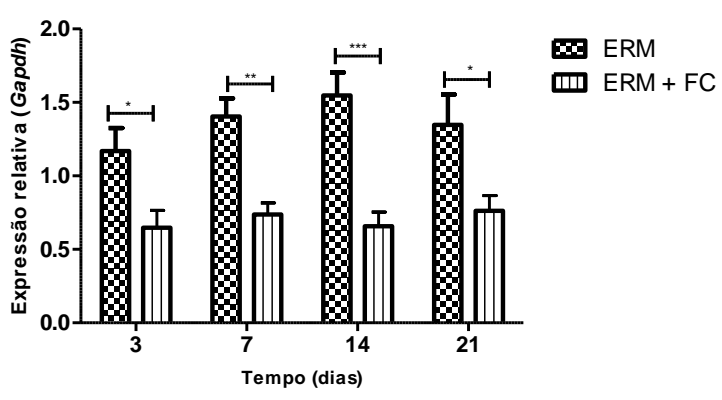




\section{b) Expressão de RNAm de Tnfsf11 (Rank!)}

$\mathrm{Na}$ análise gênica, o grupo ERM apresentou maior expressão de mRNA para o gene Tnfsf11 (Rankl) quando comparado ao grupo Controle, FC e ERM+FC em todos os períodos, sendo este aumento significativo também em todos os períodos quando comparado ao grupo Controle $(p<0,001)$. No período de 21 dias, observouse que o grupo ERM apresentou uma redução na expressão gênica quando comparado aos outros tempos experimentais, porém ainda houve aumento significativo comparado ao seu controle $(p<0,001)$ (Figura 14A).

$A$ avaliação dos dois grupos experimentais (ERM e ERM+FC) indicou um aumento na expressão gênica de Rankl para o grupo ERM em todos os tempos estudados, sendo este aumento significativo aos 7 e 14 dias $(p<0,05)$ (Figura 14B).

Figura 14- (A) Expressão do RNAm do gene Tnfrs11 (Rankl) nos diferentes grupos em comparação ao grupo controle e (B) Comparação entre os dois grupos experimentais. Os gráficos mostram média, desvio padrão. ${ }^{*} p<0,05,{ }^{* *} p<0,01 .{ }^{* * *} p<0,001$.
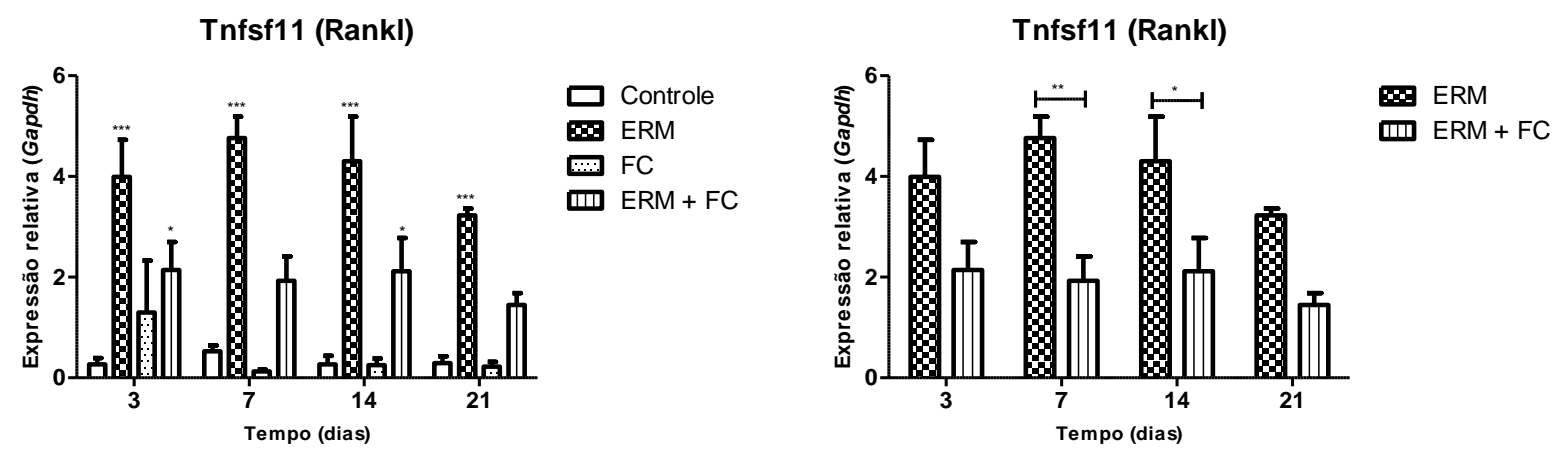


\section{c) Expressão de RNAm de Tnfrsf11b (Opg)}

O grupo ERM apresentou um estímulo na expressão de RNAm para o gene Tnfrsf11b (Opg) quando comparado aos demais grupos nos períodos de 7, 14 e 21 dias de estudo $(p<0,001)$ (Figura 15A).

Quando se comparou os dois tipos de grupos experimentais, pode-se observar uma maior expressão de RNAm para Opg no grupo ERM comparado ao grupo ERM+FC com significância estatística a partir dos 7 dias de avaliação (Figura 15B).

Figura 15- (A) Expressão do RNAm do gene Tnfrsf11b (Opg) nos diferentes grupos em comparação ao grupo controle e (B) Comparação entre os dois grupos experimentais. Os gráficos mostram média, desvio padrão. ${ }^{*} p<0,05,{ }^{* \star} p<0,01$. ${ }^{* \star *} p<0,001$.
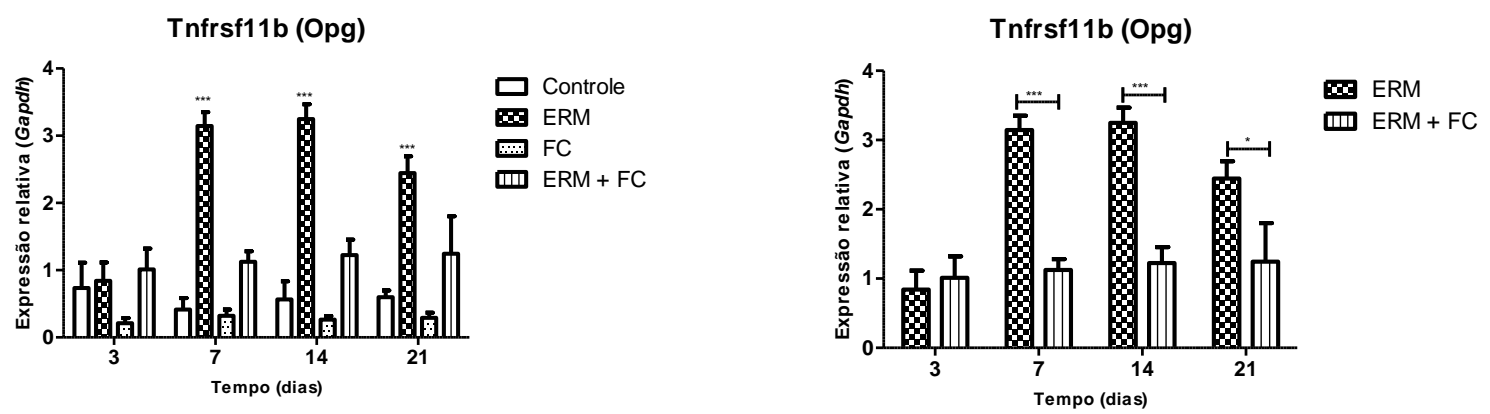


\section{d) Expressão de RNAm de Bmp2}

$\mathrm{Na}$ análise da expressão gênica nos diferentes grupos de estudo, notou-se que no período de 3 dias não houve diferença estatística na expressão do gene $B m p-2$ entre os diferentes tratamentos $(p>0,05)$. Nos demais períodos houve um aumento estatisticamente significante na expressão relativa deste gene no grupo ERM comparado ao grupo Controle $(p<0,05)$ (Figura 16A).

Ao se analisar os dois grupos experimentais (ERM e ERM+FC) nos diferentes tempos de estudos, pode-se observar que houve uma maior expressão de Bmp-2 no grupo ERM em todos os períodos, com diferença estatística aos 14 e 21 dias $(p<0,05)$. O pico de maior expressão de Bmp-2 do grupo ERM foi aos 21 dias (Figura 16B).

Figura 16- (A) Expressão do RNAm do gene Bmp-2 nos diferentes grupos em comparação ao grupo controle e (B) Comparação entre os dois grupos experimentais. Os gráficos mostram média, desvio padrão. ${ }^{*} p<0,05,{ }^{* *} p<0,01 .{ }^{* *} p<0,001$.

Bmp-2

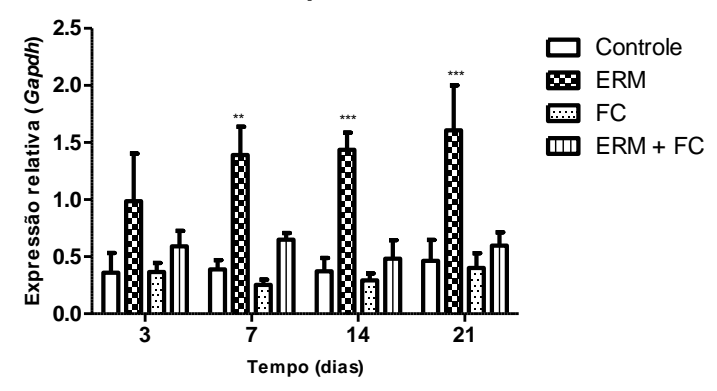

Bmp-2

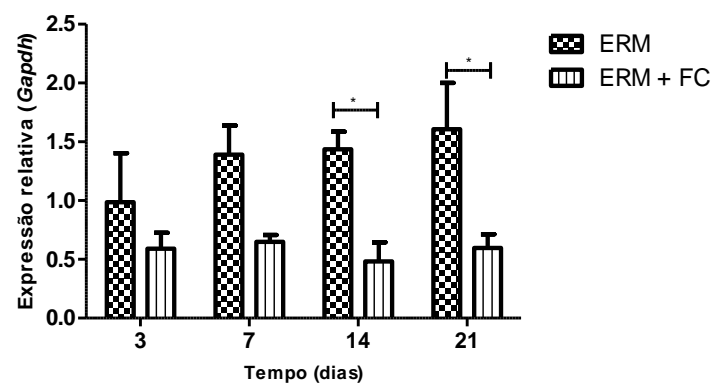




\section{e) Expressão de RNAm de Ibsp (Bsp)}

$\mathrm{Na}$ análise da expressão gênica, o grupo ERM apresentou estímulo na expressão de RNAm para o gene Ibsp (Bsp) quando comparado ao grupo Controle $(p<0,001)$ nos períodos de 3,7 e 14 dias. No período de 21 dias, houve uma redução na expressão gênica de lbsp em todos os grupos analisados $(p<0,05)$ (Figura 17A).

Ao se analisar os dois grupos experimentais (ERM e ERM+FC) nos diferentes tempos de estudo, pode-se observar um estímulo na expressão de lbsp no grupo ERM aos 3, 7 e 14 dias, sendo este aumento significativo apenas aos 3 e 14 dias $(p<0,001)$. No período final de observação (21 dias) houve uma redução da expressão de lbsp nos dois grupos analisados. (Figura 17B).

Figura 17- (A) Expressão do RNAm do gene Ibsp (Bsp) nos diferentes grupos em comparação ao grupo controle e (B) Comparação entre os dois grupos experimentais. Os gráficos mostram média, desvio padrão. ${ }^{*} p<0,05,{ }^{* *} p<0,01 .{ }^{* * *} p<0,001$.

Ibsp (Bsp)

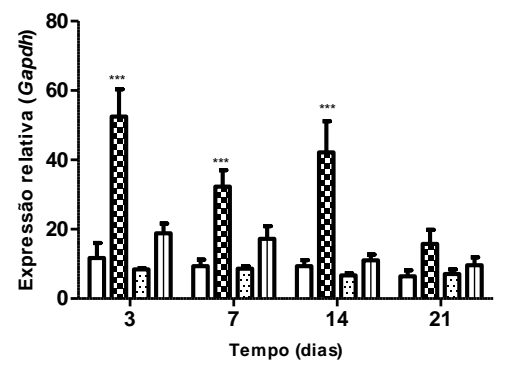

Ibsp (Bsp)

$\square$ Controle
ERM
I FC
四 ERM + FC

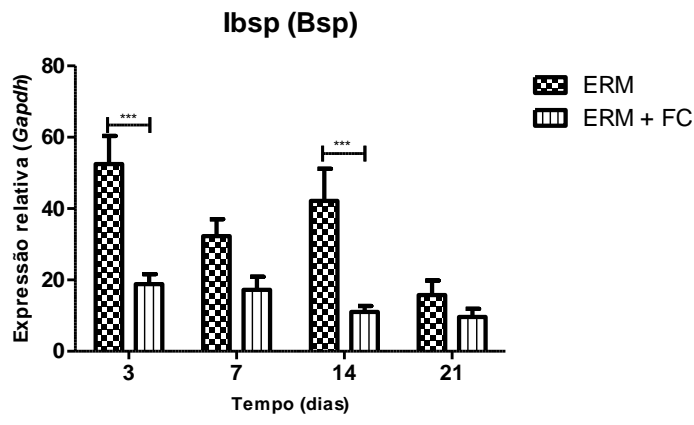




\section{f) Expressão de RNAm de Sparc (Onc)}

$\mathrm{Na}$ análise gênica dos períodos de 3, 7 e 14 dias de remodelação óssea, o grupo ERM apresentou maior expressão de RNAm para o gene Sparc (Onc) quando comparado ao Controle $(\mathrm{p}<0,05)$, porém no grupo de 21 dias observou-se padrão inverso, em que foi notada uma redução na expressão desse gene em todos os grupos analisados. Avaliando-se o período mais tardio do processo de remodelação óssea, pode-se observar que houve uma menor expressão do gene de interesse em todos os grupos comparado aos períodos anteriores (Figura 18A).

Quando avaliou-se o tempo nos dois grupos experimentais (ERM e $E R M+F C$ ), pode-se observar que o grupo ERM apresentou estímulo do gene de interesse aos 3,7 e 14 dias quando comparado ao grupo ERM+FC $(p<0,001)$ (Figura 18B).

Figura 18- (A) Expressão do RNAm do gene Sparc (Onc) nos diferentes grupos em comparação ao grupo controle e (B) Comparação entre os dois grupos experimentais. Os gráficos mostram média, desvio padrão. ${ }^{*} p<0,05,{ }^{* *} p<0,01 .{ }^{* * *} p<0,001$.
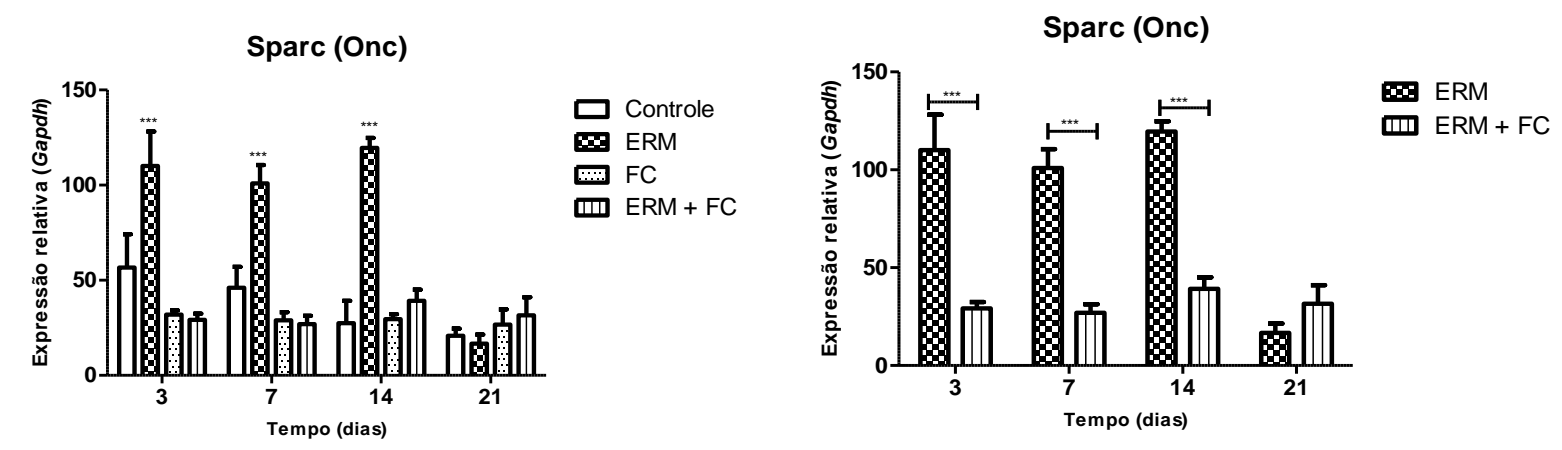


\section{g) Expressão de RNAm de Bglap (Occ)}

Os períodos de 3, 7 e 14 dias de reparo ósseo do grupo ERM apresentaram a maior expressão de RNAm para o gene Bglap (Occ) quando comparado ao grupo Controle $(p<0,05)$. No período de 21 dias observou-se uma diminuição na expressão deste gene no grupo ERM, mas esta redução não foi significativa comparada ao Controle $(p<0,05)$ (Figura 19A).

Ao se avaliar os dois grupos experimentais (ERM e ERM+FC) observou-se que o grupo ERM+FC apresentou uma inibição gênica para Occ em todos os períodos $(p<0,05)$. O grupo ERM mostrou um estímulo para o gene de interesse até aos 14 dias de reparo ósseo $(p<0,05)$ (Figura 19B).

Figura 19- (A) Expressão do RNAm do gene Bglap (Occ) nos diferentes grupos em comparação ao grupo controle e (B) Comparação entre os dois grupos experimentais. Os gráficos mostram média, desvio padrão. ${ }^{*} p<0,05,{ }^{* *} p<0,01$. ${ }^{* *} p<0,001$.
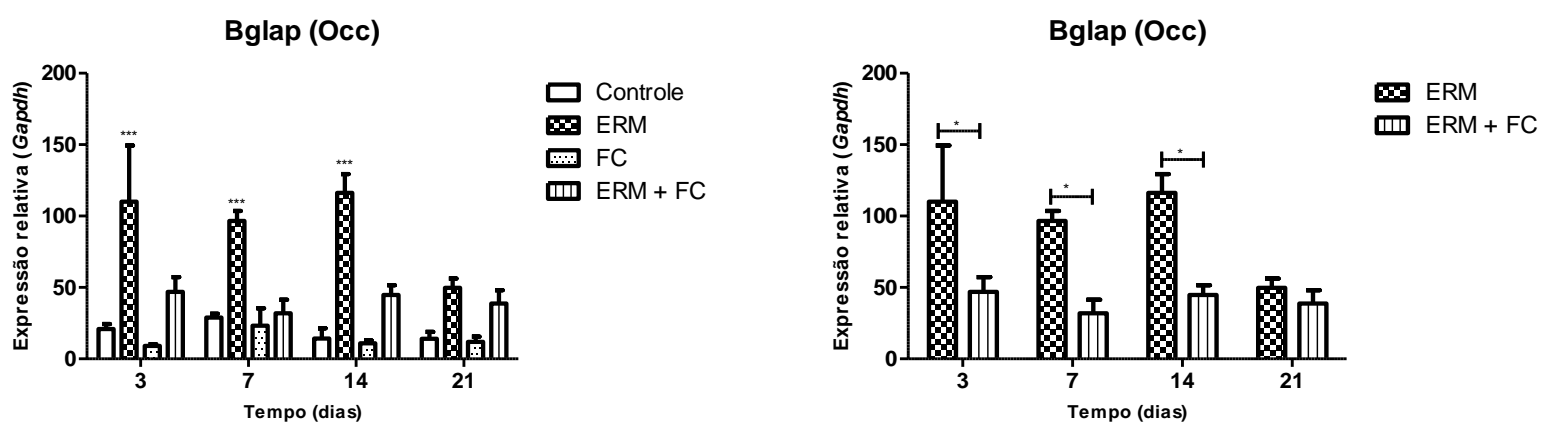


\section{h) Expressão de RNAm de Spp1 (Opn)}

Ao se analisar os diferentes grupos em cada tempo, pode-se notar que em todos os períodos de observação, o grupo ERM e ERM+FC apresentaram um estímulo na expressão de RNAm para o gene Spp1 (Opn) quando comparado aos grupos Controle e FC, porém só no grupo ERM este aumento foi significativo $(p<0,05)$ (Figura 20A).

$\mathrm{Na}$ análise entre os dois grupos experimentais (ERM e ERM+FC), pode-se observar que o grupo ERM teve um estímulo na expressão gênica de Opn em todos os períodos, porém este aumento não foi significativo em relação ao grupo $E R M+F C$ $(p<0,05)$. (Figura 20B).

Figura 20- (A) Expressão do RNAm do gene Spp1 (Opn) nos diferentes grupos em comparação ao grupo controle e (B) Comparação entre os dois grupos experimentais. Os gráficos mostram média, desvio padrão. ${ }^{*} p<0,05,{ }^{* *} p<0,01 .{ }^{* * *} p<0,001$.

Spp1 (Opn)

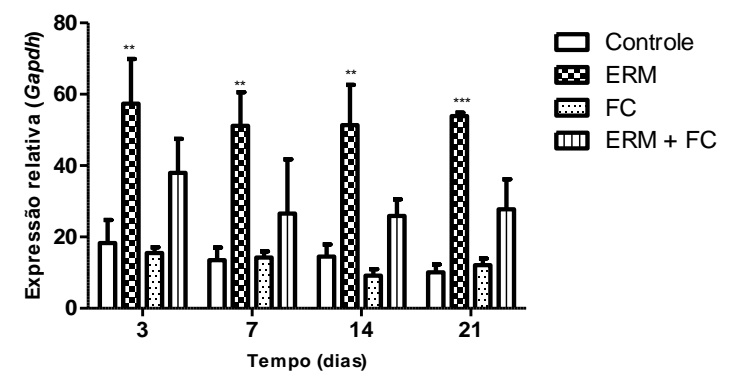

Spp1 (Opn)

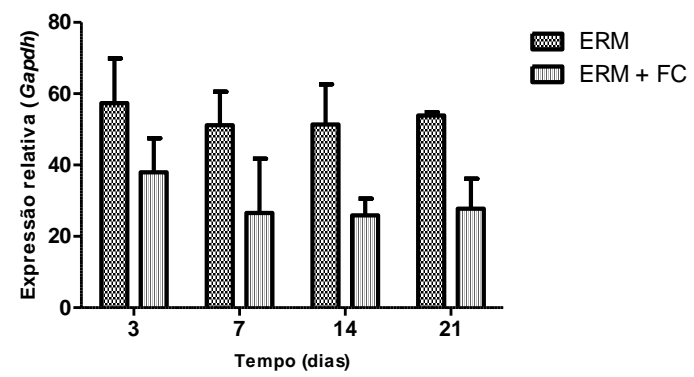


5. Discussão 



\section{DISCUSSÃO}

Embora as campanhas anti-fumo sejam promovidas constantemente por diversos órgãos de saúde, ainda é significativa a parcela da população que possui o hábito de fumar. Além de ser a causa de muitas doenças fatais e mortes prematuras em diversos países (Doll et al., 2004), a fumaça do cigarro tem efeitos prejudiciais no sistema imunológico (Wong et al., 2007; Stampli e Anderson, 2009) e é extremamente nociva em virtude dos 50 componentes conhecidamente carcinogênicos que a constituem (Oberg et al., 2011). É descrito na literatura o prejuízo causado no processo de reparo tecidual por alguns elementos da fumaça de cigarro como a nicotina, o monóxido de carbono e o cianeto (Silverstein, 1992; Haverstoch e Mandracchia, 1998), bem como o efeito negativo observado in vitro pela ação da acroleína e do acetaldeído na proliferação e adesão de células importantes para o processo de cicatrização, como os fibroblastos (Cattaneo et al., 2000). Considerando-se que a remodelação periodontal resultante da movimentação dentária envolve o recrutamento de diversos mediadores inflamatórios (Hughes, 2000; Garlet et al., 2007), é razoável acreditar que mudanças na resposta ao tratamento ortodôntico/ortopédico devam ocorrer em pacientes expostos à inalação da fumaça de cigarro.

A ERM ou disjunção maxilar é um procedimento ortopédico que visa tratar a mordida cruzada posterior dental, esquelética ou associação de ambas, além de ser indicada para corrigir diversas discrepâncias antero-posteriores associadas ou não a mordida cruzada posterior. A prevalência de mordida cruzada varia em torno de $3 \%$ a $24 \%$ (Reddy et al., 2013; Carvalho et al., 2013; Kumar et al., 2013). É importante que seja realizada correção ortodôntica precoce neste tipo de maloclusão, pois há prejuízo do crescimento e desenvolvimento crânio-maxilo-facial (Ong et al., 2013; Zandi et al., 2014). O conhecimento e o entendimento sobre as alterações provocadas pela inalação da fumaça de cigarro no processo de remodelação óssea associado à instalação de forças mecânicas ainda é extremamente escasso e complexo, o que torna os efeitos do tratamento ortodôntico destes pacientes bastante imprevisível.

Dessa forma, foi realizada neste estudo a avaliação dos principais mediadores moleculares envolvidos no processo de remodelação óssea após ERM em ratos submetidos à inalação da fumaça de cigarro. A utilização de ratos como animais de estudo oferece a oportunidade de avaliar o processo de remodelação óssea intramembranosa em diversas condições patológicas, além de proporcionar menos interferências de fatores de confusão, que podem estar presentes em humanos.

O modelo de remodelação óssea utilizado neste estudo, associado à ERM in vivo, foi previamente descrito na literatura (Sawada e Shimizu, 1996; Saito e Shimizu, 1997; 
Silva et al., 2012; Arnez et al., 2017) e demonstrou ser um sistema efetivo para a separação maxilar na sutura palatina mediana, por isso foi utilizado para avaliar os efeitos da fumaça de cigarro passiva sobre a remodelação e neoformação óssea. O tempo de 3 semanas de exposição prévia à fumaça a que os animais foram submetidos, anterior à realização de ERM, foi definido com o objetivo de avaliar os efeitos crônicos da fumaça no metabolismo ósseo (Pinto et al., 2002; Santiago et al., 2017), tendo em vista que o turnover ósseo dos roedores dura em torno de 21 dias para ocorrer.

O procedimento de ERM é empregado para correção da mordida cruzada posterior, em que se observa o afastamento dos ossos palatinos em direção lateral, a abertura da sutura palatina mediana e o aparecimento de um diastema entre os incisivos centrais superiores. As forças mecânicas são transmitidas para o microambiente da matriz extracelular, levando à modificações na membrana celular, citoesqueleto, síntese de proteínas da matriz nuclear e alterações no padrão de expressão gênica (Krishnan e Davidovitch, 2006). As mudanças na expressão gênica frente a forças mecânicas podem modular positiva ou negativamente a viabilidade, proliferação e a diferenciação celular, que são essenciais para o mecanismo de movimentação ortodôntica (Meikle, 2006).

As células eucarióticas expressam informações genéticas baseada no princípio fundamental da biologia molecular. Este princípio consiste no fato de que uma sequência de nucleotídeos de uma região específica da molécula de DNA em um cromossomo é inicialmente copiada sob a forma de RNA durante o processo de transcrição. As cópias de RNA, chamadas de moléculas de RNAm, provenientes de segmentos de DNA, são utilizadas como moldes para a síntese proteica durante o processo de tradução. A transcrição do DNA em RNAm dos eucariotos é realizada pela enzima RNA polimerase II. Os RNAms processados dentro do núcleo são transportados para o citoplasma celular e, após maturação, são traduzidos em proteínas pelos ribossomos. A transcrição e a tradução são os meios pelos quais se estuda a expressão gênica das diferentes células (Alberts et al., 2010).

O padrão de expressão gênica celular pode ser alterado em resposta a mudanças em seu meio ambiente. Uma célula pode regular a expressão de cada um de seus genes de acordo com a sua necessidade, por meio do controle da produção de seus RNAs ou pela capacidade de alterar seus níveis proteicos (Alberts et al., 2010). Contudo, é necessário esclarecer que o RNAm de genes estimulados ou inibidos nem sempre correspondem ao mesmo perfil proteico. A expressão gênica pode ser regulada em diferentes etapas no caminho que vai do DNA ao RNA até a produção de proteínas. Há uma complexidade de eventos que podem modular a expressão de diferentes genes e proteínas nas células. Desta maneira, torna-se importante enfatizar que existem diversos mecanismos para regulação da expressão gênica, tais como (1) controle transcricional 
(controlando quando e como um determinado gene pode ser transcrito), (2) controle póstranscricional, isto é, controle do processamento de RNA, transporte de RNA e controle da sua localização no citoplasma, (3) controle traducional, (4) controle da degradação do RNAm e (5) controle da atividade proteica (Alberts et al., 2010).

Assim, os processos de regulação gênica e tradução proteica não necessariamente são o reflexo um do outro. No modelo utilizado no presente estudo, o padrão de formação ou reabsorção óssea observados histologicamente deve ser interpretado juntamente com os resultados obtidos em nível molecular. Isto porque a expressão gênica reflete o status da atividade celular, ao passo que os dados histológicos refletem a execução de uma cascata de eventos sinalizados pela atividade gênica e expressos no tecido ao longo do tempo. Visto que existem diferentes mecanismos complexos que controlam a expressão gênica e proteica, a seguir foram discutidos os resultados obtidos no presente estudo.

Num primeiro momento foi realizada análise comparativa dos Grupos Experimentais (ERM, ERM+FC) em relação aos Grupos Controles (GC, FC). Em segunda análise, os valores de expressão gênica do grupo ERM foram comparados aos do grupo $E R M+F C$.

A expressão gênica de $B s p$, Onc e $O c c$ foi significativamente maior para o grupo submetido à expansão maxilar (ERM) comparado ao grupo controle (GC) nos tempos de 3 , 7 e 14 dias. Houve estímulo gênico para Bmp-2 aos 7, 14 e 21 dias do grupo ERM, enquanto que a expressão gênica de Opn apresentou aumento significante em todos os períodos de tempo avaliados para o grupo ERM. Estes resultados sugerem que, durante todo o período de reparo, há expressão de genes relacionados com o processo de formação óssea nos animais que não foram expostos à fumaça de cigarro. Os grupos de animais submetidos à exposição de fumaça $(F C)$ e expansão rápida da maxila associada com a fumaça de cigarro (ERM+FC) não apresentaram valores de expressão gênica estatisticamente significantes em relação aos do grupo controle, demonstrando que a fumaça de cigarro interfere negativamente na expressão desses genes.

Quando considerada a expressão gênica da tríade Rank/Rankl/Opg, houve aumento significativo para Rank e Rankl em todos os períodos avaliados do grupo ERM, enquanto que para Opg o aumento observado foi significante apenas aos 7, 14 e 21 dias quando comparados ao GC. No grupo ERM+FC também foi observada maior expressão gênica de Rank e Rankl, embora de menor magnitude, em todos os períodos avaliados para Rank e aos 3 e 14 dias para Rankl em comparação ao GC. Observa-se por meio destes dados que o estímulo gênico para reabsorção óssea ocorre durante todo o período de reparo e é mais expressivo no grupo de animais que não foi exposto à fumaça, enquanto que o estímulo gênico para evitar reabsorção óssea foi observado apenas no 
grupo ERM em períodos intermediários e tardios do processo de reparo, fatos também comprovados com os cortes histológicos, pois nos períodos de observação tardia (21 dias) houve um aumento no grau de deposição óssea, principalmente no grupo ERM.

Foi possível observar, ainda, estímulo gênico para Onc e Occ no grupo ERM quando comparado ao grupo ERM+FC nos tempos de 3, 7 e 14 dias, enquanto que para Bsp observou-se esse estímulo gênico nos tempos de 3 e 14 dias. A expressão gênica de Bmp-2 foi significativamente maior aos 14 e 21 dias no grupo ERM em relação a ERM+FC, ao passo que não foram observadas diferenças entre estes grupos para a expressão gênica de Opn. A sinalização gênica demonstrou ser maior para o processo de formação óssea no grupo de animais submetidos à expansão da maxila e que não foram expostos à inalação de fumaça de cigarro, fato confirmado com os achados histológicos e que pode ser caracterizado como uma formação óssea de reparo.

A comparação entre os grupos ERM e ERM+FC indicou maior expressão gênica de Rank em todos os períodos de tempo avaliados, maior expressão de Rankl aos 7 e 14 dias, e para Opg o estímulo gênico ocorreu aos 7, 14 e 21 dias nos animais que não foram expostos à fumaça de cigarro. Mais uma vez a fumaça de cigarro pareceu prejudicar a sinalização de genes relacionados ao processo de reabsorção óssea.

A ONC está envolvida na regulação do turnover da matriz, na migração e proliferação celular (Jandeleit-Dahm et al., 2000; Kos e Wilding, 2010), e devido a estas propriedades, esta proteína tem participação no processo de reparo, angiogênese e inflamação (Brekklen e Sage, 2001). Esses dados justificam o aumento na expressão gênica de Onc observado neste estudo para o grupo ERM, nos tempos de 3, 7 e 14 dias. Esta modulação na expressão deste gene é importante nas fases iniciais e intermediária de reparo pós-disjunção e não foi observada no grupo ERM+FC. A exposição à fumaça de cigarro parece prejudicar o processo de reparo quando se analisa a expressão desse gene, uma vez que os valores de expressão gênica para Onc no grupo ERM+FC são similares aos observados para os grupos GC e FC em todos os períodos avaliados.

Em estudo sobre avaliação da expressão gênica e proteica de ONC, integrina $\beta 5$ e colágeno durante a movimentação axial fisiológica de dentes de ratos, foi constatada uma maior regulação destes marcadores em dentes com movimento axial pós-irruptivo comparado ao grupo controle (Luan et al., 2007). Tais resultados suportam a presente pesquisa, que mostrou um maior estímulo de Onc aos 7 e 14 dias de avaliação no grupo ERM, apesar das diferenças entre o tipo de estímulo aplicado e o tipo de estudo utilizado.

A OCC é uma proteína não colágena da matriz de tecidos mineralizados, sintetizada pelos osteoblastos, odontoblastos e condrócitos hipertrofiados. O gene Occ é considerado um marcador da atividade e função dos osteoblastos, um marcador tardio de osteoblastos diferenciados ou maduros (Tanaka et al., 2007), marcador de formação óssea 
(Motyl et al., 2009), além de participar no processo de reabsorção óssea e mineralização (Roach, 1998). No presente trabalho houve modulação de osteocalcina na expressão gênica do grupo ERM de maneira semelhante à observada para a osteonectina. Foi observado um estímulo gênico de Occ no período de 3, 7 e 14 dias para o grupo ERM quando comparado ao GC. Mais uma vez a fumaça de cigarro parece prejudicar o processo de remodelação óssea, considerando-se que não houve alteração nos valores de expressão gênica para Occ no grupo ERM+FC. Os achados de Ramp e colaboradores (1988) confirmam este efeito prejudicial da fumaça na expressão deste gene em um estudo analisando o efeito da nicotina sobre as culturas de células do tipo osteoblasto. Os resultados mostraram que a nicotina inibiu a atividade da fosfatase alcalina e a síntese de colágeno num padrão dose-dependente, o que denota alteração no padrão normocelular destas células.

A BSP é mais uma proteína não colágena envolvida no processo de formação óssea e secretada por osteoblastos. A expressão do RNAm de Ibsp foi avaliada durante movimentação ortodôntica em roedores e observou-se uma intensa sinalização de sialoproteína óssea na área de tração nos osteoblastos da região de septo interradicular do molar submetido à movimentação. Contudo, aos 7 dias já não havia mais sinalização gênica (Domon et al., 2001). No presente estudo, pode-se observar que a ERM influenciou a modulação gênica de $I b s p$ nos períodos de 3, 7 e 14 dias, o que demonstra uma sinalização para o processo de formação óssea não só no período inicial, como também intermediário pós-disjunção. Esta diferença nos padrões de resposta pode ser justificada pela maior área de resposta tecidual envolvida neste estudo - toda a sutura palatina mediana - quando comparada à região interradicular de molar avaliada no outro trabalho, além do que as fibras da sutura demonstraram, histologicamente, estarem distendidas e em processo de reparo nos períodos tardios do experimento.

A BMP-2 é uma proteína importante no processo de desenvolvimento ósseo e cartilaginoso. Ela está envolvida com a diferenciação de células mesenquimais em osteoblastos e condroblastos, na via de sinalização do TGF- $\beta$ (fator de transformação do crescimento) e na interação de receptores de citocina (Chen et al., 2004). Os resultados do presente estudo demonstraram um aumento significativo na expressão gênica de Bmp-2 para o grupo ERM nos períodos de 7, 14 e 21 dias quando comparado ao GC. Esta sinalização expressiva pós-disjunção em períodos intermediários e tardios parece estar relacionada com o processo de maturação óssea. O efeito da força compressiva na expressão gênica e proteica de BMP foi estudada em cultura de células osteoblásticas humanas (Mitsui et al., 2005) e foi observada elevada expressão gênica e proteica de BMP de maneira tempo-dependente (1 a 24 horas). Ao contrário do nosso trabalho, em que a aplicação de forças de tração foi realizada in vivo, no estudo de Mitsui e 
colaboradores a força compressiva foi aplicada diretamente nos osteoblastos, o que pode explicar a resposta estimulatória imediata na expressão gênica de $B m p-2$, além disso nossa área de estudo foi de tração e não de compressão.

A inalação de fumaça de cigarro impediu o aumento da expressão gênica de Bmp2 no grupo $E R M+F C$, com diferença estatisticamente significante em relação ao grupo ERM nos períodos de 14 e 21 dias. Em experimento que avaliou a ação direta da fumaça de cigarro sobre as células osteoprogenitoras humanas, observou-se que a fumaça de cigarro inibiu a proliferação destas células em osteoblastos (Liu et al., 2001). É possível que a falta de estímulo gênico para $B m p-2$ observado no grupo de animais submetidos à disjunção maxilar e fumaça de cigarro esteja associada à inibição no processo de diferenciação dos osteoblastos.

Diversos estudos tem demonstrado que a OPN parece ter um papel importante na regulação da resposta celular em diferentes condições de estresse químico, físico e mecânico, além de ter papel crítico na remodelação óssea induzida (Denhart e Noda, 1998; Terai et al., 1999; Nomura et al., 2000). Sabe-se que o estresse mecânico deforma a matriz óssea e gera um estímulo que leva ao processo de remodelação óssea. A OPN que está presente na matriz óssea é requerida para participar neste processo, uma vez que é necessária para a função (Terai et al., 1999; Fujihara et al., 2006; Chung et al., 2008) e aumento da sobrevivência dos osteoclastos (Tanabe et al., 2011), além de também reduzir a diferenciação, proliferação e quimiotaxia de osteoblastos e osteoclastos (Terai et al., 1999, Ishima et al., 2001; Ishima et al., 2007). No presente estudo foi observada estimulação gênica de Opn no grupo ERM em todos os tempos avaliados, mostrando desta maneira que a osteopontina é regulada em condições de estresse mecânico. Embora sem significância estatística, observa-se que houve tendência a estímulo na expressão gênica de Opn em animais submetidos à ERM+FC, o que sugere que a fumaça de cigarro parece influenciar negativamente a atividade deste mediador em situação de reparo ósseo pósERM.

O estudo sobre a localização e a expressão de diversas proteínas osteogênicas também mostrou a presença de OPN na matriz óssea e na linha de reversão, sugerindo que esta proteína tivesse um papel durante o processo de reabsorção óssea (Roach, 1994). Estes dados corroboram com o trabalho que mostrou a expressão gênica de OPN no processo de remodelação durante a movimentação dental fisiológica e a expressão de RNAm nas células da superfície de reabsorção (Takano-Yamamoto et al., 1994). No presente estudo parece que a osteopontina está envolvida com o processo de remodelação óssea, com atividade osteoblástica e osteoclástica dinâmica e intensa pós-disjunção, aparentemente suscetível a um complexo sistema de controle gênico.

Alguns autores avaliaram a expressão de genes osteogênicos durante a 
estimulação mecânica contínua em células mesenquimais e progenitoras humanas em culturas osteogênicas diferenciadas e indiferenciadas aos 7 e 14 dias de estudo. Neste estudo observaram que a estimulação mecânica aumentou a expressão de genes osteogênicos como colágeno, Onc, Opn, Bmp-2 e Occ aos 7 e 14 dias. Além disso, a estimulação mecânica mostrou um aumento significante de cálcio depositado e de atividade de fosfatase alcalina (ALP) no grupo de células diferenciadas com estímulo mecânico aos 7 e 14 dias. Estes autores concluíram que o estímulo mecânico induziu o aumento da expressão de marcadores osteogênicos precoces e tardios em células diferenciadas osteogênicas (Lohberger et al., 2014). Tais achados confirmam os resultados encontrados nesta pesquisa. O estímulo de disjunção aplicado em sutura palatina mediana de ratos resultou em aumento na expressão de todos esses genes osteogênicos em períodos precoces e tardios do processo de reparo ósseo.

A influência negativa da fumaça de cigarro na sinalização gênica dos diversos mediadores que modulam a formação óssea foi bastante consistente neste estudo, e vai de encontro a dados prévios em que se observou que a fumaça de cigarro inibiu a proliferação de células osteoprogenitoras humanas em células tipo osteoblasto (Liu et al., 2001). Boa parte da influência negativa da fumaça de cigarro sobre o reparo ósseo tem sido atribuída à nicotina, substância altamente citotóxica e que está presente em maior quantidade na fumaça resultante da queima do cigarro (Giorgetti et al., 2012; Santiago et al., 2017). Diversos estudos in vitro e in vivo demonstraram o efeito inibitório da nicotina na diferenciação dos osteoblastos (Ramp et al., 1988; Pinto et al., 2002; Henemyre et al., 2003, Tanaka et al., 2007; Zhou et al., 2013; Shintcovsk et al., 2014). A avaliação in vitro do efeito de altas doses de nicotina sobre a atividade de células precursoras de medula óssea humana culminou em redução na expressão gênica de Bmp-2 e Ocn, o que denota prejuízo no processo de proliferação e diferenciação osteogênica (Shen et al., 2013). Da mesma forma, a administração de altas doses de nicotina em cultura de células do tipo osteoblasto de coelho demonstrou efeito inibitório na expressão gênica de Bmp-2, assim como em outros mediadores osteogênicos e angiogênicos, reforçando o papel nocivo da nicotina sobre a atividade osteoblástica ( $\mathrm{Ma}$ et al., 2011). Em células humanas do ligamento periodontal, o tratamento com nicotina também levou à redução da expressão gênica de alguns marcadores de diferenciação osteoblástica como fosfatase alcalina, osteopontina e osteocalcina (Lee et al., 2009).

A exposição de osteoblastos humanos a concentrações sub-tóxicas de nicotina, no entanto, resultou em aumento na expressão do gene para Onc, bem como em superexpressão de genes envolvidos com a maturação e diferenciação de osteoblastos, como fosfatase alcalina, Runx-2 e Bsp (Marinucci et al., 2014). A variação de resultados pode ser explicada pela diferença na metodologia empregada, uma vez que estudos in vitro não 
estão sujeitos a regulações complexas do organismo no qual tais células estão atuando. Além disso, esse estudo prévio fez uso de exposição à nicotina em cultura de células, enquanto que no presente estudo a exposição à nicotina foi realizada por meio da inalação de fumaça de cigarro, caracterizando o efeito passivo da fumaça de cigarro.

O receptor ativador do Fator Nuclear Kappa B (RANK), o ligante de RANK (RANKL) e a osteoprotegerina (OPG) fornecem a base celular e molecular para o crosstalk entre osteoblasto e osteoclasto, células cruciais no processo de remodelação óssea (Horowitz et al., 2001). O RANK, que pertence à superfamília do fator de necrose tumoral (TNF), está presente na superfície dos precursores de osteoclastos e é ativado pelo RANKL. Esta interação induz a diferenciação de monócitos em osteoclastos, assim iniciando o processo de reabsorção. O sistema RANK/RANKL/OPG controlam o processo de remodelação e fazem parte do metabolismo ósseo. O RANKL é um agonista que regula aspectos importantes dos osteoclastos como diferenciação, fusão, sobrevivência, ativação e apoptose. Uma vez que ativação de RANK por RANKL inicia o processo de reabsorção óssea, este mediador solúvel pode ser considerado um marcador de reabsorção óssea. Por outro lado, a OPG, também membro da superfamília do TNF, é um receptor solúvel secretado, que é um antagonista do RANKL, uma vez que interrompe esta ativação pela ligação direta ao RANKL evitando o processo de reabsorção óssea, isto é, a OPG regula negativamente o processo de osteoclastogênese (Horowitz et al., 2001).

No presente estudo, observamos nos grupos ERM e ERM+FC um estímulo gênico de Rank em todos os períodos de tempo avaliados, em relação ao GC. A comparação entre os grupos ERM e ERM+FC indicou maiores níveis de expressão gênica de Rank em todos os períodos avaliados para o grupo de animais que não foi exposto à fumaça de cigarro. Além disso, no grupo ERM+FC foi observada inibição gênica de Rankl aos 7 e 14 dias comparado ao grupo ERM. Quando comparados ao GC, todos os períodos de ERM indicaram estímulo gênico de Rankl, enquanto que apenas os períodos de 3 e 14 dias de $\mathrm{ERM}+\mathrm{FC}$ indicaram um estímulo de menor magnitude. Para a osteoprotegerina no grupo ERM, houve estímulo gênico aos 7, 14 e 21 dias em relação ao GC e ao grupo ERM+FC. Estes resultados nos levam a acreditar que em todos os períodos avaliados há um estímulo gênico para promover a reabsorção óssea nos grupos de animais submetidos à ERM, e que esse estímulo gênico foi prejudicado nos grupos que também foram submetidos à inalação de fumaça - ERM+FC. Ainda, é possível supor que estímulo gênico para evitar a reabsorção óssea só acontece em períodos mais tardios e apenas nos animais que foram submetidos à ERM, mas não à inalação de fumaça.

O aumento de Rank, Rankl e Opg observado no grupo ERM coincide com dados encontrados na literatura. Arnez e colaboradores (2017) avaliaram a sinalização osteoclastogênica em região de sutura palatina de ratos após realização de ERM. 
Constataram que houve aumento na expressão de Rank e Rankl durante o período inicial de reparo ósseo e aumento de Opg nos períodos intermediários do reparo. A ERM é rotineiramente utilizada para o tratamento de constrição maxilar e este procedimento induz um estresse mecânico capaz de promover remodelação óssea na região de sutura palatina. Considerando-se que a remodelação de osso alveolar consiste na interação entre reabsorção óssea promovida por osteoclastos e formação óssea induzida por osteoblastos, é bastante razoável atribuir as variações de expressão gênica de Rank/Rankl/Opg ao trauma resultante da ERM. A relação gênica de Rankl e Opg (razão Rankl/Opg) tem o intuito de mostrar se o metabolismo ósseo estava mais direcionado para a formação ou reabsorção óssea. Os dados do presente estudo demonstraram um aumento na razão Rankl/Opg nos períodos iniciais de reparo para o grupo ERM quando comparado ao GC, o que pode sinalizar o predomínio de atividade osteoclástica nesta fase precoce de reparo e inflamação. De fato, a avaliação histológica constatou a existência de numerosos osteoclastos no interior das lacunas de Howship, dentro das cavidades medulares, o que caracterizava uma intensa reabsorção óssea solapante no grupo ERM aos 7 dias. Observou-se também a presença de células inflamatórias - neutrófilos (polimorfornucleares) e mononucleares, compatível com a situação de trauma gerada pela ERM, e que irá colaborar para o início do processo de deposição óssea por meio do recrutamento de diversos fatores de crescimento e citocinas. Conforme descrito na literatura, a movimentação ortodôntica promove sítios de inflamação ao redor do ponto de aplicação da força, com consequente infiltrado de fatores de crescimento e citocinas, como Tnf e interleucina-1, que são mediadores inflamatórios importantes envolvidos no reparo ósseo e na ativação de genes envolvidos no processo de remodelação óssea (Garlet et al., 2007).

A movimentação dentária em ratos resultou em aumento da expressão de Rankl no tecido periodontal (Nakano et al., 2011). Em outro estudo, foi demonstrado que células do ligamento periodontal podem regular a osteoclastogênese por meio de atividade estimulatória via Rankl e inibitória via Opg (Kanzaki et al., 2001). Tais resultados suportam os achados da presente pesquisa, visto que a expressão de Rankl foi estimulada em áreas da sutura palatina de ratos submetidas à tensão pelo procedimento de ERM. Em consequência, houve provável aumento da atividade osteoclástica que resultou em remodelação óssea e alterações na microarquitetura observadas histologicamente na sutura palatina nos primeiros dias pós-ERM. O aumento na expressão de Opg ocorrido em períodos intermediários e tardios de reparo parece estar relacionado com a redução de atividade osteoclástica, o que denota um papel importante deste mediador no processo de formação óssea. De fato, a avaliação histológica indicou que as células da superfície óssea sutural eram volumosas em vários pontos indicando atividade de síntese no grupo de 
animais 21 dias pós-disjunção. O espaço sutural foi preenchido com tecido ósseo neoformado de tal forma que assemelhou-se ao grupo controle, e o tecido sutural estava bastante celularizado em toda a sua extensão.

Com relação ao efeito da exposição à fumaça de cigarro, a avaliação da expressão gênica de mediadores relacionados à reabsorção óssea em células do ligamento periodontal humano tratadas com nicotina demonstrou redução na expressão de Opg e aumento na expressão de Rankl, o que sugere estímulo para o processo de reabsorção óssea no padrão de atividade destas células (Lee et al., 2009). Da mesma forma, células de ligamento periodontal de 3 pacientes submetidos a extração de 1ำ prémolar foram coletadas e cultivadas em meio de cultura, com acréscimo de nicotina por 72 horas (Li-Zheng et al., 2013). Por meio de metodologia de PCR real-time, este estudo constatou maiores níveis de expressão gênica para Rankl após exposição destas células à nicotina, enquanto que houve inibição da expressão de Opg, resultando numa razão Rankl/Opg direcionada para a reabsorção óssea. Esses achados da literatura concordam em parte com o presente estudo, pois houve efeito inibitório na expressão de Opg no grupo de animais submetido à ERM+FC. Porém, nestes mesmos animais, não foi observado aumento na expressão de Rankl em consequência da exposição à fumaça de cigarro. Houve aumento de Rankl no grupo ERM+FC quando comparado ao grupo controle em virtude do trauma da disjunção. A comparação do grupo ERM com o grupo ERM+FC demonstrou que a exposição à fumaça de cigarro inibiu a expressão de Rankl. Considerando-se que o presente estudo foi realizado in vivo, é provável que a modulação da atividade desses genes esteja submetida a um complexo sistema regulador, enquanto que avaliações in vitro caracterizam respostas de células isoladas, que não estão sob a influência de outros fatores regulatórios inerentes a um organismo em funcionamento. Além disso, a expressão gênica celular nesses estudos in vitro foi avaliada com relação ao efeito da nicotina, que é o componente majoritário da fumaça de cigarro, mas não exclusivo. No presente trabalho, os animais foram expostos à fumaça de cigarro e todas as substâncias nocivas que a constituem, o que poderia justificar a diferença de resposta na expressão gênica observada.

A exposição de células humanas precursoras osteoclásticas a diferentes concentrações de nicotina evidenciou um aumento no número de osteoclastos mononucleados e redução na quantidade de osteoclastos multinucleados, além de inibição na expressão gênica de alguns mediadores de atividade osteoclástica (Tanaka et al., 2013). Estes dados estão de acordo com os achados histológicos do presente estudo. Enquanto nos períodos iniciais de reparo ósseo podia-se observar grande proliferação vascular e numerosos osteoclastos presentes no interior das lacunas de Howship, caracterizando uma intensa reabsorção óssea solapante no grupo ERM, no grupo 
$\mathrm{ERM}+\mathrm{FC}$ o tecido sutural remanescente estava alterado, apresentando células contraídas, com núcleos irregulares e picnóticos, bem como as trabéculas ósseas nesta região exibiram lacunas vazias. Em períodos tardios de reparo, o espaço sutural foi preenchido com tecido ósseo neo-formado no grupo ERM, de tal forma que assemelhou-se ao grupo controle, e o tecido sutural estava bastante celularizado em toda a sua extensão. Entretanto, no grupo ERM+FC o espaço sutural ainda não apresentava uma largura uniforme em sua extensão, e algumas áreas de remodelação óssea com osteoclastos em lacunas de Howship caracterizavam que o processo de reabsorção óssea frontal ainda ocorria. De uma maneira geral, durante todo o período de reparo as características histológicas mostraram-se atrasadas no grupo ERM+FC em relação ao grupo de animais submetidos apenas ao procedimento de disjunção, o que demonstra o efeito prejudicial da fumaça de cigarro ao processo de reparo ósseo em região de sutura palatina de ratos.

Em estudo histométrico realizado por Giorgetti e colaboradores (2012), avaliou-se a influência da exposição de ratos à inalação de fumaça de cigarro sobre o reparo ósseo após a exodontia dos $2^{\text {os }}$ molares inferiores em diversos períodos experimentais. Aos 7 dias, a fumaça de cigarro influenciou negativamente o preenchimento ósseo mostrando diferença estatisticamente significante para os parâmetros histométricos tecido não mineralizado e defeito remanescente. Dessa forma, concluíram que a inalação de fumaça de cigarro pode afetar o reparo ósseo alveolar inicial, o que pode ser crítico para a quantidade e qualidade da nova formação óssea em fumantes. Em nosso modelo experimental, o reparo ósseo foi avaliado por meio do procedimento de ERM e, de acordo com as observações histológicas, não só os períodos iniciais de reparo foram prejudicados pela ação da fumaça de cigarro como também os mais tardios, em que foi possível observar formação de osso mais lenta e desorganizada. A exposição prévia dos animais à inalação de fumaça de cigarro por 21 dias realizada em nosso estudo caracteriza exposição crônica aos efeitos nocivos dos agentes constituintes da fumaça de cigarro, enquanto que o período de exposição prévia de 3 dias realizada no outro estudo é mais compatível com efeito agudo desses agentes sobre o processo de reparo ósseo avaliado em cada estudo. Tal fato pode explicar os efeitos negativos que a inalação da fumaça de cigarro provoca desde o início até períodos mais tardios do reparo ósseo em nosso estudo.

A administração sistêmica de nicotina por meio de injeções intraperitoniais durante 3 dias consecutivos em camundongos acelerou a destruição de osso alveolar após indução de periodontite (Kubota et al., 2016). Em níveis moleculares, esses autores detectaram aumento na expressão gênica de Rankl 7 dias após a indução de periodontite nos linfonodos submandibulares dos camundongos submetidos às injeções de nicotina. Em nosso estudo foi observado efeito contrário da nicotina, tendo em vista que o grupo de 
animais submetidos ao procedimento de disjunção e expostos à fumaça de cigarro apresentou menores valores de expressão de Rankl comparado aos animais submetidos apenas à disjunção, embora tais níveis tenham sido maiores em relação aos do grupo controle. Considerando-se que o quadro de periodontite caracteriza-se pela ação bacteriana associada à destruição periodontal, é possível que a atividade das bactérias envolvidas nessa patologia tenha colaborado para a maior extensão de reabsorção óssea e, sendo assim, ao aumento da expressão gênica de Rankl observado. Além disso, o modelo de injeções intraperitoniais de nicotina certamente deve desencadear vias de resposta diferente daquelas observadas em nosso modelo experimental, em que os animais foram expostos à inalação de fumaça de cigarro.

O efeito prejudicial da nicotina sobre a perda óssea em modelos de inflamação periodontal induzidas já está bem estabelecido na literatura (Nociti et al., 2000; Chang et al., 2003; Laxman e Annaji, 2008; Liu et al., 2010). Em virtude da escassez de trabalhos que relacionem movimentação dentária neste tipo de modelo, Kirschneck e colaboradores (2015) avaliaram o efeito da aplicação de forças ortodônticas sobre a perda óssea periodontal induzida pela nicotina. A análise in vivo demonstrou que a aplicação de forças para mesializar o molar superior esquerdo de ratos resultou em aumento da síntese de enzimas inflamatórias, além de proteínas e citocinas envolvidas com o processo de reparo tecidual no ligamento periodontal. A associação de força ortodôntica à injeções subcutâneas diárias de nicotina resultou em aumento mais significativo de enzimas inflamatórias e citocinas, bem como em aumento na razão Rankl/Opg e consequente estímulo da diferenciação osteoclástica. Os autores observaram uma resposta periodontal exacerbada nos grupos em que houve movimentação dentária e exposição à nicotina, com maior perda de osso alveolar após aplicação da força ortodôntica. Extrapolando para a prática clínica, sugeriram que o ortodontista deve estar ciente que pacientes fumantes apresentam maior potencial de perda óssea periodontal durante 0 tratamento, e recomendaram que o hábito de fumar seja interrompido uma vez que se inicie a movimentação ortodôntica. Em nosso estudo, o estímulo de força aplicada foi de tração, e não de compressão, ainda assim foi observado aumento na razão de Rankl/Opg nos períodos inicias de reparo em animais expostos à fumaça de cigarro. Esse aumento encontrado na expressão gênica refletiu na avaliação histológica, em que se observou resposta inflamatória exacerbada em fase precoce de reparo, seguida por processo de reparo mais lento sob a ação da nicotina, com presença de atividade osteoclástica detectada até períodos mais tardios estudados. 
A exposição à fumaça de cigarro causou prejuízo consistente na expressão gênica da maioria dos mediadores ósseos avaliados neste estudo, além do reparo mais lento e desorganizado observados histologicamente. No entanto, futuras investigações são necessárias para elucidar os mecanismos moleculares pelos quais a fumaça de cigarro atua no organismo, bem como as vias de sinalização envolvidas no processo de remodelação óssea sob tais circunstâncias. 



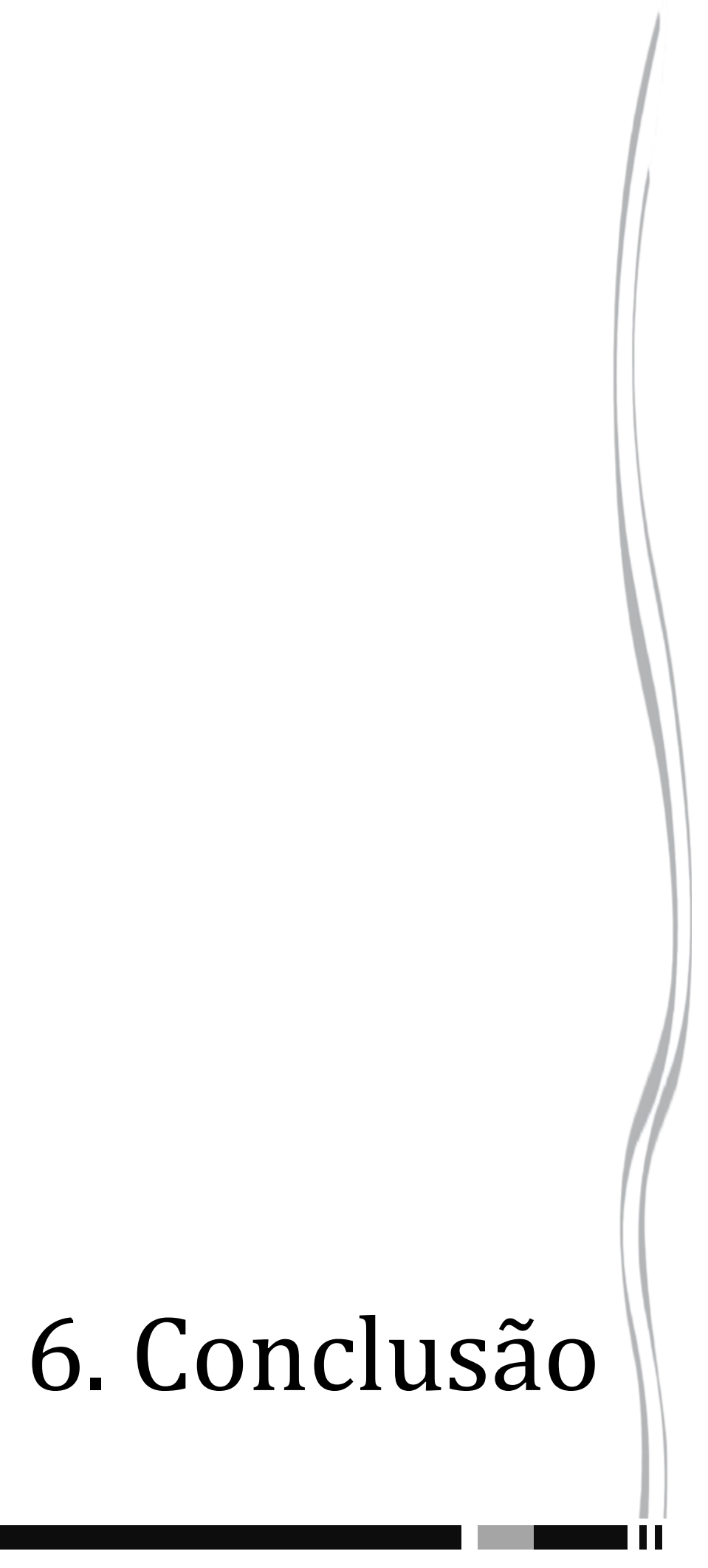





\section{CONCLUSÃO}

A partir do presente estudo pode-se concluir que:

1. Houve estímulo à osteoclastogênese nos grupos submetidos à ERM, com menor magnitude naquele que também foi exposto à fumaça de cigarro. Os marcadores de osteogênese foram estimulados nos animais submetidos à ERM, durante todos os períodos avaliados. A associação entre os dois fatores de estudo, fumaça de cigarro e expansão rápida da maxila, pareceu ter contribuído para o atraso no reparo ósseo.

2. A ERM resultou em intensa remodelação óssea na sutura palatina, caracterizada por tecido desorganizado com intensas áreas inflamatórias, hemorrágicas e reabsortivas em períodos iniciais, seguida por tecido ósseo neo-formado bastante celularizado com numerosos vasos sanguíneos, fibroblastos e osteoblastos em fase tardia de reparo. A inalação de fumaça de cigarro exacerbou e prolongou os eventos inflamatórios após ERM, com presença de tecido desorganizado e atividade osteoclástica persistente em períodos mais tardios do reparo.

Assim, os achados histológicos somados à investigação molecular das vias de sinalização osteogênicas mostraram que a exposição à fumaça de cigarro prejudicou o processo de reparo ósseo após a ERM nos diferentes tempos analisados, tornando-o mais lento e desorganizado. 

Referências 



\section{REFERÊNCIAS}

Alberts B, Johnson A, Lewis J, Raff M, Roberts K, Walter P. Molecular biology of the cell. $5^{\mathrm{a}}$ ed. Nova York: Garland Science, 2008.

Amorim FPLG, Ornellas SS, Diniz SF, Batista AC, Silva TA. Imbalance of RANK, RANKL and OPG expression during tibial fracture repair in diabetics rats. $J \mathrm{Mol}$ Hist. 2008; 39(4):401-8.

Arnez MFM, Ribeiro LSN, Barretto GD, Monteiro PM, Ervolino E, Stuani MBS. RANK/RANKL/OPG expression in rapid maxillary expansion. Br Dent J. 2017; 28(3):296-300.

Boyle WJ, Simonet WS, Lacey DL. Osteoclast differentiation and activation. Nature 2003; 15:337-42.

Brekken RA, Sage EH. SPARC, a matricellular protein: at the crossroads of cellmatrix communication. Matrix Biol. 2001; 19:816-27.

Butz AM, Breysse P, Rand C, Curtin-Brosnan J, Eggleston P, Diette GB, Williams D, Bernert JT, Matsui EC. Household smoking behavior: effects on indoor air quality and health of urban children with asthma. Matern Child Health J. 2011; 15(4):460-8.

Camozzi V, Tossi A, Simoni E, Pagani F, Francucci CM, Moro L. Role of biochemical markers of bone remodeling in clinical practice. J Endocrinol Invest. 2007; 30(6):13-7.

Carvalho RS, Schaffer JL, Gerstenfeld LC. Osteoblasts induce osteopontin expression in response to attachment on fibronectin: demonstration of a common role for integrin receptors in the signal transduction processes of cell attachment and mechanical stimulation. J Cell Biochem. 1998; 70:376-90.

Carvalho AC, Paiva SM, Viegas CM, Scarpelli AC, Ferreira FM, Pordeus IA. Impact of malocclusion on oral health-related quality of life among Brazilian preschool children: a population-based study. Braz Dent J. 2013; 24:655-61.

Cattaneo V, Celta G, Rota C, Vezzoni F, Gallanti A. Volatile components of cigarette smoke: effect of acrolein and acetaldehyde on human gingival fibroblasts in vitro. $J$ Periodontol. 2000; 71(3):425-32.

Chang Y, Tsai C, Yang $S$ et al. Induction of cyclooxygenase-2 mRNA and protein expression in human gingival fibroblasts stimulated with nicotine. J Periodontal Res. 2003; 38:496-501.

Chen D, Zhao M, Mundy GR. Bone morphogenetic proteins. Growth Factors. 2004; 22(4):233-41.

Chung JW, Kim MS, Piao ZH, Jeong M, Yoon SR, Shin N, Kim SY, Hwang ES, Yang Y, Lee SH, Kim YS, Choi I. Osteopontin promotes the development of natural killer cells from hematopoietic stem cells. Stem cells. 2008; 26:2114-23.

Collett AR, Mather JC, Phillips M. Smoking patterns in adolescent orthodontic patients and school children. Aust Orthod J. 1999; 15(5):276-83. 
Cox G, Einhorn TA, Tzioupis C, Giannoudis PV. Bone turnover markers in fracture healing. J Bone Joint Surg Br. 2010; 92-B:329-34.

Denhardt DT, Noda M. Osteopontin expression and function: role in bone remodeling. J Cell Biochem. 1998; (30-31):92-102.

Dodds RA, Connor JR, James IE, Rykaczewski EL, Appelbaum E, Dul E, Gowen M. Human osteoclasts, not osteoblasts, deposit osteopontin onto resorption surfaces: an in vitro and ex vivo study of remodeling bone. J Bone Miner Res. 1995; 10:1666-80.

Doll R, Peto R, Boreham J, Sutherland I. Mortality in relation to smoking: 50 years observations on male British doctors. Br Med J. 2004; 328:1519.

Domon S, Shimokawa H, Yamaguchi S, Soma K. Temporal and spatial mRNA expression of bone sialoprotein and type I collagen during rodent tooth movement. Eur J Orthod. 2001; 23:339-48.

Elias LS, Costa RF, Carvalho MA, Batista AC, Silva TA, Leles CR, Mendonça EF. Markers of bone remodeling in neoplastic and bone-related lesions. Oral Surg Oral Med Patol Oral Rad Endo. 2010; 110(5):624-31.

Ehrlich PJ, Lanyon LE. Mechanical strain and bone cell function: a review. Osteoporos Int. 2002; 13:688-700.

Fujihara S, Yokozeki M, Oba Y, Higashibata Y, Nomura S, Moriyama K. Function and regulation of osteopontin in response to mechanical stress. J Bone Mineral Res. 2006; 21:956-64.

Garlet TP, Coelho U, Silva JS, Garlet GP. Cytokine expression pattern in compression and tension sides of the periodontal ligament during orthodontic tooth movement in humans. Eur J Oral Sci. 2007; 115:355-362.

Giorgetti APO, César Neto JB, Casati MZ, Sallum EA, Nociti Junior FH. Cigarette smoke inhalation influences bone healing of post-extraction tooth socket: a histometric study in rats. Braz Dent J. 2012; 23(3):228-34.

Grossi SG, Skrepcinski FB, DeCaro T, Zambon JJ, Cummins D, Genco RJ. Response to periodontal therapy in diabetics and smokers. J Periodontol. 1996; 67(10):1094-102.

Han XL, Meng Y, Kang N, Lv T, Bai D. Expression of osteocalcin during surgically assisted rapid orthodontic tooth movement in beagle dogs. J Maxillofac Surg. 2008; 66(12):2467-75.

Haverstoch BD, Mandracchia VJ. Cigarrete smoking and bone healing: implications in foot and ankle surgery. J Foot Ankle Surg. 1998; 37(1):69-74.

Henemyre CL, Scales DK, Hokett SD, Cuenin MF, Peacock ME, Parker MH et al. Nicotine stimulates osteoclast resorption in a porcine marrow cellmodel. $J$ Periodontol. 2003; 74(10):1440-6. 
Horowitz MC, Xi Y, Wilson K, Kacena MA. Control of osteoclastogenesis and bone resorption by members of the TNF family of receptors and ligands. Cytokine Growth Factor Rev. 2001; 12:9-18.

Hughes FJ, Turner W, Belibasakis G, Martuscelli G. Effects of growth factors and cytokines on osteoblast differentiation. Peridontol. 2000; 41:48-72.

Ishijima M, Rittling SR, Yamashita T, Tsuji K, Kurosawa $H$, Nifuji A, et al. Enhancement of osteoclastic bone resorption and suppression of osteoblastic bone formation in response to reduced mechanical stress do not occur in the absence of osteopontin. J Exp Med. 2001; 193:399-404.

Ishijima M, Tsuji K, Rittling SR, Yamashita T, Kurosawa H, Denhardt DT, et al. Osteopontin is required for mechanical stress-dependent signals to bone marrow cells. J Endocrinol. 2007; 193:235-43.

Ivanovski S, Li H, Haase HR, Bartold PM. Expression of bone associated macromolecules by gingival and periodontal ligament fibroblasts. J Periodont Res. $2001 ; 36: 131-41$.

Jandeleit-Dahm K, Rumble J, Cox AJ, Kelly DJ, Dziadek M, Cooper ME, Gilbert RE. SPARC gene expression is increased in diabetes-related mesenteric vascular hypertrophy. Microvasc Res. 2000; 59(1):61-71.

Kos K, Wilding JP. SPARC: a key player in the pathologies associated with obesity and diabetes. Nat Rev Endocrinol. 2010; 6:225-35.

Kaku M, Uoshima K, Yamashita Y, Miura H. Investigation of periodontal ligament reaction upon excessive occlusal load - osteopontin induction among periodontal ligament cells. J Periodontal Res. 2005; 40:59-66.

Kanzaki H, Chiba M, Shimizu Y, Mitani H. Dual regulation of osteoclast differentiation by periodontal ligament cells through RANKL stimulation and OPG inhibition. J Dent Res. 2001; 80:887-91.

Kirkanydes S, O'banion MK, Subtelny JD. Nonsteroidal anti-inflammatory drugs in orthodontic tooth movement: Metalloproteinase activity and collagen synthesis by endothelial cells. Am J Orthod Dentofac Orthop. 2000; 118:203-9.

Kirschneck C, Proff P, Maurer M, Reicheneder C, Römer P. Orthodontic forces add to nicotine-induced loss of periodontal bone. An in vivo and in vitro study. J Orofac Orthop. 2015; 76:195-212.

Klaassen CD. Agentes tóxicos ambientais não-metálicos. Poluentes atmosféricos, solventes e vapores pesticidas. In: Goodman \&Gilman, As Bases Farmacológicas da Terapêutica. 9 Ed. Rio de Janeiro: Mcgraw - Hill Interamericana; 1240-1257, 1996.

Klein-nulend J, Roelofsen J, Semeins CM, Bronckers AL, Burger EH. Mechanical simulation of osteopontin mRNA expression and synthesis in bone cell cultures. $J$ Cell Physiol. 1997; 170:174-81. 
Krishnan V, Davidovitch Z. Cellular, molecular, and tissue level reactions to orthodontic force. Am J Orthod Dentofacial Orthop. 2006; 129:1-32.

Kubota M, Yanagita M, Mori K, Hasegawa S, Yamashita M, Yamada S, Kitamura M, Murakami S. The effects of cigarette smoke condensate and nicotine on periodontal tissue in a periodontitis model mouse. PLoS one. 2016; 11(5):e0155594.

Kumar P, Londhe SM, Kotwal A, Mitra R. Prevalence of malocclusion and orthodontic treatment need in schoolchildren - An epidemiological study. Med J Armed Forces India. 2013; 69(4):369-74.

Laxman VK, Annaji S. Tobacco use and its effects on the periodontium and periodontal therapy. J Contemp Dent Pract. 2008; 9:97-107.

Le Mesurier SM, Stewart BW, Lykke AW. Injury to type-2 pneumocytes in rats exposed to cigarette smoke. Environ Res. 1981;24(1):207-17.

Lee HJ, Pi SH, Kim Y, Kim HS, Kim SJ, Kim YS, Lee SK, Kim EC. Effects of nicotine on antioxidant defense enzymes and RANKL expression in human periodontal ligament cells. J Periodontol. 2009; 80(8):1281-8.

Liu XD, Zhu YK, Umino T, Spurzem JR, Romberger DJ, Wang H. Cigarette smoke inhibits osteogenic differentiation and proliferation of human osteoprogenitor cells in monolayer and three-dimensional collagen gel culture. J Lab Clin Med. 2001; 137(3):208-19.

Liu $\mathrm{Y}$, Wu L, Wang $\mathrm{J}$ et al. Micro-computerized tomography analysis of alveolar bone loss in ligature- and nicotine-induced experimental periodontitis in rats. J Periodontal Res. 2010; 45:714-719.

Livak KJ, Schmittgen TD. Analysis of relative gene expression data using real-time quantitative and the 2 (-Delta Delta C(T)) method. Methods. 2001; 25(4):402-8.

Li-Zheng W, Duo-Mo D, Ying-Feng L, Xin G, Zhi-Fei Z, Xiao-Jing W. Nicotine favors osteoclastogenesis in human periodontal ligament cells co-cultured with CD4+T cells by upregulating IL-1ß. Int J Molec Med. 2013; 31:938-42.

Lohberger B, Kaltenegger H, Stuendl N, Payer M, Rinner B, Leithner A. Effect of cyclic mechanical stimulation on the expression of osteogenesis genes in human intraoral mesenchymal stromal and progenitor cells. Biomed Res Int. 2014; 2014:110.

Luan X, Ito Y, Holliday S, Walker C, Daniel J, Galang TM, Fukui T, Yamane A, Begole E, Evans C, Diekwisch TG. Extracellular matrix-mediated tissue remodeling following axial movement of teeth. J Histochem Cytochem. 2007; 55:127-40.

Ma L, Zwahlen RA, Zheng LW, Sham MH. Influence of nicotine on the biological activity of rabbit osteoblasts. Clin Oral Implants Res. 2011; 22(3):338-42.

Marinucci L, Bodo M, Balloni S, Locci P, Baroni T. Sub-toxic nicotine concentrations affect extracellular matrix and growth factor signaling gene expressions in human osteoblasts. J Cell Physiol. 2014; 229(12):2038-48 
Masella RS, Meister M. Current concepts in the biology of orthodontic tooth movement. Am J Orthod Dentofacial Orthop. 2006; 129:458-68.

Meikle MC. The tissue, cellular, and molecular regulation of orthodontic tooth movement: 100 years after Carl Sandstedt. Eur J Orthod. 2006; 28:221-40.

Merry K, Dodds R, Littlewood A, Gowen M. Expression of osteopontin mRNA by osteoclasts and osteoblasts in modeling adult human bone. J Cell Sci. 1993; 104:1013-20.

Ministério da Saúde. Secretaria de Assistência à Saúde. Instituto Nacional de Câncer - INCA. Estimativas da Incidência e Mortalidade por Câncer. Rio de Janeiro: INCA, 2002.

Miles RR. Turner CH, Santerre R, Tu Y, Mcclelland P, Argot J, Dehoff BS, Mundy CW, Rosteck PRJr, Bidwell J, Sluka JP, Hock J, Onyia JE. Analysis of differential gene expression in rat tibia after an osteogenic stimulus in vivo: mechanical loading regulates osteopontin and myeloperoxidase. J Cell Biochem. 1998; 68:355-65.

Morinobu M, Ishijima M, Rittling SR, Tsuji K, Yamamoto H, Nifuji A, Denhardt DT, Noda M. Osteopontin expression in osteoblasts and osteocytes during bone formation under mechanical stress in the calvarial suture in vivo. $J$ Bone Miner Res. 2003; 18:1706-15.

Mosely LH, Finseth F. Cigarette smoking: impairment of digital blood flow and wound healing in the hand. Hand. 1977; 9(2):97-101.

Motyl KJ, Botolin S, IrwinR, et al. Bone inflammation and altered gene expression. With type I diabetes early onset. J Cell Physiol. 2009; 218:575-83.

Moyers RE. Ortodontia. 4 ed. Rio de Janeiro: Guanabara Koogan; 1991. 483p.

Nakagawa M, Kukita T, Nakasima A, Kurisu K. Expression of the type I collagen gene in rat periodontal ligament during tooth movement as revealed by in situ hybridization. Arch. Oral Biol. 1994; 39:289-94.

Nakano Y, Yamaguchi M, Fujita S, Asano M, Saito K, Kasai K. Expressions of RANKL/RANK and M-CSF/c-fms in root resorption lacunae in rat molar by heavy orthodontic force. Eur J Orthod. 2011; 33:335-43.

Nociti FH Jr, Nogueira-Filho GR, Primo MT et al. The influence of nicotine on the bone loss rate in ligature-induced periodontitis. A histometric study in rats. $J$ Periodontol. 2000; 71:1460-4.

Nociti FH Jr, César NJ, Carvalho MD, Sallum EA. Bone density around titanium implants may be influenced by intermittent cigarette smoke inhalation - A histometric study in rats. Int J Oral Max Impl. 2002; 17(3):347-52.

Nomura S, Takano-Yamamoto T. Molecular events caused by mechanical stress in bone. Matrix Biol. 2000; 19:91-6. 
Öberg M, Jaakkola MS, Woodward A, Peruga A, Prüss-ustün A. Worldwide burden of disease from exposure to second-hand smoke: A retrospective analysis of data from 192 countries. Lancet. 2011; 377(9760):139-46.

Ong SC, Khanbay BS, McDonald JP et al. The novel use of three-dimensional surface models to quantify end visualized the immediate changes of the mid-facial skeleton following rapid maxillary expansion. Surgeon. 2013; 13:1-7.

Pinto JR, Bosco AF, Okamoto T, Guerra JD, Piza IG. Effects of nicotine on the healing of extraction sockets in rats. A histological study. Br Dent J. 2002; 13(1):3-9.

Ramp WK, Lenz LG, Galvin RJ. Nicotine inhibits collagen synthesis and alkaline phosphatase activity, but simulates DNA synthesis in osteoblast-like cells. Proc Soc Exp Biol Med. 1988; 197(1):36 -43.

Reddy ER, Manjula M, Sreelakshmi N, Rani ST, Aduri R, Patil BD. Prevalence of malocclusion among 6 to 10 year old Nalgonda School Children. J Int Oral Health. 2013; 5:49-54.

Roach HI. Why does bone matrix contain non-collagenous proteins? The possible roles of osteocalcin, osteonectin, osteopontin and bone sialoprotein in boné mineralisation and resorption. Cell Biol Int. 199418:617-28.

Rodan GA. Osteopontin overview. Ann N Y Acad Sci. 1995; 760:1-5.

Saito S, Shimizu N. Stimulatory effects of low-power laser irradiation on bone regeneration in midpalatal suture during expansion in the rat. $A m J$ Orthod Dentofacial Orthop. 1997; 111:525-32.

Sambrook J, Russell DW. Quantitative PCR. CSH Protoc. 2006; 2006(1): pii: pdb.prot3842.

Santiago HA, Zamarioli A, Sousa Neto MD, Volpon JB. Exposure to secondhand smoke impairs fracture healing in rats. Clin Orthop Relat Res. 2017; 475(3):894-902.

Sawada M, Shimizu N. Stimulation of bone formation in the expanding mid-palatal suture by transforming growth factor-beta 1 in the rat. Eur J Orthod. 1996; 18:169-79.

Shen Y, Liu HX, Ying XZ, Yang SZ, Nie PF, Cheng SW, Wang W, Cheng XJ, Peng L, $\mathrm{Xu} \mathrm{HZ}$. Dose-dependent effects of nicotine on proliferation and differentiation of human bone marrow stromal cells and the antagonistic action of vitamin $\mathrm{C}$. $J$ Cell Biochem. 2013; 114(8):1720-8.

Sherwin MA, Gastwirth CM. Detrimental effects of cigarette smoking on lower extremity wound healing. J Foot Surg. 1990; 29(1):84 -7.

Shintcovsk RL, Knop L, Tanaka OM, Maruo H. Nicotine effect on bone remodeling during orthodontic tooth movement: histological study in rats. Dental Press J Orthod. 2014; 19(2):96-107.

Silverstein P. Smoking and wound healing. Am J Med. 1992; 93 (1A):22S-24S.

Silva AP, Petri AD, Crippa GE, Stuani AS, Stuani AS, Rosa AL, et al. Effect of low level laser therapy after rapid maxillary expansion on proliferation and differentiation of osteoblastic cells. Lasers Med Sci. 2012; 27:777-83. 
Sodagar A, Donyavi Z, Arab S, Kharrazifard MJ. Effect of nicotine on orthodontic tooth movement in rats. Am J Orthod Dentofacial Orthop. 2011; 139(3):261-5.

Sodek J, Ganss B, Mckee MD. Osteopontin. Crit Rev Oral Biol Med. 2000; 11:279303.

Stampli MR, Anderson GP. How cigarette smoke skews immune responses to promote infection, lung disease and cancer. Nat Rev Immunol. 2009; 9:377-84,.

Tanabe N, Wheal BD, Kwon J, Chen HH, Shugg RP, Sims SM, Goldberg HA, Dixon SJ. Osteopontin signals through calcium and nuclear factor of activated $\mathrm{T}$ cells (NFAT) in osteoclasts: a novel RGD-dependent pathway promoting cell survival. $J$ Biol Chem. 2011; 286(46):39871-81.

Tanaka S, Matsuzaka K, Sato D, Inoue T. Characteristics of newly formed bone during guided bone regeneration: analysis of cbfa-1, osteocalcin, and VEGF expression. J Oral Implantol. 2007; 33:321-6.

Tanaka H, Tanabe N, Kawato T, Nakai K, Kariya T, Matsumoto S, Zhao N, Motohashi M, Maeno M. Nicotine affects boné resorption and suppresses the expression of cathepsin K, MMP-9 and vacuolar-type $\mathrm{H}(+)$-ATPase $\mathrm{d} 2$ and actin organization in osteoclasts. PLos One. 2013;8(3):e59402.

Takano-Yamamoto T, Takemura T, Kitamura Y, Nomura S. Site-specific expression of mRNAs for osteonectin, osteocalcin, and osteopontin revealed by in situ hybridization in rat periodontal ligament during physiological tooth movement. $J$ Histochem Cytochem. 1994; 42:885-96.

Terai K, Takano-Yamamoto T, Ohba Y, Hiura K, Sugimoto M, Sato M, Kawahata H, Inaguma N, Kitamura Y, Nomura S. Role of osteopontin in bone remodeling caused by mechanical stress. J Bone Miner Res. 1999; 14:839-49.

Tipton DA, Dabbous MK. Effects of nicotine on proliferation and extracellular matrix production of human gingival fibroblasts in vitro. J Periodontol. 1995; 66 (12):105664.

Wong PK, Christie JJ, Wark JD. The effects of smoking on bone health. Clin Sci. 2007; 113:233-41.

Zandi M, Miresmaeili A, Heidari A. Short-term skeletal and dental changes following bone-borne versus tooth-borne surgically assisted rapid maxillary expansion: A randomized clinical trial study. J Craniomaxillofac Surg. 2014; 22:1-6.

Zhou Z, Li B, Dong Z, Liu F, Zhang Y, Yu Y, Shang F, Wu L, Wang X, Jin Y. Nicotine deteriorates the osteogenic differentiation of periodontal ligament stem cells through a7 nicotinic acetylcholine receptor regulating Wnt pathway. PLoS One. 2013; 8(12):e83102. 

Anexos 

ANEXO A - Aprovação da Comissão de Ética no Uso de Animal.

\begin{tabular}{|c|c|}
\hline 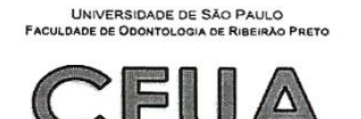 & UNIVERSIDADE dE SÃo PAULO \\
\hline COMISSAO DE & COMISSÃO dE ÉTICA NO USO DE ANIMAIS \\
\hline
\end{tabular}

\section{Certificado CeUA - FORP/USP}

Certificamos que o Protocolo $n^{\circ}$ 2014.1.492.58.8 sobre a pesquisa intitulada “Análise das proteínas ósseas liberadas após a aplicação de forças ortopédicas em ratos submetidos à inalação de fumaça de cigarro", sob a responsabilidade da Profa. Dra. Maria Bernadete Sasso Stuani, está de acordo com os Principios Éticos na Experimentação Animal adotados pela Comissão de Ética no Uso de Animais da Faculdade de Odontologia de Ribeirão Preto, USP, foi APROVADO em reunião da CEUA de 29/08/2014 (totalizando 60 animais).

We hereby certify that the protocol $n^{\circ} 2014.1 .492 .58 .8$ regarding the research entitled "Bone remodeling process evaluation after orthopedic forces application in rats submitted to cigarette smoke inhalation", under the responsibility of Profa. Dra. Maria Bernadete Sasso Stuani, is in accordance with the Ethical principles in animal research adopted by the Animal Research Ethics Committee of the School of Dentistry of Ribeirão Preto, University of São Paulo, Brazil, and was approved in 29/08/2014 (totalizing 60 animals).

Ribeirão Preto, 29 de agosto de 2014.

Profa. Dra. Andiara De Rossi Daldegan

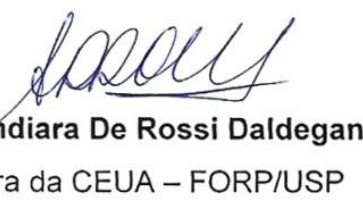

Coordenadora da CEUA - FORP/USP 
ANEXO B - Análise dos fenômenos histológicos.
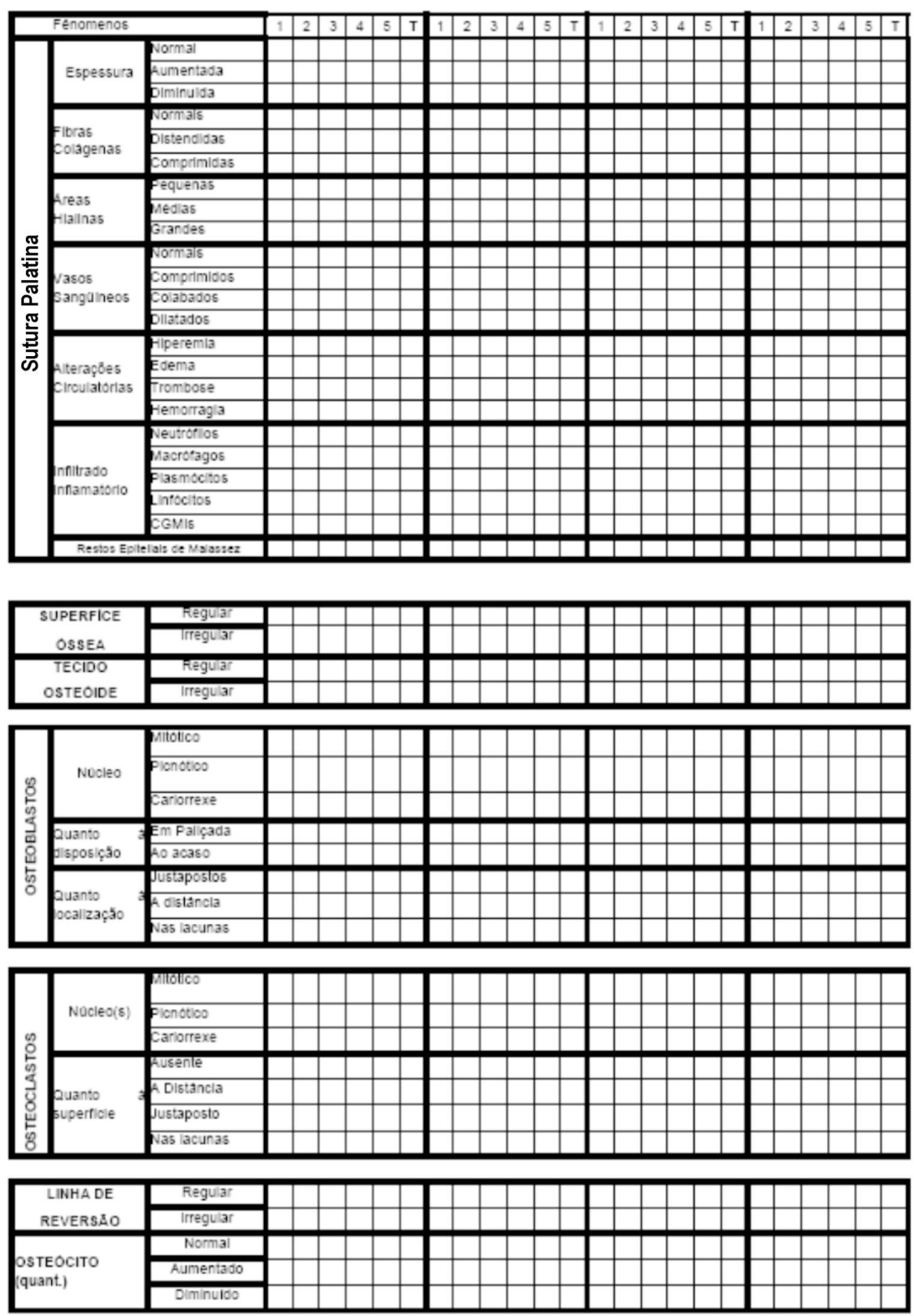